\title{
Atomic spectrometry update. Environmental analysis
}

Owen T. Butler, ${ }^{\mathrm{a} *}$ Jennifer M. Cook, ${ }^{\mathrm{b}}$ Christine M Davidson, ${ }^{\mathrm{c}}$ Chris F. Harrington, ${ }^{\mathrm{d}}$ and Douglas L. Miles ${ }^{\mathrm{b}}$

${ }^{a}$ Health and Safety Laboratory, Harpur Hill, Buxton, UK SK17 9JN

*owen.butler@hsl.gov.uk

${ }^{\mathrm{b}}$ British Geological Survey, Keyworth, Nottingham, UK NG12 5GG

${ }^{c}$ University of Strathclyde, Cathedral Street, Glasgow, UK G1 1XL

${ }^{\mathrm{d}}$ Nottingham Trent University, Clifton Campus, Nottingham, UK, NG11 8NS

This is the twenty-forth annual review published in JAAS of the application of atomic spectrometry to the chemical analysis of environmental samples. This Update refers to papers published approximately between September 2007 and August 2008. In the analysis of air, work is focused on the need to collect and characterise ultrafines, i.e. particles below $100 \mathrm{~nm}$ in size, and such research is being facilitated through the development of air sampler technologies for subsequent off-line analysis of particles and aerosol mass spectrometric techniques for real-time measurements. In the analysis of water elemental speciation and development of vapour generation techniques for metalloid species continue to attach attention. Data quality and metrological issues are receiving renewed interest in part due to an increase in water quality regulations. In the field of soil and plant analysis, elemental fraction and speciation protocols based upon sequential extraction procedures, chromatographic separation procedures and synchrotron radiation x-ray techniques continue to be utilized and developed. As noted in previous Updates, laser ablation continues to go from strength to strength in being adopted as a solid sampling tool in geochemical analysis. Work continues to be focused on the production, characterization and certification of new geological reference materials. Feedback on this review is most welcome and the lead author can be contacted using the email address provided. Alternatively, readers are welcome to complete the on-line questionnaire at http://www.asureviews.org. 
Air analysis

$1.1 \quad$ Review papers

1.2 Sampling techniques

Laboratory based measurements

1.3.1 Sample preparation

1.3.2 AAS, AFS and ICP based measurement techniques

1.3.2.1 Elemental analysis

1.3.2.2 Isotopic analysis

1.3.3 X-ray based measurement techniques

1.3.4 Other mass spectrometry based techniques

1.3.5 Other elemental measurement techniques

$1.4 \quad$ Field and on-line based measurements

1.4.1 AAS, AFS and AES based measurement techniques

1.4.2 X-ray based measurement techniques

1.4.3 Mass spectrometry based measurement techniques

1.4.4 Other elemental measurement techniques

2 Water analysis

2.1 Sample preparation

2.1.1 Sample collection, preservation and filtration procedures

2.1.2 Pre-concentration, extraction and separation procedures

$2.2 \quad$ Speciation

$2.3 \quad$ Instrumental analysis

2.3.1 Atomic emission spectrometry

2.3.2 Vapour generation methods

2.3.3 X-ray fluorescence spectrometry

2.3.4 Inductively coupled plasma mass spectrometry

2.3.5 Laser induced breakdown spectroscopy

$2.4 \quad$ Metrology and data quality

3 Analysis of soils, plants and related materials

3.1 Sample preparation 
3.1.1 Sample dissolution and extraction

3.1.2 Pre-concentration procedures

3.2 Speciation

$3.3 \quad$ Instrumental analysis

3.3.1 Atomic absorption spectrometry

3.3.2 Atomic emission spectrometry

3.3.3 Atomic fluorescence spectrometry

3.3.4 Mass spectrometry

3.3.4.1 Inductively coupled plasma mass spectrometry

3.3.4.2 Accelerator mass spectrometry

3.3.5 Laser-induced breakdown spectrometry

3.3.6 X-ray fluorescence spectrometry

$4 \quad$ Analysis of geological materials

$4.1 \quad$ Reference materials

4.2 Solid sample introduction

4.2.1 Laser ablation ICP-MS

4.2.2 Laser-induced breakdown spectroscopy

4.2.3 Slurry sampling

$4.3 \quad$ Sample treatment

4.3.1 Sample dissolution

4.3.2 Separation and preconcentration

4.3.3 Speciation studies

$4.4 \quad$ Instrumental analysis

4.4.1 Atomic absorption spectrometry

4.4.2 Atomic emission spectrometry

4.4.3 Inductively coupled plasma mass spectrometry

4.4.4 Other mass spectrometric techniques

4.4.5 X-ray techniques

5 Glossary of terms

$6 \quad$ References 


\section{$1 \quad$ Air analysis}

This section highlights noteworthy areas of research and development in the analysis of aerosols, particulates and gases by atomic spectrometric techniques that have been published since the last Update $^{1}$. It has been reorganized this year with measurement techniques being amalgamated into two sections: laboratory measurements where field samples are collected and returned to the laboratory for analysis and field and on-line measurements where both sampling and measurement are carried out in the field. Sample preparation and workup procedures associated with laboratory measurements are included in the relevant subsection. Preceding this laboratory measurement section is a section on sampling techniques describing advances and innovations in sampler design, performance testing and intercomparison of sampler designs.

\subsection{Review papers}

Chow and co-workers ${ }^{2}$ at the Desert Research Institute in the US provided an excellent and comprehensive review (323 references) on advances in integrated and continuous measurement of particle chemical composition, which is strongly recommended for those new to this field. They suggest that a key future topic will be the speciation of organic polar and nonpolar components in aerosol samples. Maenhaut ${ }^{3}$ from Ghent University in Belgium in an article (4 references) which considers future needs for global monitoring and research of aerosol chemical composition confirmed that measurements should focus on the organic component in aerosols. He advocates that air monitoring networks should be expanded to cover land masses in Africa, South America and Asia and that measurements above oceans are required. In addition, further tropospheric measurements are needed to understand the formation, sources and fate of aerosol components and their distribution in time and space over land masses and the oceans.

Turning to the metallic components of airborne particles, Wen and Carignan ${ }^{4}$ have reviewed (85 references) the emissions, the speciation and the fate of atmospheric Se. Smichowski ${ }^{5}$ summarizes (92 references) analytical methodologies for the determination of $\mathrm{Sb}$ in atmospheric aerosols and Shotyk and Le Roux ${ }^{6}$ provide an insight into biogeochemistry and cycling of $\mathrm{Pb}$ (209 references). European researchers present a review (13 references) on the current and future emissions of selected heavy metals to the atmosphere from anthropogenic 
sources in Europe showing the continuous reduction in heavy metals due to progress in developing efficient emission control equipment coupled with a more focused regulatory effort ${ }^{7}$. Several papers have been published on monitoring of emissions from engines including a comprehensive article (259 references) by $\mathrm{Maricq}^{8}$ on the chemical characterisation of particle emissions from diesel engines. Complementary reading to this review is a paper by Brazilian researchers on atomic spectrometric methods for the determination of metals and metalloids in automotive fuels ${ }^{9}$. Determination of PGEs in airborne particulates can be analytically challenging and two reviews ${ }^{10} 11$ provide up to date summaries of the performance and applicability of methods and instrumental techniques (101 and 91 references). In a review (182 references) of the determination of $\mathrm{Pu}$ and other transuranic elements by ICP-MS, Ketterer and Szechenyi $^{12}$ extol the advantages of SF-ICP-MS for the rapid and highly sensitive determination of these elements in environmental matrices. They reviewed work, which examined global fallout versus localised sources, e.g. Chernobyl and accidental nuclear weapon releases such as those that occurred in Palomares in Spain and Thule in Greenland, through measurement, in particular, of ${ }^{240} \mathrm{Pu} /{ }^{239} \mathrm{Pu}$ ratios in deposited/suspended particles.

Ortner $^{13}$, a leading exponent in his field, presents a comprehensive overview (54 references) of instrumental techniques for the speciation of elements in particulate samples. The relative merits of operationally defined sequential extractions, i.e. metal fractionation studies as applied to environmental matrices, including atmospheric-derived particles, are discussed by two research groups active in this arena ${ }^{14,15}$ (547 and 303 references).

\subsection{Sampling techniques}

The need to collect sufficient sample for analysis has led to developments in high volume air sampling techniques, as noted previously ${ }^{1}$. Returning to this theme, researchers in California have developed an in vitro electrostatic collector to collect ambient particles for toxicological studies $^{16}$. This design is a tandem of two technologies: a patented versatile aerosol concentration enrichment system (VACES) and a newly developed electrostatic precipitator (ESP). Sample air is drawn over a pool of warm distilled water, to achieve saturation of the particles, and then subsequently passed through a condenser that allows the fine/ultrafine particles to grow to about $\sim 3 \mu \mathrm{m}$. The particles are then passed through two virtual impactors to increase particle concentration, i.e. particles are concentrated from a $2001 \mathrm{~min}^{-1}$ air stream into a $1.81 \mathrm{~min}^{-1}$ air stream. Particles are then drawn through a diffusion drier that removes the excess water and 
returns the particles to their original sizes. The concentrated particles are passed through an electrostatic precipitator at this nominal $1.81 \mathrm{~min}^{-1}$. For sampling particles, in excess of $1.5 \mu \mathrm{m}$, only the virtual impactor segment of this system is used in conjunction with the ESP. Samples are collected onto petri dishes containing cell cultures. The optimised system was shown to collect particles with efficiency in excess of $95 \%$ across the range $18 \mathrm{~nm}$ to $3.0 \mu \mathrm{m}$ and particle losses within the ESP were found to be negligible $(<1 \%)$. The design of the ESP using twin metal needles to facilitate a corona discharge resulted in a high particle charging efficiency with little ozone production. The advantages of the preconcentration unit are that sampling durations can be reduced, not only to examine short-term exposure incidences but also to assist in maintaining the viability of the cell culture substrate during the sampling period.

Electric-mobility particle analyzers are commonly used to meet a growing need to study spatial and temporal variation of particles, especially sub-micron ones, not only in the ambient environment but in the workplace, where there is growing potential for exposure to engineered nanoparticles. Such systems consist of three sections: a particle charger, an electrical mobility separator to size particles and a detection system to measure the concentration of the sized particles. Commercially available systems tend to be large, complex and relatively expensive and are often most suited for research projects operating under laboratory conditions. Hence research into compact, robust and more portable particle-sizing equipment is being undertaken. American researchers describe the development of their prototype miniature electrical mobility aerosol spectrometer so-called $\mathrm{MEAS}^{17}$. With this system, electrostatic precipitation is used for both generation of sheath flow and subsequent classification of particles based upon their electrical mobility. Initial laboratory work focused on testing the ESP and classifier sections; the measurements were seen to closely match theoretical models. Size distribution measurements of laboratory generated aerosols and field sampling conducted at an engine emissions test bed compared favourably with results from larger, commercial sizing instruments such as a scanning mobility particle sizer (SMPS). Although further work is required, e.g. the current system does not possess an upstream impactor to remove larger particles, nevertheless the authors see potential for a compact device that could be used for personal and large scale monitoring campaigns. Another American research group have developed their own version of a low cost miniature disk-type electrostatic precipitator for a personal nanoparticle sizer ${ }^{18}$. They focused on the laboratory evaluation of the precipitator's performance as an electrostatic aerosol classifier; a 
commercially available ultrafine condensation particle counter was used to count particle numbers.

American researchers coupled a VACES system, described above, to a nanoMOUDI (Nano-Micro Orifice Uniform Deposit Impactor) to collect and enrich size-segregated ambient aerosol samples at a roadside location for subsequent elemental analysis by ICP-MS ${ }^{19}$ The VACES system concentrated particles from an inlet flow of $2001 \mathrm{~min}^{-1}$ into a flow stream of $11.51 \mathrm{~min}^{-1}$. Ten litres per minute was passed through the nanoMOUDI which classified particles, via impaction, into the following size ranges: $2.5-0.18 \mu \mathrm{m} ; 0.18-0.10 \mu \mathrm{m} ; 0.10-$ $0.056 \mu \mathrm{m} ; 0.056-0.032 \mu \mathrm{m}$ and $0.032-0.018 \mu \mathrm{m}$. The remaining $1.51 \mathrm{~min}^{-1}$ airflow was passed through a SMPS to obtain real-time particle sizing information. Data obtained from this tandem system compared well with data from individually collocated SMPS and MOUDI samplers. As the concentration of metals in air is often in the low $\mathrm{ng} \mathrm{m}^{-3}$ range or below, it can be assumed that concentrator systems will be used increasingly to provide sufficient particle mass for analysis for short duration sampling campaigns where highly time-resolved data are required.

Personal samplers for micron-sized particles are being developed, based upon impaction theory. An international consortium has described the laboratory and field testing of a novel three-stage personal dust sampler for sampling three dust fractions simultaneously ${ }^{20}$. These dust fractions, familiar to occupational hygienists, are those proposed jointly by ISO/CEN/ACGIH, namely: the inhalable fraction (IF: $0-100 \mu \mathrm{m}$ ); the thoracic fraction (TF: $0-30 \mu \mathrm{m})$ and the respirable fraction (RF: $0-10 \mu \mathrm{m}$ ). In layman's terms IF equates to the fraction of dust that enters the nose and mouth, TF equates to the fraction that reaches the thorax or chest and RF equates to the fraction that reaches the lungs and the gaseous exchange regions. This sampler design showed that, at a nominal $3.21 \mathrm{~min}^{-1}$, the sampling efficiency curves matched the ISO/CEN/ACGIH thoracic and respirable sampling criteria. Three polyurethane foam (PUF) impaction stages and an after-filter were used for size selection. For the IF, the sampler showed a reasonable agreement with the inhalable convention but it was noted that the sampler increasingly under sampled for particles greater than $15 \mu \mathrm{m}$. Improvements to design a better inlet to reduce this discrepancy are in progress. As PUF materials can readily absorb water, gravimetric analysis must be conducted under controlled conditions with closely defined temperature and humidity. Precision of weighing was estimated to be $5 \mu \mathrm{g}$. Future initiatives using PUF substrates will require the development of robust sample preparation procedures for 
subsequent chemical analysis as there is a growing need to measure chemical constituents in particles rather than just relying on measurements of mass.

In a similar vein, American researchers have developed a personal sampler to evaluate an individual's exposure to ambient coarse particle matter, the so-called $\mathrm{PM}_{10-2.5}$ fraction ${ }^{21}$. Historically such material has been defined as particles smaller than $10 \mu \mathrm{m}$ but greater than 2.5 $\mu \mathrm{m}$. Little is known about personal exposure to this range of particle sizes, in part due to the lack of commercially available portable samplers with the ability to sample concurrently both this particle size range and the $<\mathrm{PM}_{2.5}$ fraction. This new sampler operates at a nominal $51 \mathrm{~min}^{-1}$, a flow rate that is compatible with available portable pump and battery technologies. Polyurethane foam, with defined pore sizes, is used in the impactions stages to sample the $\mathrm{PM}_{10+}$ and $\mathrm{PM}_{10-2.5}$ particle fractions, whilst a $0.2 \mu \mathrm{m}$ filter is used to collect the $\mathrm{PM}_{2.5}$ fraction. The weighing precisions, under controlled conditions, were similar to those mentioned in the previous study ${ }^{20}$. The performance of this sampler was evaluated by co-location studies in the field involving an US EPA approved reference sampler; the mass agreement between the two samplers was found to be better than $20 \%$.

The Interagency Monitoring of Protected Visual Environments (IMPROVE) is a cooperative measurement study in the US designed to characterise current visibility and aerosol conditions in National Parks and Forests and to identify chemical species and emissions that impair visibility. In 2003, this network began operating co-located samplers at several sites to assess the precision of aerosol measurements. Hyslop and White ${ }^{22}$ present precision data calculated using US EPA guidelines. They found that only 6 of the 41 measurands on the colocated filter samples had precisions $<10 \%$. These were $\mathrm{PM}_{10}$ and $\mathrm{PM}_{2.5}$ content (by gravimetric analysis), hydrogen content (by PESA analysis), $\mathrm{S}$ and $\mathrm{Br}$ content (by XRF analysis) and sulphate content (by IC). Co-located precision, not surprisingly, tended to improve with increasing frequency of analyte concentration determined above analytical detection limits and where the analyte species was predominately in smaller particle size fractions. Precision tended to improve where the analysis was performed on the whole filter rather than on a fraction of the filter, suggesting that the spatial distribution of analytes on the filter may be an issue. Interestingly, for most of the analytes studied, the precisions measured were inferior to the precisions calculated using a 'bottom up' measurement uncertainty budget. This suggests that some sources of uncertainty were not being accounted for or that they have been underestimated. 
A US research consortium has investigated variability in results obtained between different measurement systems where different sampler designs were used ${ }^{23}$ They compared the performance of three widely used samplers: the MetOne Speciation Air Sampler; the Thermo Reference Ambient Air Sampler and the Desert Research Institute (DRI) Sequential Air Sampling System. All three systems allow multiple samples to be collected in parallel, thus facilitating the measurement of a wide range of inorganic and organic components in ambient air. As in the paper by Hyslop and White ${ }^{22}$, there was good correlation between the results obtained for $\mathrm{PM}_{2.5}$ mass, ammonium ion, sulphate ion, organic carbon and total carbon submitted from the two test houses that analysed the resultant filters. Both laboratories are accredited for such analysis and possess considerable experience in the analysis of air samples. The results for elemental carbon however did not compare well, but this was attributed to the different operationally defined analytical protocols used in the two laboratories to measure this species. Despite being highly correlated, it was found that the DRI sampler reported $\mathrm{PM}_{2.5}$ masses that were lower by $13-18 \%$ compared to masses sampled using the other two samplers. It was suggested that this bias may be due to loss of volatile species from filter samples arising from differences in sampler air flow velocities across filters and differences in duration that filters remained in the samplers in the field after sampling and before collection.

Researchers at the University of Iowa have revisited a method of passive sampling to collect ambient $\mathrm{PM}_{10-2.5}{ }^{24}$. It involves the deposition of particles onto precleaned glass cover slips mounted on an SEM stub assembly. Light microscopy combined with digital imagery is then used to determine particle surface loadings by size and, through a number of computations, back to the original airborne concentrations. Laboratory tests, within a wind tunnel, and field tests were carried out to validate the computational model. Sampling was conducted using a colocated pumped reference $\mathrm{PM}_{10-2.5}$ air sampler. Coarse $\left(\mathrm{PM}_{10-2.5}\right)$ particles measured with the passive sampler were biased positive to the results from the reference air sampler by some $28 \%$ although regression analysis showed that the two data sets were highly correlated, suggesting that this bias is systematic. The authors suggest that this bias may be attributable to assumptions made in calculating mass concentrations from the passive sampler, such as those arising from estimations of particle size densities or dynamic shape factors. Improved estimates for particle densities could be derived from chemical speciation information or the use of site-specific correction factors obtained using co-location studies, to adjust the results from passive samplers. The limit of detection was calculated to be $2.3 \mu \mathrm{g} \mathrm{m}^{-3}$ for a 5-day sample. A bootstrap statistical 
analysis suggests that at least 300 particles need to be imaged by the microscopic technique to stabilise the analytical variability of the method.

British workers employed filter pack samplers, using alkali-impregnated filters, to investigate the $\mathrm{S}$ and $\mathrm{O}$ isotope systematics of $\mathrm{SO}_{2}$ and sulphate particles emitted from volcanic vents for the first time ${ }^{25}$. Field data suggest that fractionation of $\mathrm{S}$ isotopes occurs during the collection of $\mathrm{SO}_{2}$ from concentrated volcanic gas plumes. The co-collection of hydrochloric acid vapour on the same filters may play a role in this fractionation through the revolatilisation of the weaker acid by the absorption of the stronger acid on the filter. This fractionation only became significant when elevated filter loadings occurred. Minimising the filter loading, i.e. shortening the sampling duration, reduced this effect but there is a requirement to collect sufficient sample mass for the highly precise isotopic analysis. Despite the ease of use of such filter packs in such remote and harsh environments, this fractionation effect limits their use for the determination of $\delta^{34} \mathrm{~S}$ for $\mathrm{SO}_{2}$ in volcanic gases. It was possible to obtain some meaningful data by determining $\delta^{34} \mathrm{~S}$ values via extrapolation back to zero loading on a filter through the analysis of filter samples with different mass loadings. A companion paper describes in detail the work carried out on sulphate particle species where it was found that the $\mathrm{O}$ isotopic composition varied but that the isotopic composition of $\mathrm{S}$ did not ${ }^{26}$. Artefact sulphate formation from oxidation of $\mathrm{SO}_{2}$ is suggested as a plausible explanation for this. The authors suggest that studies under laboratory conditions will be needed to elucidate possible mechanisms for such fractionation processes.

Korean researchers determined mercury emissions from automobiles using gasoline, diesel and LPG fuel. ${ }^{27}$. An in-situ sampling system was constructed based upon the Ontario Hydro impinger sampler originally developed for $\mathrm{Hg}$ emissions from coal-fired power stations. A vehicle battery provided power to the system using an invertor to convert direct current to alternating current. Emissions from the tailpipe were fed via a heated probe through a heated filter, to collect particulate $\mathrm{Hg}\left(\mathrm{Hg}^{\mathrm{P}}\right)$, then through a series of eight chilled impingers. Divalent $\mathrm{Hg}\left(\mathrm{Hg}^{\mathrm{II}}\right)$ is collected in the first three impingers which contain an aqueous $\mathrm{KCl}$ solution. Elemental $\mathrm{Hg}\left(\mathrm{Hg}^{0}\right)$ is then collected in the next four impingers which contain $\mathrm{H}_{2} \mathrm{O}_{2} / \mathrm{HNO}_{3}$ or $\mathrm{KMnO}_{4} / \mathrm{H}_{2} \mathrm{SO}_{4}$ trapping solutions. Samples were subsequently analysed in the laboratory using CVAAS. The mercury detected in exhaust gases was found to be essentially $\mathrm{Hg}^{0}$. At idling modes, $\mathrm{Hg}$ concentrations in the exhaust gases of petrol, diesel and LPG vehicles were 1.5 - 9.1, $1.6-3.5$ and $10.2-18.6 \mathrm{ng} \mathrm{m}^{-3}$ respectively. At driving modes, these concentrations rose to $3.8-$ $16.8,2.8-8.5$ and $20.0-26.9 \mathrm{ng} \mathrm{m}^{-3}$ respectively. Corresponding emissions rates calculated for 
idling conditions were $0.07-0.4 \mu \mathrm{g} \mathrm{hr}^{-1}, 0.1-0.2 \mu \mathrm{g} \mathrm{hr}^{-1}$ and $0.7-1.3 \mu \mathrm{g} \mathrm{hr}^{-1}$ for petrol, diesel and LPG respectively. At driving modes the values were calculated to be $0.6-2.5 \mu \mathrm{g} \mathrm{hr}^{-1}, 0.7-$ $1.9 \mu \mathrm{ghr}^{-1}$ and $4.5-6.1 \mu \mathrm{g} \mathrm{hr}^{-1}$.

Sampling harsh environments can be difficult. Agrawal et al. ${ }^{28}$ present the first on-wing investigation of the chemical characterisation of commercial aircraft jet engine emissions. Their sampling system allows air samples to be collected from the plume of a turbofan engine exhaust through a probe and directed to the sampling system. The heated transfer lines used were constructed from stainless steel and a $\mathrm{PM}_{2.5}$ impactor was used to remove potential large particles. The sampling system consisted of a manifold, operating with solenoid valves under computer control, which directed sample flow, in sequence, to an appropriate sampling medium, be it a filter, sorbent tube, PUF cartridge or a SUMMA ${ }^{\mathrm{TM}}$ canister. In conjunction with a highvolume flow rate, this fast switching system allowed a wide range of both inorganic and organic analytes to be sampled in the limited period of time allocated for each engine test run. Analysis showed that emission rates are highly dependant on power output. Hydrocarbon emissions are most significant at idling conditions whereas particulate matter emissions are found to be most significant at higher power outputs associated with take-off and landing. Sheya et al. ${ }^{29}$ investigated the performance of two stack sampling methodologies for fine metal particle characterisation from hot ferrous metal casting processes. The widely used hot filter/cold impinger train, based upon US EPA methods 201A and 202, was compared with results obtained using a dilution sampling similar to that described in US EPA conditional method 039. The filter/impinger sampling system uses cyclonic samplers to sample $\mathrm{PM}_{10}$ and $\mathrm{PM}_{2.5}$ particles and the filter assembly is heated to prevent sample condensation. Gaseous species that pass through the filter are subsequently collected in a series of four impingers that contain chilled water. The dilution sampler system, on the other hand, draws 20-25 $1 \mathrm{~min}^{-1}$ of sample from the stack effluent through a venturi flow meter and mixes this sample stream with a stream of ambient air previously scrubbed by passing through a HEPA filter and an activated carbon bed trap. This diluted and mixed gas stream is subsequently drawn into an 'aging' chamber from whence samples are collected using cyclonic samplers/filter packs for off-line chemical characterisation. It was found that $\mathrm{PM}_{2.5}$ emissions for the entire casting process examined ranged from $3.4-4.7$ $\mathrm{lb} / \mathrm{t}$ of metal processed when using the filter/impinger sampling system but $0.8-1.8 \mathrm{lb} / \mathrm{t}$ when using the dilution chamber sampling approach. As the filter/impinger sampling approach is used 
worldwide for regulatory compliance monitoring, further work is clearly required to reconcile such differences.

\subsection{Laboratory based measurements}

\subsubsection{Sample preparation}

Closed vessel microwave-assisted digestion procedures have become widely accepted for the dissolution of air particulates due to their efficiency of attack and the ability to prepare samples under clean conditions. American researchers have developed a procedure for the determination of trace elements, including REEs, in atmospheric fine particulate matter ${ }^{30}$. A $\mathrm{HNO}_{3} / \mathrm{HF}$ acid mixture was employed, and $\mathrm{H}_{3} \mathrm{BO}_{3}$ was subsequently added to complex excess fluoride and to redissolve fluoride-containing precipitates. Recoveries were adjudged to be quantitative for some 30 elements based on the analysis of NIST SRMs 1648 and 2783. Italian researchers developed a high throughput microwave-assisted digestion protocol for a range of environmental matrices ${ }^{31}$. Screw cap disposable polystyrene test tubes were used as digestion vessels. This paper will be of interest to researchers using biomonitoring samples such as leaves and lichens to assess levels of particulate fallout from the atmosphere, as they included CRMs such as BCR 62 (olive leaves), BCR 100 (beech leaves) and BCR 482 (lichen) in their study. Good agreement was noted against certified values for many elements but significant deviations were noted for $\mathrm{Ca}, \mathrm{Cr}, \mathrm{Fe}$ and $\mathrm{Hg}$. The authors suggest that this procedure offers a low contamination, low cost and high throughput approach to preparing large quantities of samples often associated with typical biomonitoring surveys.

Risk of contamination during air sampling, handling of filters and their subsequent

analysis is a theme addressed by Rasmussen et $a l^{32}$. They concluded that, depending upon the element, the contribution from contamination commonly exceeds the content of airborne particles being sampled. This is exacerbated when a low volume of air has been sampled, e.g. by personal air monitors, or when the airborne concentrations of metals are generally low. They suggest that personal air samplers should be assembled within the confines of a clean air bench to reduce field blank values. It was suggested that at least $10 \%$ of the total number of filter analysed should be field blank filters so that a robust estimation of blank levels can be made. Alternatively, if possible, the sample volume should be increased to minimise the effect of any blanks. 
New certified reference materials prepared by NMI over the last couple of years have now been released. NIST have blended, bottled and certified a new batch of SRM 1648 Urban particulate matter and it is currently available as SRM 1648a (see www.nist.gov). It is certified for 24 elements, provides reference values for a further 8 elements and includes indicative values for 6 more elements. SRM 1648a has been prepared from the same dust material used to prepare SRM 1648 so most of the values are statistically similar to those supplied with the original certification. Homogeneity testing shows that this material can now be used at a nominal $5 \mathrm{mg}$ aliquot reflecting more closely typical masses collected on air filter samples. The original NIST SRM 1648 material was certified at a nominal $100 \mathrm{mg}$. A disadvantage is that, as a result of using feedstock material dating from the seventies, the concentrations of certain elements such as $\mathrm{Pb}$ are atypical of those found today. Nevertheless this new material is most welcome in a measurement field where few reference materials exist. In a similar vein, researchers at NIES in Japan, alongside Chinese co-workers, have produced CRM 28 Urban aerosols, a particulate material collected between 1995 and 2005 from the ventilation system in a building in Beijing ${ }^{33}$. The recommended minimum sample aliquot for analysis is $20 \mathrm{mg}$. This material is certified for 18 elements and reference values are supplied for a further 14 elements. For those interested in monitoring Be exposure in workplaces, NIST 1877, a $\mathrm{BeO}$ material, has been released (see ww.nist.gov). At IRMM, researchers are developing procedures for the preparation of Ucontaining reference material particles using certified $U_{F}$ precursors ${ }^{34}$. Their aim is to prepare $U$ particles with certified isotopic abundances that are representative of those found in $U$ enrichment facilities and thus assist in the quality assurance of environmental measurements carried out as part of future international nuclear inspection programmes.

Fraction studies involving sequential extraction procedures continue to attract interest. Canadian researchers have suggested improvements to the well-known Zatka sequential leaching procedure for the fractionation of nickel-containing particles found in the workplace air within nickel refining plants ${ }^{35}$. Noel et al. ${ }^{36}$ evaluated a six-stage leach procedure for determining $\mathrm{Hg}$ binding mechanisms to coal combustion byproducts. Czech researchers applied a modified BCR three-step sequential extraction procedure to urban dust samples to determine fractionation profiles for $\mathrm{As}, \mathrm{Cd}, \mathrm{Cr}, \mathrm{Mn}, \mathrm{Ni}$ and $\mathrm{Pb}^{37}$. A similar procedure was used by researchers from Argentina ${ }^{38}$ to determine fractionation profiles in ambient $\mathrm{PM}_{10}$ particles collected on filter samples. Extraction procedures on airborne particulate matter involving organic solvents within a 
pressurised solvent extraction system $^{39}$ and bioavailability testing involving synthetic gastric juices ${ }^{40}$ have also been reported.

Researchers at the University of Wisconsin have developed a Mn speciation method for atmospheric aerosols ${ }^{41}$. A $\mathrm{PM}_{2.5}$ sampler that could collect 8 filters simultaneously was used to collect the test samples. Some of these filter samples were analysed for total Mn by SF-ICP-MS following closed vessel microwave-assisted digestion. Two spectrophotometric methods were optimised and used to determine total soluble $\mathrm{Mn}$ and soluble oxidised $\mathrm{Mn}$, i.e. $\mathrm{Mn}^{\mathrm{III}}$ and $\mathrm{Mn}^{\mathrm{IV}}$ species leached from other selected filter samples. Four biologically and environmentally relevant fluids were examined as potential leach solutions and it was found that an acetatebuffered solution, mimicking rain water, gave the highest extraction values for soluble Mn. Soluble Mn accounted for some $6-20 \%$ of the total Mn determined in filter samples collected in East St. Louis, Illinois, but oxidised Mn species were not detected. In contrast, some 40\% of total $\mathrm{Mn}$ in air particulate samples collected in Toronto was determined as soluble Mn of which roughly a third was determined to be an oxidised Mn species. Total soluble Mn levels nevertheless were similar in both cities. As oxidised Mn species were not found in the corresponding $\mathrm{PM}_{10}$ fraction in air samples collected in Toronto, it was felt that this ruled out soil particles as a possible source of oxidised Mn species. The conclusion was that soluble $\mathrm{Mn}$ found in $\mathrm{PM}_{2.5}$ fraction in air samples from Toronto was therefore combustion related. As no significant $\mathrm{Mn}$ emission point source was identified in the greater Toronto region, it was suggested that the source may be the combustion of the manganese-based fuel additive, methylcyclopentadienyl manganese tricarbonyl.

\subsubsection{AAS, AFS and ICP based measurement techniques}

\subsubsection{Elemental analysis}

Atomic spectrometric methods such as AAS and ICP are now well established for the measurement of elemental species in aerosols collected through filtration sampling. Whilst AAS and ICP-AES continue to be used for the analysis of samples derived from the atmosphere, ICP$M S$ is now starting to dominate this measurement arena and it is interesting to note the use of $\mathrm{DRC}^{42}$ and collision cell ${ }^{43}$ instruments to remove polyatomic species that can cause isobaric overlaps on key elements such as As, $\mathrm{Cr}$ and $\mathrm{V}$.

As suggested by Rasmussen et al. ${ }^{32}$, analysis by ICP-MS may become blank-limited in the future. For this reason, direct filter analysis by XRF techniques and/or procedures involving 
little or no sample dissolution step are becoming increasingly attractive. Chinese researchers have continued to develop their slurry sampling ETV-ICP-MS approach, described in detail in last year's Update ${ }^{1}$, for the determination of REEs in coal fly ash and atmospheric particulates ${ }^{44}$. Japanese researchers are developing a simple and rapid analytical method for monitoring the enrichment of sub-micron particles in heavy metals emissions in flue gases from incinerators ${ }^{45}$. An Electrical Low Pressure Impactor (ELPI) was used which, in addition to providing real-time information on the size distribution of aerosol particles in the range 0.03 to $10 \mu \mathrm{m}$, allows sampled particles to be collected on impaction plates for subsequent off-line analysis. These researchers are proposing to use LIBS as a direct analysis technique. Simulated calibration standards were prepared by evaporating elemental solutions onto ELPI impaction plates similar to those proposed for sampling flue gases. A similar system is in use in this author's laboratory to assist in the characterisation of workplace dusts. Here, in contrast, we employ off-line microwave digestion and ICP-MS with a high efficiency nebuliser. Further developments are awaited with interest and it would be useful to see research into other direct on filter measurement techniques such as LA-ICP-MS or TXRF. Fundamental studies and applications into the potential use of LIBS as an on-line technique are described below.

Whilst new developments have been scare, elemental analysis of airborne particles by atomic spectrometric techniques remains popular. Deposition analysis has included the analysis of ice/snow cores ${ }^{46,47}$, lichens ${ }^{48}$, mosses ${ }^{49}$,rainwater $^{50,51}$ tree bark $^{48,52-54}$ and leaves ${ }^{55}$ as a means of assessing current and historical metallic particulate loading in the atmosphere. Comparative or complementary analysis using X-ray ${ }^{56}$ or nuclear techniques ${ }^{48,49,52,55}$ have also been performed. Klos et al. $^{57}$ issue a note of caution about the use of such media for monitoring deposition and the potential for unidentified pollution sources nearby to confound deposition data. In a study involving the analysis of moss and soil samples in a forest as a proxy for regional particulate deposition, they noted a false positive bias due to ash spilt on nearby forest roads. .

One eye-catching study was that by Taiwanese researchers ${ }^{58}$ who investigated the accumulation of trace elements, used in the semiconductor industry, in Formosan squirrels! Taiwan is a country with a large electronics-manufacturing base. High concentrations of elements such as As, Cd, Ga, In and $\mathrm{Tl}$ were determined in liver, lung, kidney and muscle samples from these unfortunate animals. The Ga/As ratios determined in lung samples from wild animals resembled those of animals after intratracheal administration of particulate gallium arsenide. 
Measurement of PGEs in ambient air particles continues to attract attention due to the growth in automobiles equipped with catalytic convertors. South American workers analysed exhaust fume captured directly from tailpipes onto filters and found levels of up to 5.4, 12.6 and $1.0 \mathrm{mg} / \mathrm{kg}$ of $\mathrm{Pd}, \mathrm{Pt}$ and $\mathrm{Rh}$ respectively in exhaust dust from cars equipped with the most up to date catalytic convertors ${ }^{59}$. Italian researchers have measured environmental levels of Ir emitted from the latest generation of catalytic convertors by SF-ICP-MS. Airborne concentrations of 1.4 $\pm 1.6 \mathrm{pg} \mathrm{m}^{-3}, 0.4 \pm 03 \mathrm{pg} \mathrm{m}^{-3}$ and $0.4 \pm 03 \mathrm{pg} \mathrm{m}^{-3}$ in TSP, $\mathrm{PM}_{10}$ and $\mathrm{PM}_{2.5}$ particle size fractions respectively were determined ${ }^{60}$. German researchers, using a nickel sulphide fire assay sample preparation method in conjunction with ICP-MS, have determined levels of Pd, Pt and Rh in both road dust samples and in airborne dust samples ${ }^{61}$. Their results, for samples collected in 2005 at a site with heavy traffic, revealed airborne levels of $38 \mathrm{pg} \mathrm{m}^{-3}$ for $\mathrm{Pd}, 159 \mathrm{pg} \mathrm{m}^{-3}$ for $\mathrm{Pt}$ and $10 \mathrm{pg} \mathrm{m}^{-3}$ for $\mathrm{Rh}$. The levels recorded in the corresponding road dust samples were 38 $\mathrm{mg} / \mathrm{kg}, 1730 \mathrm{mg} / \mathrm{kg}$ and $110 \mathrm{mg} / \mathrm{kg}$ respectively. When compared to a previous $1999 \mathrm{study}$, the PGE concentrations were found to have increased by a factor of 2 to 9 fold. Sutherland et al. ${ }^{62}$ collected road-side dust samples of $<63 \mu \mathrm{m}$ and a further five fractions between 63 and 2000 $\mu \mathrm{m}$. Concentrations in the $<63 \mu \mathrm{m}$ fraction reached $101 \mathrm{mg} / \mathrm{kg}, 174 \mathrm{mg} / \mathrm{kg}$ and $16 \mathrm{mg} / \mathrm{kg}$ for Pd, $\mathrm{Pt}$ and $\mathrm{Rh}$ respectively. Size partitioning indicated that this $<63 \mu \mathrm{m}$ fraction had the lowest PGE concentrations and mass loadings percentages. This indicates that PGE fluxes derived from autocatalyst emissions into the wider environment are significantly underestimated if only a fine grain size fraction is analysed. Austrian researchers confirmed that the major part of Pd and Pt emissions were released in a coarser aerosol mode, i.e. a size fraction $>\mathrm{PM}_{10}$ but nevertheless noted that a considerable amount, $22 \%$ for $\mathrm{Pd}$ and $12 \%$ for $\mathrm{Pt}$, was emitted in the respirable $\mathrm{PM}_{2.5}$ size fraction ${ }^{63}$.

Measurement of mercury in the atmosphere continues to attract interest. Previous Updates have summarised developments in the measurement of $\mathrm{Hg}$ in flue gas mercury and in the deployment of automated systems to measure $\mathrm{Hg}$ species in ambient air. There is growing interest in measuring $\mathrm{Hg}$ emissions from transport, and hence measurements in fuel and associated feedstock. Thus, Won et al. ${ }^{27}$, in addition to measuring Hg emissions from automobile tailpipes, determined Hg concentrations in typical Korean petrol, diesel and LPG supplies. A liquid-liquid extraction procedure involving $\mathrm{BrCl}$ was used to extract $\mathrm{Hg}$ species into an aqueous phase, which was then analysed by CV-AAS. The LPG samples were collected by passing the gas sample through an impinger and analysing in a similar fashion to the petrol and diesel 
samples. Typical Hg concentrations were $571 \mathrm{ng} \mathrm{L}^{-1}$ for petrol, $186 \mathrm{ng} \mathrm{L}^{-1}$ for diesel and $1230 \mathrm{ng}$ $\mathrm{L}^{-1}$ for LPG. Similarly, Landis et $a l .{ }^{64}$ determined mercury concentrations in US petrol and diesel supplies using the more sensitive Tekhran gold trap CV-AFS system for analysis. The Hg content of various grades of petrol was $284 \pm 108 \mathrm{ng} \mathrm{L}^{-1}$ and $62 \pm 37 \mathrm{ng} \mathrm{L}^{-1}$ in diesel supplies. They also determined tail-pipe emissions within the vicinity of a road tunnel system in Baltimore which had dedicated tunnels for light and heavy duty vehicles, i.e. petrol cars and diesel trucks. Averages airborne levels determined during this study were $2.4 \mathrm{ng} \mathrm{m} \mathrm{m}^{-3}\left(\mathrm{Hg}^{0}\right), 17 \mathrm{pg} \mathrm{m}^{-3}\left(\mathrm{Hg}^{2+}\right)$ and $54 \mathrm{pg} \mathrm{m}^{-3}\left(\mathrm{Hg}^{\mathrm{P}}\right)$. Rutter et al. $^{65}$ describe an off-line sampling method to determine $\mathrm{Hg}$ species in air. Quartz fibre filters and quartz fibre filters coated with $\mathrm{KCl}$ sorbent mounted in series within a Teflon filter holder were used to collect $\mathrm{Hg}^{\mathrm{p}}$ and $\mathrm{Hg}^{2+}$ species respectively. A Teflon-coated aluminium $\mathrm{PM}_{2.5}$ cyclonic inlet was used to remove large particles. Back in the laboratory, a home-made thermal desorption system was used to liberate from the filter samples $\mathrm{Hg}$ species which were converted to $\mathrm{Hg}^{0}$ prior to analysis by gold trap CV-AFS. This system had a number of discrete modules: a scrubber to provide $\mathrm{Hg}$-free argon carrier gas; a sample furnace

to thermally release the $\mathrm{Hg}$ species; a pyrolyser to convert residual $\mathrm{Hg}^{2+}$ species to $\mathrm{Hg}^{0}$; a purification trap to remove water and free halogens and organics through the use of soda lime and tenax traps; a gold trap to preconcentrate $\mathrm{Hg}^{0}$ and a Tekhran CV-AFS analyser module. Calibration was carried out with $\mathrm{Hg}^{0}$ gas standard and performance verified through analysis of CRMs containing $\mathrm{Hg}^{\mathrm{P}}$ and filters spiked with $\mathrm{HgCl}_{2}$ solutions. Laboratory system blanks were $0.3 \pm 0.2 \mathrm{pg} \mathrm{m}^{-3}$ for both $\mathrm{Hg}^{\mathrm{p}}$ and $\mathrm{Hg}^{2+}$ species rising to $0.9 \pm 0.2 \mathrm{pg} \mathrm{m}^{-3}$ and $3.5 \pm 3.5 \mathrm{pg} \mathrm{m}^{-3}$ respectively for field filter blanks. Field-testing carried out in parallel with an automated Tekhran speciation instrument showed that $\mathrm{Hg}^{2+}$ results were comparable. Measurement of $\mathrm{Hg}^{\mathrm{p}}$ by the off-line instrument however revealed a factor of 2.7 difference between the systems. There is a suggestion that evaporative losses of $\mathrm{Hg}^{\mathrm{P}}$ within the automated system prior to the analysis step may be a cause although further investigations are needed.

\subsubsection{Isotopic analysis}

Researchers from the Woods Hole Oceanographic Institute have published a method for determining the $\mathrm{Br}$ isotopic content of brominated organic compounds(BOCs) ${ }^{66}$. To measure $\mathrm{Br}^{81} / \mathrm{Br}^{79}$ in BOCs, they coupled a GC system to a multicollector ICP-MS system. Spectra were examined for potential contributions from $\mathrm{ArArH}^{+}$and solvent peaks but these were found to be 
negligible. The analysis of three brominated benzene materials showed that it is possible to obtain a better than $0.3 \%$ precision from a nominal $0.3 \mathrm{nmol}$ injection.

French researchers state that is possible to measure $\mathrm{Pb}$ isotope ratios directly at low concentration in environmental samples by MC-ICP-MS without the need for chemical purification or without the use of a desolvating high efficiency nebuliser ${ }^{67}$. Using a Faraday cup configuration and a Tl-based mass bias correction protocol, reproducibilities of $0.10 \%(2 \sigma)$ were achieved for ${ }^{206} \mathrm{~Pb} /{ }^{204} \mathrm{~Pb},{ }^{207} \mathrm{~Pb} /{ }^{204} \mathrm{~Pb},{ }^{208} \mathrm{~Pb} /{ }^{204} \mathrm{~Pb}$ ratios and $0.01 \%$ (2 б) for ${ }^{207} \mathrm{~Pb} /{ }^{206} \mathrm{~Pb}$ and ${ }^{208} \mathrm{~Pb} /{ }^{206} \mathrm{~Pb}$ ratios for samples containing $\mathrm{Pb}$ concentrations at $10 \mathrm{ng} \mathrm{ml}^{-1}$ and above, provided that the total sample matrix is maintained at less than $400 \mathrm{mg}^{-1}$. For samples with very low $\mathrm{Pb}$ concentrations, e.g. $100 \mathrm{pg} \mathrm{ml}^{-1}$, a new sample bracketing method was employed; this involves multi-ion counting protocols allowing concurrent measurement of the four lead isotopes in addition to ${ }^{202} \mathrm{Hg}$. Reproducibility of the method was determined to be $0.25 \%$ (2 $\sigma$ ) for ${ }^{206} \mathrm{~Pb} /{ }^{204} \mathrm{~Pb},{ }^{207} \mathrm{~Pb} /{ }^{204} \mathrm{~Pb}$ and ${ }^{208} \mathrm{~Pb} /{ }^{204} \mathrm{~Pb}$ ratios and $0.15 \%$ (2 $\left.\sigma\right)$ for ${ }^{207} \mathrm{~Pb} /{ }^{206} \mathrm{~Pb}$ and ${ }^{208} \mathrm{~Pb} /{ }^{206} \mathrm{~Pb}$ without the need for special sample cleanup procedures. The performance of this method was successfully checked via the analysis of a reference rainwater sample, which had previously been analysed by a TIMS based procedure involving a $\mathrm{Pb}$ purification step. The authors claim that this level of precision is adequate for environmental studies. Noble and coworkers ${ }^{68}$ investigated whether it was possible to undertake $\mathrm{Pb}$ isotope ratio measurements on $\mathrm{PM}_{10}$ particles collected on quartz fibre filters. Using a 266-nm UV laser and a dynamic, low-fluence ablation procedure in conjunction with MC-ICP-MS, they attempted to remove the dust deposited on surface of the filter material rather than ablating the filter matrix. Laser power and raster speeds were optimised to prevent detector saturation and to provide good counting statistics. Mass bias corrections were performed by mixing the ablated stream with a dried $\mathrm{Tl}$ solution generated by a desolvating nebuliser. Results indicated that this laser 'sweeping' procedure was successful, as the $\mathrm{Pb}$ in blank filter to $\mathrm{Pb}$ in sample filter ratios was found to be $\sim 0.1 \%$. It was demonstrated that leaching filter samples with $16 \mathrm{M} \mathrm{HNO}_{3}$ significantly increased the $\mathrm{Pb}$ contribution from a blank filter. Average isotope ratio uncertainties for replicate filter analysis obtained during a single laboratory session were of the order of $\pm 0.3 \%(2 \sigma)$. This was interpreted to be a reasonable estimate of the overall reproducibility accounting for contribution not only from instrumental imprecision but also from within-filter heterogeneity. Isotope ratios measured by LA and solution based procedures on the same filter samples agreed to better than $\pm 0.3 \%$. The authors concluded that whilst analysis by LA is not as precise as a solution-based approach, nevertheless 
it is fit for purpose for many aerosol studies. It has the advantage of not requiring a clean laboratory facility for solution preparation procedures and could be employed where rapid reconnaissance level data are required.

French researchers have optimised a method to determine $\mathrm{Hg}$ isotope ratios by coupling an off-line gold trap to MC-ICP-MS using a syringe injection interface ${ }^{69}$. Historically, measurement precision with on-line gold trap systems has been problematical due to the transient nature of the signal. With their approach, air samples are collected on a gold trap as usual and taken back to the laboratory for analysis. Instead of coupling on-line, $\mathrm{Hg}$ is liberated from the trap into a large volume gas-tight syringe. This syringe is then coupled on-line with the MC-ICPMS system and the gas sample injected at a steady rate thus resulting in a steady state $\mathrm{Hg}$ signal. The external precision on an in-house $\mathrm{Hg}^{0}$ standard was $0.24 \%$ for $\delta^{202} \mathrm{Hg}(2 \sigma)$.

Japanese researchers determined ${ }^{235} U^{238} U$ ratios in airborne particulate matter found on the bark of camphor trees from Hiroshima and Kyoto ${ }^{70}$. Initial matrix element composition and morphologic examinations were carried out by EDAX and SEM procedures. After a dry ash procedure, Dowex ${ }^{\circledR} 1-\mathrm{X} 8$ anion exchange resin was used to separate $\mathrm{U}$ from matrix elements and the purified solutions were subsequently analysed by MC-ICP-MS. The tree bark collected from Hiroshima had significantly higher uranium content compared to that from Kyoto and the ${ }^{235} \mathrm{U} /{ }^{238} \mathrm{U}$ ratios were slightly enriched, probably due to resuspension of particles during the reconstruction of the city.

Plutonium isotope ratios have been investigated using ICP-MS techniques on sediment

and soil samples from the Far East by a number of research groups ${ }^{71-73}$. Not only are the results consistent with those obtained elsewhere in the Northern Hemisphere arising from nuclear bomb tests during the Cold War in the 1960s but also indicate close-in fall out from later Chinese nuclear testing in the 1970's and perhaps more recent releases that could be ascribed to ongoing weapons grade activities.

\subsubsection{X-ray based measurement techniques}

It is apparent that, since metals in atmospheric particles are often now at the $\mathrm{ng}^{-3}$ level; the sensitivity of conventional WD-XRF and ED-XRF systems for filter analysis is an emerging issue, hence the increased use of ICP-MS. However, polarised ED-XRF systems, now commercially available and being used in a few laboratories to analysis air filter samples, offer enhanced sensitivity although published performance data remain scarce. 
The use of biomonitor samples as a proxy to assess the magnitude of metal particulate contamination in the atmosphere continues to attract attention. Russian researchers investigated elemental distributions in tree rings using a high resolution scanning SR-XRF system ${ }^{74}$. A similar approach was used to record the Holecene history in peat core samples ${ }^{75}$. Brazilian researchers analysed tree wood samples using a SR-XRF technique ${ }^{76}$. In a more unusual study, Chinese researchers determined elemental patterns in barbs of primary and secondary flight feathers of a snow petrel collected in Antarctica ${ }^{77}$.

Other $x$-ray based techniques continue to be used in the air monitoring field. Chinese ${ }^{78}$ and Portuguese ${ }^{79}$ groups used PIXE to determine elemental composition of particles in the $\mathrm{PM}_{2.5 / 10}$ range collected on filter samples. TXRF techniques can offer sensitivities on a par with ICP-MS analysis but, to date, have been applied mostly to liquids such as those from sample digestions. Lammel et al..$^{80}$ used a low pressure Berner impactor with four particle sizing ranges of $0.1-0.25 \mu \mathrm{m}, 0.25-1.0 \mu \mathrm{m}, 1.0-4.0 \mu \mathrm{m}$ and $4-16 \mu \mathrm{m}$ to study anthropogenic pollution sources. Modification of the impactor plates with a Perspex support allowed for the direct determination of elements by TXRF without any sample pretreatment and consequently very low detection limits were attainable, e.g. $3-50 \mathrm{pg} \mathrm{m}^{-3}$ for elements such as $\mathrm{As}, \mathrm{Ni}$ and $\mathrm{Pb}$. In this approach, particle size effects must not be underestimated but, nevertheless, this reviewer feels that there is promise in this technique for the future elemental analysis of sub-micron particles.

Characterisation of individual airborne particles and in particular speciation analysis continues to be addressed using x-ray techniques. Finger printing $\mu$-PIXE techniques continues be of interest especially to Chinese ${ }^{81}$ and Japanese analysts ${ }^{82}$ in a region where particulate air pollution is a concern. Researchers at the Sandia National Laboratory in the US have developed an automated expert spectral image program for converting very large amounts of data into the smaller, more manageable number of compositional components needed for locating individual particles of interest on filter samples by scanning $\mu$-PIXE techniques ${ }^{83}$. Speciation analysis using the XANES technique has been carried out by Chinese researchers ${ }^{84}$ who concluded that $\mathrm{Cr}$ in particles collected from the atmosphere above Shanghai was predominately in a trivalent form. Both $\mathrm{Cu}$ and $\mathrm{Mn}$ were predominately found in a +2 oxidation state and $\mathrm{Zn}$ mainly exists as $\mathrm{ZnSO}_{4}$. Spectra obtained on these real samples were found to be similar to those obtained from NIST SRM 1648 Urban particulate matter. Canadian researchers obtained speciation information on $\mathrm{As}, \mathrm{Cr}$ and $\mathrm{Ni}$ in bituminous coal and subsequent waste products of its combustion in a power station ${ }^{85}$. Arsenic in the feed coal was in the form of 
arsenical pyrite and the majority of the As in the waste stream was found in the fly ash fraction in $\mathrm{a}+5$ oxidation state. Chromium in the milled coal was associated with illite in $\mathrm{a}+3$ oxidation state and subsequently found in the bottom ash again in a +3 oxidation state. Nickel was found in $\mathrm{a}+2$ oxidation state in both the input coal and the resultant ash fractions. No evidence was found for the formation of carcinogenic nickel sulphide species. Inputs for $\mathrm{As}, \mathrm{Cu}$ and Ni were 10.45, 123.3 and $36.3 \mathrm{~kg} \mathrm{day}^{-1}$ respectively, of which $0.08,0.71$ and $0.44 \mathrm{~kg}$ day $^{-1}$ were emitted in the stack gas. Mercury emissions were calculated to be $1.8 \mathrm{~g}$ hour $^{-1}$, mostly in the form of reactive $\mathrm{Hg}^{2+}$ species followed by $\mathrm{Hg}^{0}$ and $\mathrm{Hg}^{\mathrm{p}}$.

Solid state speciation techniques have been used to explore the heterogeneous chemistry of atmospheric particles. American researchers used a battery of advanced instrumental techniques, including STXM-NEXAFS, to determine the speciation of sulphur in marine cloud droplets and particles ${ }^{86}$. Results indicated substantial heterogeneous replacement of chloride in sea salt $(\mathrm{NaCl})$ particles by methanesulphonate and non-sea-salt sulphate. Tropospheric mineral aerosols affect global atmospheric composition and thermal equilibrium. Studies have identified carbonate minerals as an important component because of their robust reactivity with gaseous nitric acid. Bramante et al. ${ }^{87}$ used EXAFS to examine the interaction of strontium carbonate particles with gaseous $\mathrm{HNO}_{3}$ and $\mathrm{NO}_{2}$. Readers wishing to learn more about developments in Xray techniques should consult our companion Update on X-ray fluorescence spectrometry ${ }^{88}$.

\subsubsection{Other mass spectrometry based techniques}

Accelerator mass spectrometry as a tool to investigate climatic change events continues to grow, in part due to its increasing availability. Swiss researchers describe a technique to extract carbonaceous particles from ice cores with subsequent analysis of their OC/EC ratios and their respective ${ }^{14} \mathrm{C}^{12} \mathrm{C}$ ratios by $\mathrm{AMS}^{89}$. It is hoped that by looking at the past, using archived samples such as ice core samples, it will become possible to estimate the influence of carbonaceous particle releases into the atmosphere on future climate. Japanese researchers describe a volatilisation procedure to separate iodine from soil samples ${ }^{90}$. The liberated iodine is trapped in a solution, purified by solvent extraction and finally precipitated as AgI to form a target for AMS analysis. A European research group similarly liberated iodine by combustion of soil samples in an oxygen atmosphere ${ }^{91}$. A number of papers report AMS determination of ${ }^{10} \mathrm{Be} /{ }^{7} \mathrm{Be}$ ratios in air filter samples ${ }^{92}$, ice core samples ${ }^{93}$ and precipitation samples ${ }^{94}$. 
Henning and co-workers ${ }^{95}$ describe a versatile inlet system for on-line determination of hydrogen and carbon compound-specific stable isotope ratio measurements by IRMS. The custom-built gas sampling and injection system provides flexibility, ease of operation and economic use of small gas samples with wide ranges of analyte concentration; this in turn is coupled to two alternative reactors: an oxidative chamber for production of $\mathrm{CO}_{2}$ or a reductive chamber for the production of $\mathrm{H}_{2}$. Nogues et al..$^{96}$ have developed a method for the capture of internal gas samples for the measurement of intercellular $\mathrm{CO}_{2}$ in plant cells by GC-C-IRMS. Chinese researchers determined the carbon isotope composition of atmospheric acetone by a GCC-IRMS after trapping and derivationation as a 2,4-dinitrophenylhydrazine adduct ${ }^{97}$.

\subsubsection{Other elemental measurement techniques}

Organic atmospheric particles make up a significant fraction of ambient particulate mass. Organic carbon measured with a combustion analyser is often used as a marker of organic particles and a correction factor applied to determine total concentrations of organic matter. Chen and $\mathrm{Yu}^{98}$ have devised a top-down approach to determine such correction factors. The organic mass is taken to be the mass difference of a filter sample before and after heating at $550{ }^{\circ} \mathrm{C}$ in air for 4 hours minus mass losses due to elemental carbon, volatile inorganic compounds, e.g. ammonium nitrate, and loss of bound water. By using separate aliquots from filter samples, the elemental carbon was determined using a combustion technique and the volatile inorganic species determined by IC after leaching in water before and after the heat treatment step. They analysed 37 filters samples and calculated this factor to be $2.1 \pm 0.3$ for aerosol samples collected in Hong Kong. This factor is however expected to have considerable spatial and temporal variability and they suggest that site-specific factors should be measured to obtain more accurate aerosol mass closure data in aerosol studies. Viana et al. ${ }^{99}$ performed comparative analysis of $\mathrm{OC}$ and EC in carbonaceous aerosols collected from three European cities. One of their aims was to investigate sampling artifacts due to differences in climatic conditions and carbon sources in a Southern European urban environment (Barcelona) and a Western European urban environment (Amsterdam and Ghent). By using common air samplers with the resultant combustion analysis carried out at a single laboratory it was possible to compare results. Quartz fibre filters are commonly used to sample carbonaceous aerosols prior to combustion analysis and Finnish researchers ${ }^{100}$ validated the collection characteristics of a small deposit low pressure impactor sampler employing such filters to ultimately undertake size distribution $\mathrm{OC} / \mathrm{EC}$ measurements. 
Rebits and co-workers ${ }^{101}$ used a TOC analysis procedure to quantify the sample collected by an Andersen Cascade Impactor used in the pharmaceutical industry for determination of the size distribution of particles emitted from a dry powder inhaler. The ability to correctly determine particle size distribution with such impactor systems historically depended significantly upon the accuracy and precision of gravimetric measurements, i.e. mass measurements of small quantities of size segregated particles collected on impaction plates. Here an alternative sensitive chemical measurement procedure is presented which can also discriminate between accumulated water mass and organic particles of interest.

\subsection{Field and on-line based measurements}

\subsubsection{AAS, AFS and AES based measurement techniques}

Real-time in situ measurements of mercury in the atmosphere are being facilitated by the commercial availability of the Tekran instrument, which was described in detail in last year's Update $^{1}$. In summary, the instrument is based around a gold trap preconcentrator system equipped with an AFS detector. Fritsche et al. ${ }^{102}$ used this instrument to determine $\mathrm{Hg}^{0}$ concentrations over sub-alpine grasslands in Switzerland in an attempt to determine deposition fluxes. Likewise, Wang et al. ${ }^{103}$ determined airborne concentrations of $\mathrm{Hg}^{0}$ in the vicinity of the Wuchuan mine in Guizhou province, China, located in the Circum-Pacific Global Mercuriferous Belt, in an attempt to determine $\mathrm{Hg}$ fluxes in a geologically enriched zone. In a more pristine environment, Brooks et al. ${ }^{104,105}$ ], for the first time, speciated $\mathrm{Hg}^{0}, \mathrm{Hg}^{2+}$ and $\mathrm{Hg}^{\mathrm{P}}$ forms in the atmosphere above the McMurdo Sound and Ross Island sea ice region of Antarctica and studied the conversion mechanism at the snow surface of deposited $\mathrm{Hg}^{2+}$ to $\mathrm{Hg}^{0}$ and its subsequent rerelease. In order to have confidence in measured values, in particular those made in response to regulatory requirements, validated analytical methodologies that have traceable measurement uncertainty statements are required. Brown and coworkers ${ }^{106}$ at the UK National Physical Laboratory present a practical uncertainty budget for the measurement of vapour phase $\mathrm{Hg}$ in ambient air where sampling is onto a gold-coated silica adsorption tube and laboratory measurement is by AFS after thermal release. They suggest that their approach is generic in nature and can be adapted by others undertaking similar mercury vapour measurements.

Laser induced breakdown spectroscopy offers a potential means of measuring aerosols in real-time. That said, the technique is in its infancy and fundamental research into LIBS is being undertaken by several research groups. Simpson et al. ${ }^{107}$ have provided evidence for a spatial 
distribution of signal in LIBS measurements of single aerosol particles. Mukherjee and Cheng ${ }^{108}$ present results indicating matrix effects induced by mass loading of the plasma during the application of LIBS for estimation of carbon content in aerosols. These could hamper our ability to make quantitative measurements. Diwakar et al. ${ }^{109}$ examined localised matrix effects by studying changes in $\mathrm{Na}$ or $\mathrm{Mg}$ analyte emission response from particle-derived sources after the addition of concomitant mass to the aerosol particles. Initially, it is likely that LIBS will be applied quantitatively where well-characterised aerosols are generated under controlled conditions. Mukherjee and Cheng ${ }^{110}$ suggest that the technique could be used for quality control purposes in the manufacture of aerosolised drug delivery systems. These are increasingly becoming popular because of advancements in production of nano-sized drug particles that potentially can be delivered to target organs via an inhalation route. Their initial studies, involving three different carbon-based aerosolisable drugs, focused on quantitative measurement of $\mathrm{C} / \mathrm{Ca}, \mathrm{C} / \mathrm{Fe}$ and $\mathrm{C} / \mathrm{Mg}$ ratios, which agreed within experimental error with the respective stoichiometric values.

\subsubsection{X-ray based measurement techniques}

Portable XRF systems offer the potential to undertake analysis directly in the field. Korean researchers used a portable system to measure $\mathrm{Pb}$ levels in workplace air ${ }^{111}$. Dust samples were collected using standard closed-faced 37-mm diameter filter sampling cassettes widely used in the US for workplace air monitoring surveys. Filter samples were analysed to the NIOSH 7702 standard protocol and then reanalysed in the laboratory by ICP-AES to conditions set out in NIOSH 7300. A paired t-test revealed no statistically significant differences between the two methods over the range of airborne $\mathrm{Pb}$ sampled $\left(0.018-0.201 \mathrm{mg} \mathrm{m}^{-3}\right)$. Linear regression of the data produced a slope of 1.03 and a correlation co-efficient of 0.975 . These data are reassuringly good as there is an ongoing debate in this particular measurement field about the general capabilities of PXRF to provide data of a quality on a par with that of laboratory measurements using ICP techniques. This debate - and work is being carried out in this reviewer's laboratory and elsewhere - centres around concerns about dust losses to sampler walls, particle and depth effects of dust on filter samples and potential for inhomogeneity of surface dust deposit when viewed with the small x-ray beam profiles of PXRF systems. In an interesting application, French researchers used a PXRF system to measure sulphur on the 
weathered surface of stone monuments that have been attacked by $\mathrm{SO}_{2}$. They see the technique as a useful monitoring tool in cultural heritage conservation studies ${ }^{112}$.

\subsubsection{Mass spectrometry based measurement techniques}

Drewnick and co-workers ${ }^{113}$ characterised aerosol particles released from grass cutting by deploying both quantitative aerosol particle mass spectrometry and single particle qualitative mass spectrometry. Additionally, a range of other on-line aerosol concentration and size distribution instrumentation was deployed. Grass cutting was found to generate two distinct group of particles: an intense ultrafine mode of particles relating to near pure hydrocarbon particles from lawn mower exhaust, and a coarser size particle with potassium and nitrogenorganic compounds associated with plant debris. It is estimated that some $160,000 \mathrm{~km}^{2}$ in mainland USA is cultivated with lawn representing not only $2 \%$ of the surface area of the country but approximately half of the urbanised area! In a similar fashion, German researchers used a battery of techniques, including a real-time aerosol mass spectrometer, within a mobile laboratory to characterise traffic-related emissions on motorways, rural roads and in city traffic $^{114}$. Results indicated that the main influence of traffic on the aerosol properties resulted in soot particles coated with organic matter, having a modal diameter of approximately $100 \mathrm{~nm}$ and where highest numbers were found in inner city traffic. Smaller $30 \mathrm{~nm}$ particles, consisting of mainly of organic compounds but also potentially including a sulphuric acid core, were observed during 'truck-chasing' events i.e. following articulated lorries at a distance of between 50 - 100 $\mathrm{m}$ on motorways. Diesel fuel specific emission ratios were derived for a subset of eighteen such 'truck-chasing' events, yielding $8.3 \pm 5.8 \times 10^{15} \mathrm{~kg}^{-1}$ fuel for particle numbers, $224 \pm 136 \mathrm{mg} \mathrm{kg}^{-}$

${ }^{1}$ for black carbon and $125 \pm 136 \mathrm{mg} \mathrm{kg}^{-1}$ for organic matter. Single particle mass spectrometry techniques continue to be used by the Prather research group in the US for the on-line source apportionment of ambient aerosols emitted from motorway traffic ${ }^{115}$. The particle contribution alongside a motorway, in the ultrafine and accumulation size range of $50-300 \mathrm{~nm}$, was apportioned as 32\% from gasoline powered vehicles, 51\% from diesel powered heavy duty vehicles and $17 \%$ from other sources. Dreyfus and Johnston ${ }^{116}$ present highly time resolved measurements of individual organic aerosol species. A mini-VACES system was used to concentrate the particle aerosol steam and to present sample particles for interrogation using a photoionisation aerosol mass spectrometer. The 'soft ionisation' mode of this system allowed for the identification of various chemical compounds using a signature ion, often the molecular ion. 
The fast response of this combined system when combined with meteorological data provided rapid and detailed information concerning changes in airborne concentrations of various organic species which in some cases could be fingerprinted to potential source locations. It is hoped that quantification may be achievable by referencing to other measurement data obtainable from other instrumentation such as GC-MS, carbon species analysers and particle sizing instrumentation.

\subsubsection{Other elemental measurement techniques}

Traditionally, water-soluble inorganic ions such as nitrate and sulfate, which constitute a large proportion of airborne particulate matter, have been determined by filter-based sampling methods followed by analysis of extracted ions by colorimetric and IC techniques. Chinese workers report results of an intercomparison between a new semi-continuous instrument and conventional filter-based methods ${ }^{117}$. A rural location outside Beijing dominated by farming activities and an urban location in Shanghai dominated by industrial activities and coal-fired power stations were selected as sampling sites. In the semi-continuous system, inlet air is sampled at a nominal $3.51 \mathrm{~min}^{-1}$ through a $\mathrm{PM}_{2.5}$ cyclone and then passed through a liquid diffusion denuder in order to remove interfering gases such as $\mathrm{HNO}_{3}$ and $\mathrm{SO}_{2}$. Particles are then passed into a steam generator chamber where supersaturation causes particles to grow rapidly into droplets. These enlarged droplets pass through an inertial particle separator and are stored in a sample collector. Sample aliquots are then taken and analysed on-line for both cationic and anionic species using a dual column IC system. Detection limits for this system for various ionic components were around $0.1 \mu \mathrm{g} \mathrm{m}^{-3}$ based on an hourly sampling frequency. The two methods agreed very well for sulfate at both sampling sites where pollution levels were relatively low, i.e. $<20 \mu \mathrm{g} \mathrm{m}^{-3}$ and $\mathrm{SO}_{2}<30 \mathrm{ppbv}$. Where $\mathrm{SO}_{2}$ levels were higher, false positive sulfate results were obtained with the semi-continuous system, which was attributed to the capacity of the liquid denuder being overloaded. At high sulfate concentrations, the instrumental data were biased low against the filter method and this was attributed to a deficiency in the system to fully leach sulfate ions from the particles. For nitrate determinations, both approaches were in agreement for samples taken at the Shanghai site, but attempts to correlate data at the Beijing site were hampered by evaporative losses from filters and negative bias in the semi-continuous system at high airborne particle loadings. The authors conclude that whilst the semi-continuous system can provide automated time-resolved data at less polluted sampling sites, some modifications to the 
system may be required for more polluted urban sites. These include increasing denuder capacity either by using larger denuders, denuders in series and/or replacing the water in the scrubbing solution with $\mathrm{H}_{2} \mathrm{O}_{2}$ or an alkaline solution to increase efficiency in removing acidic gas species. They also suggest that, in the case of high atmospheric particulate loading, increasing the particle leaching step by either reducing the inlet air flow rate, which would change the size selection characteristics of the cyclonic inlets unless modifications are made, or increasing the water supply to the steam generator to enhance capacity for dissolving water soluble ions would be necessary. An international research consortium compared the performance of a semicontinuous IC system against filter sampling approaches at a pasture site in Brazil ${ }^{118}$. Correlation between data from both samplers was poor and discrepancies attributed to a complex combination of different effects were noted. The authors conclude that measurement of inorganic aerosol compounds is much more challenging under tropical conditions of high temperature and high humidity and influenced by biomass burning than in many of the studies that have been conducted in temperate latitudes of the Northern Hemisphere.

\section{Water analysis}

This section highlights new developments and improved analytical methods that use atomic spectroscopy for the determination of trace metal(loid)s and their associated elemental species in environmental water samples reported since the last Update ${ }^{1}$. Significant areas of activity currently focus on elemental speciation, vapour generation and metrology. Tables summarizing the pre-concentration and extraction procedures that will be of particular interest to analysts with access to AAS and its associated variants have been included.

\subsection{Sample preparation.}

\subsubsection{Sample collection, preservation and filtration procedures}

In situ sampling devices have been reported for total and functional metal species capture. A passive sampling device ${ }^{119}$ for use with GC-ICP-MS or GC-FPD has been developed for monitoring inorganic $\mathrm{Hg}$ and organotin compounds (MBT, DBT, TBT) in harbour water. The apparatus is based on diffusion of the target compound through a membrane and subsequent accumulation by a specific receiving phase. An Empore ${ }^{\mathrm{TM}}$ chelating disk was used as the receiving phase for inorganic $\mathrm{Hg}$ with polyethersulfone as the diffusion membrane, whereas for the organotin compounds an Empore ${ }^{\mathrm{TM}} \mathrm{C}_{18}$ disk and cellulose acetate were utilized. The effect 
of environmental factors such as salinity, $\mathrm{pH}$ and temperature on the uptake of the target analytes was studied and a linear uptake was observed for at least 14 days. The samplers were tested in the field and their effectiveness was evaluated by comparison with the results obtained from spot sampling. The data from both the laboratory and field based tests indicated that the samplers worked well for the measurement of the dissolved fraction of these analytes. Detection limits between 0.7 and $5.9 \mathrm{ng} \mathrm{L}{ }^{-1}$ were reported. In a similar vein, Tonello et al. ${ }^{120}$ used diffusive gradient thin film (DGT) technology in combination with ultra-filtration and ICP-MS to measure free and humic-bound $\mathrm{Al}$ and $\mathrm{Cu}$ in organic-rich river and synthetic water solutions.

\subsubsection{Pre-concentration, extraction and separation procedures}

Two main approaches for preconcentration of trace elements from water have dominated the literature recently: cloud point extraction (CPE) and the use of columns packed with chemical adsorbents. These methods will be of interest to workers requiring an LOD commensurate with the determination of trace metals in drinking water by techniques such as FAAS, which require analyte preconcentration to deliver this degree of sensitivity. The SPE applications are given in Table 1 and the cloud point extraction methods in Table 2.

\subsection{Speciation}

The determination of elemental speciation in environmental water samples has continued to figure strongly in the literature. New approaches to the measurement of compounds containing hetero-atoms, particularly phosphorus and halides, have been reported. The instrumentation has utilized both GC and HPLC coupled to different elemental detection systems. Chromium speciation has received considerable interest and the methods have involved similar hyphenated chromatography - atomic spectroscopy systems, as well as simple column based approaches (see Table 1).

The measurement of toxicologically important P-containing environmental contaminants using elemental detection by ICP-MS has once again received attention. The recently established Centre for Elemental Speciation, located in Cinncinnati, has focused on the determination of organophosphorous herbicides, nerve agent degradation products, fireretardants and plasticizers by measurement of P. A system based on GC-ICP-MS was used for the analysis of 7 organophosphorous nerve agent degradation products ${ }^{121}$ and the screening of these products in the presence of organophosphorous pesticides ${ }^{122}$. Due to the non-volatile 
nature of the alkyl phosphonic acid degradation products, derivatization to the corresponding volatile tert-butyl dimethylsilyl species was required. The exact mass confirmation of the formation of the derivatives was obtained using GC-TOF-MS. The determination of organophosphorus containing fire-retardants and plasticizers ${ }^{123}$ at trace concentrations in waste water has also used this GC-ICP-MS instrumental set-up, except in this case derivatization was not required and MAE and SPME were used for sample extraction and preconcentration. The detection limits for organophosphorous fire retardants were $29 \mathrm{ng} \mathrm{L}^{-1}$ for tri-n-butyl phosphate, $45 \mathrm{ng} \mathrm{L}^{-1}$ for tris(2-butoxyethyl) phosphate and $50 \mathrm{ng} \mathrm{L}^{-1}$ for tris(2-ethylhexyl)phosphate. GCTOF-MS was again used to confirm species identity. Another research group studying organophosphorus compounds has used HPLC coupled to a reaction cell ICP-MS instrument ${ }^{124}$, for the determination of the P-containing herbicide glyphosate and its main environmental metabolite, aminomethyl phosphonic acid. In this case $\mathrm{P}$ was measured as $\mathrm{PO}^{+}$, using oxygen as the reaction gas within the cell. They used a two stage sample preconcentration system involving Chelex 100 and AG1-X8 resins to monitor glyphosate at the EU drinking and surface water limit of $0.1 \mu \mathrm{g} \mathrm{L}^{-1}$. The developed method was applied to the analysis of Austrian river water and waste water samples, where both species were detected.

Speciation methods for halide-containing compounds involving hyphenated chromatographic - element specific detection have been developed. An important illustration of the quantitative power of ICP-MS detection for speciation analysis has been reported by the group of Alonso ${ }^{125}$. By using GC-ICP-MS and an internal standard of $\mathrm{CBrCl}_{3}$ the possibility for compound independent calibration for the simultaneous determination of the trihalomethanes $\mathrm{CHCl}_{3}, \mathrm{CHBrCl}_{2}, \mathrm{CHBr}_{2} \mathrm{Cl}$ and $\mathrm{CHBr}_{3}$ in drinking water was realised. For the determination of all four compounds in one single injection by detection of ${ }^{35} \mathrm{Cl}$ and ${ }^{79} \mathrm{Br}$, only the addition of a known amount of the internal standard to the sample followed by extraction into n-pentane was required. The methodology met the requirements for the routine determination of THMs in drinking water. The determination of iodine speciation by HPLC coupled to ICP-MS detection $^{126}$ has focused on the preservation and measurement of iodide, iodate and organoiodine compounds in groundwater samples using SEC-ICP-MS. Further studies ${ }^{127}$ indicated a sensitivity difference between iodate and iodide species, which was subsequently resolved by using a preservation medium of $0.01 \% \mathrm{KOH}$, for both standards and samples. Anion-exchange chromatography coupled to ICP-MS detection ${ }^{128}$ has been used for the determination of iodate 
and iodide in seawater samples. The developed method allowed the direct analysis of the sample for these analytes without pretreatment, except for dilution with deionized water.

The speciation of chromium in water samples often receives attention because of the toxicity and hence regulations that are associated with $\mathrm{Cr}^{\mathrm{VI}}$. This trend has continued. Methods based on column chromatography feature significantly (see Table 1) as do methods based on the coupling of chromatography to element specific detection. Wolf et al. ${ }^{129}$ developed a method for the simultaneous determination of $\mathrm{Cr}^{\mathrm{III}}$ and $\mathrm{Cr}^{\mathrm{VI}}$ in natural waters. Separation of the species was possible in less than two minutes using a reversed-phase HPLC system coupled to a reaction cell ICP-MS instrument. The chromatography utilized an ion-pair reagent (TBAOH) and complexation of $\mathrm{Cr}^{\mathrm{III}}$ with EDTA prior to sample injection. One of the significant features of the method was a reaction cell to reduce the $\mathrm{ArC}^{+}$polyatomic ion background at $\mathrm{m} / \mathrm{z} 52$. With ammonia in the reaction cell it was possible to reduce the background signal by over 4-orders of magnitude. Method detection limits of 90 and $60 \mathrm{ng} \mathrm{L}^{-1}$ were subsequently achieved for $\mathrm{Cr}^{\mathrm{III}}$ and $\mathrm{Cr}^{\mathrm{VI}}$ respectively, using an injection volume of $50 \mu \mathrm{L}$. Both MIP-OES and ICP-OES have been compared as HPLC detectors for $\mathrm{Cr}$ speciation ${ }^{130}$. Hyphenated systems using MIPs usually involve GC separations, because of the poor tolerance of the MIP to the liquid flow rates used with HPLC chromatography. In this work, coupling between the HPLC and the detector was achieved via a hydraulic high pressure nebulizer with radiative heating and watercooling interface, which produced a desolvation efficiency for aqueous solutions of $80 \%$. Suppression effects caused by the organic modifier and other reagents in the eluent reduced the MIP signal intensity by 50 to $75 \%$ for $\mathrm{Cr}^{\mathrm{VI}}$ and by 25 to $50 \%$ for $\mathrm{Cr}^{\mathrm{III}}$. This necessitated species dependent calibration, thus negating one of the major advantages of speciation analysis. The MIP-OES detector delivered LODs of 13 for $\mathrm{Cr}^{\mathrm{III}}$ and $18 \mathrm{ng}$ for $\mathrm{Cr}^{\mathrm{VI}}$, whereas ICP-OES gave LODs of 0.2 for $\mathrm{Cr}^{\mathrm{III}}$ and $0.4 \mathrm{ng}$ for $\mathrm{Cr}^{\mathrm{VI}}$.

Methods for the speciation of selenium, both organoselenium and the different Se oxidation states have been developed. Campillo et al. ${ }^{131}$ compared two different derivatization agents for the determination of selenite, dimethylselenide and dimethyldiselenide in water samples by GC-AED, after preconcentration by SPME. Using sodium tetraethylborate, a common derivatizing agent for aqueous phase organotin and organomercury analysis, and

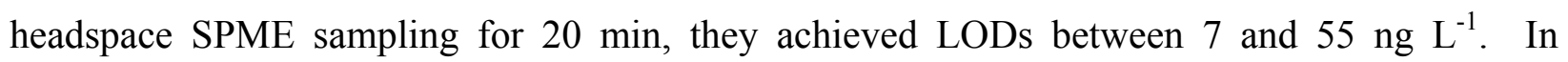
comparison, derivatization with 4,5-dichloro-1,2-phenylenediamine using immersion extraction and a longer extraction time, provided lower LODs of between 3 and $25 \mathrm{ng} \mathrm{L}^{-1}$. Interestingly 
from an environmental perspective, both DMSe and $\mathrm{Se}^{\mathrm{IV}}$ were detectable in environmental water samples. In contrast, anion-exchange separation coupled to an octapole ICP-MS reaction system $^{132}$ has been reported for the determination of Se oxidation states. The reaction cell utilized $\mathrm{H}_{2}$ to overcome the argon polyatomic interferences and allow for the detection of the most abundant ${ }^{80} \mathrm{Se}$ isotope. With a pH 6.5 buffer system, both oxidation states of Se could be determined in natural water samples with LODs of 0.4 for $\mathrm{Se}^{\mathrm{IV}}$ and $0.6 \mu \mathrm{g} \mathrm{L}^{-1}$ for $\mathrm{Se}^{\mathrm{VI}}$. A study into the advantage of using VG as an interface for the determination of Se-containing species ${ }^{133}$ by HPLC-ICP-MS has been reported. Once again a collision/reaction cell instrument was used, but in this case with a mixture of $\mathrm{He}$ and $\mathrm{H}_{2}$ as the collision gas. The main advantage of a VG interface was the elimination of the $\mathrm{BrH}^{+}$interference, which allowed for the determination of the ${ }^{80} \mathrm{Se}$ isotope and gave species specific LODs of between 7 and $15 \mathrm{ng} \mathrm{L}^{-1}$.

Studies on thioarsenic compounds in natural waters have continued. The research group at Trent University, Ontario, have further developed their method based on anion-exchange chromatography coupled to ICP-MS and applied it to the detection of thioarsenates in geothermal waters from Yellowstone National Park ${ }^{134}$ and methylated arsenic-sulfur compounds in groundwater samples ${ }^{135}$. Mono-, di-, tri- and tetra- thioarsenates, along with methylated oxyand thio- anions were identified in the geothermal waters using retention time matching with synthetic standards, measurement of the S : As ratios and electrospray mass spectrometry. Groundwater samples from an aquifer contaminated with As-containing pesticides were shown to contain methylated oxy- and thio- anions, which were identified using retention times and electrospray analysis of collected HPLC fractions. Flash-freezing was used to preserve the species information, as acidification of the samples with $\mathrm{HCl}$ caused the loss of the total dissolved arsenic.

Simultaneous speciation of multiple elements using systems based on HPLC are always of interest because of the difficulties associated with the separation in the liquid phase of organometallic species containing different elements. Morita et al. ${ }^{136}$ have developed a method for species containing $\mathrm{As}$ and $\mathrm{Sb}$, based on a $\mathrm{C}_{30}$ reversed phase column and detection by ICPMS, which they applied to hot-spring waters. Eight different arsenic-containing species, As ${ }^{\mathrm{III}}$, $\mathrm{As}^{\mathrm{V}}$, MMA, DMA, AB, AC, TMAO, TMA, and two antimony species $\mathrm{Sb}^{\mathrm{III}}$ and $\mathrm{Sb}^{\mathrm{V}}$, were separated with a mobile phase containing ammonium tartrate. 


\subsection{Instrumental analysis}

\subsubsection{Atomic emission spectrometry}

In two related papers ${ }^{137,138}$ Hieftje's group have described a compact glow discharge for the elemental analysis of aqueous samples. Glow discharge sources have traditionally been illsuited for the analysis of liquids, being mainly applied to the analysis of solids. However, in recent years, such sources operating at atmospheric pressure have shown promise. The miniaturised glow-discharge uses the solution to be analysed as the cathode and was operated in a transient mode with emission spectrometry for detection. A $25 \mu \mathrm{L}$ sampling volume, at 1000 samples per hour, yielded LODs ranging from 0.2 for $\mathrm{Li}$ to $270 \mu \mathrm{g} \mathrm{L}{ }^{-1}$ for $\mathrm{Hg}$.

\subsubsection{Vapour generation methods}

New instrumental configurations to enhance and improve vapour generation for the analysis of water samples have been reported. Ultra-sound (US) has been applied to the determination of $\mathrm{Hg}^{139}$ via CV generation and US fields of sufficient density to achieve both localized heating and radical-based reactions involving TMAH, formic and acetic acids. Thermal reduction of $\mathrm{Hg}^{2+}$ is efficient using formic acid and TMAH at $70{ }^{\circ} \mathrm{C}$ and occurred in the absence of the US field. The reduction of MeHg occurred at high US field density, making the speciation of $\mathrm{Hg}$ possible by altering the power density during the measurement process. A new approach to atom trapping ${ }^{140}$ utillizing an air-acetylene heated integrated-atom-trap was applied to the determination of inorganic $\mathrm{Sb}$ in water samples. The system could also be used to determine $\mathrm{Sb}$ oxidation states by analysis of samples treated with and without L-cysteine and calculation of $\mathrm{Sb}^{\mathrm{V}}$ from the difference between total $\mathrm{Sb}$ and $\mathrm{Sb}^{\mathrm{III}}$. The developed method delivered an LOD in the sub $\mathrm{n} \mathrm{L}^{-1}$ range for a $2 \mathrm{~mL}$ sample volume and was applied to the measurement of Sb in natural water samples, including the NIST SRM 1643e, Trace elements in water. A miniaturised AFS system was developed based on a novel lab-on-valve configuration $^{141}$. The system integrated a micro-scale VG chamber with a PTFE membrane, which operated as a gas-liquid seperator. The CV was generated with NaTHB and excited in the outlet of the membrane by incident light from a Hg HCL and the fluorescence signal monitored with a side-on photomultiplier. Both the incident light and fluorescence were transmitted by fibre opics. The system was applied to the determination of $\mathrm{Hg}$ in sea and river water and generated an LOD of $20 \mathrm{ng} \mathrm{L}^{-1}$. 
A new approach to the determination of sulfate and sulfide in natural waters based on the generation of hydrogen sulfide has been reported. Colon et al. developed two related systems ${ }^{142,}$ ${ }^{143}$ for the measurement of these species. The simplest design ${ }^{142}$ was based on $\mathrm{H}_{2} \mathrm{~S}$ generation by acidification of the sample with $\mathrm{HCl}$ prior to analysis using ICP-AES. The sulfur emission intensity in this case is due to both sulfate and sulfide species. The contribution of sulfide is obtained by calculating the difference between the emission intensity measured directly from the sample and that measured in the acidic medium. The more complex system ${ }^{143}$, based on a conventional VG-ICP-MS instrumental set-up, was used to determine sulfide in water samples at the sub- $\mu$ g $\mathrm{L}^{-1}$ level. Once again $\mathrm{H}_{2} \mathrm{~S}$ was generated from the reduced-sulfur species after reaction with $\mathrm{HCl}$ in a commercial $\mathrm{VG}$ system and $\mathrm{S}$ was measured at $\mathrm{m} / \mathrm{z} 32$. Polyatomic interferences were eliminated by a mixture of $\mathrm{He}$ and $\mathrm{H}_{2}$ gases in the octapole reaction cell of the ICP-MS instrument.

A vapour generation system utilizing UV photochemical degradation has been developed for the speciation of inorganic $\mathrm{Se}^{144}$ and the determination of $\mathrm{Hg}^{145}$ in natural water. Both applications used simple organic compounds in conjunction with a $\mathrm{TiO}_{2}$ catalyst to generate vapour and could be coupled to a variety of detection systems. The speciation system is based on the Se oxidation states reacting with an organic acid under different thermal conditions; at low temperature only $\mathrm{Se}^{\mathrm{IV}}$ could be photochemically converted to a volatile species, whereas both species are volatilized using a boiling water bath and nano- $\mathrm{TiO}_{2}$ as a catalyst, thus allowing

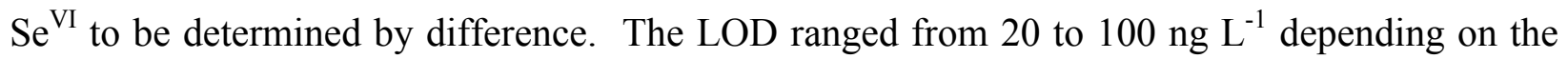
organic acid and detector used. For the trace $\mathrm{Hg}$ method, UV irradiation in the presence of simple organic compounds such as methanol, glycerol, acetic or oxalic acids generated the CV with the reaction efficiency being enhanced in the presence of nano- $\mathrm{TiO}_{2}$. The authors evaluated the system with AFS detection, which provided an LOD of $20 \mathrm{ng} \mathrm{L}^{-1}$ for $\mathrm{Hg}$.

\subsubsection{X-ray fluorescence spectrometry}

The on-line coupling of FI and SPE to energy dispersive XRF has been reported for the determination of $\mathrm{Cd}$ and $\mathrm{Pb}$ in $\operatorname{tap}^{146}$ and waste waters ${ }^{147}$. An FI manifold, incorporating an SPE column packed with Dowex 50 cation-exchange resin, was coupled directly to a lab-made $18 \mu \mathrm{L}$ flow-cell of $10 \mathrm{~mm}$ path length, located in the X-ray spectrometer irradiation chamber ${ }^{147}$. Injection of a $20 \mathrm{~mL}$ aliquot of sample provided LODs of 1.8 for $\mathrm{Cd}$ and $1.0 \mu \mathrm{g}$ for $\mathrm{Pb}$ and the system was used to analyse waste water samples by the standard additions method. In the 
second system ${ }^{146}$ the same absorbent material was packed into a PTFE lab-made flow cell, which was located directly in the irradiation chamber of the EDXRF instrument. Injection of a $100 \mathrm{~mL}$ aliquot of sample provided LODs of 0.3 for $\mathrm{Cd}$ and $0.15 \mu \mathrm{g}$ for $\mathrm{Pb}$ and the system was used to analyse tap water samples by the standard additions method.

The use of activated thin layer solid supports in combination with XRF has been reported $^{148}$ for the determination of $\mathrm{Cd}$. The thin layers were activated with Aliquat 336 and prepared either by direct impregnation of commercial polymeric supports or by physical inclusion in a cellulose triacetate matrix. Both materials were used to collect $\mathrm{Cd}$ from spiked seawater. The absorbed $\mathrm{Cd}$ was quantified by high-energy polarized beam EDXRF, which gave an LOD of $0.7 \mu \mathrm{g} \mathrm{L}^{-1}$ and a linear response from solutions containing between 5 to $8000 \mu \mathrm{g} \mathrm{L}^{-1}$ Cd.

\subsubsection{Inductively coupled plasma mass spectrometry}

Isotope ratio measurements based on ICP-MS have been reported for the investigation of isotope fractionation in natural water systems. The performance of five different sample introduction methods for rapid and precise measurement of Se isotope ratios by multi-collector ICP-MS has been evaluated ${ }^{149}$ : a conventional cross flow nebulizer and spraychamber, two different desolvation units, a multi-mode sample introduction system (MSIS) and a HG set-up. The objective was to establish which provided the highest $\mathrm{Se} \mathrm{S} / \mathrm{N}$ ratio and best isotope ratio precision. The HG approach yielded the maximum sensitivity and precision, it provided $\mathrm{S} / \mathrm{N}$ ratios for all Se isotopes five times higher tha those from MSIS, 20 times the $\mathrm{S} / \mathrm{N}$ ratios of both desolvation units and 100 times the $\mathrm{S} / \mathrm{N}$ ratios produced by the conventional nebuliser. For example, the internal precision achieved for the ${ }^{78} \mathrm{Se} /{ }^{82} \mathrm{Se}$ ratio at a concentration of $100 \mu \mathrm{g} \mathrm{L}{ }^{-1}$ Se with the conventional nebuliser, two desolvation units, MSIS and HG interface was 150, 125, 114, 13 and 7 ppm respectively. The mass bias was also assessed, with the HG system giving the lowest value and the desolvation unit the highest. A new extraction method has been reported ${ }^{150}$ for the determination of $\mathrm{Ce}$ isotope ratios in seawater samples. The ${ }^{138} \mathrm{Ce} /{ }^{142} \mathrm{Ce}$ ratio is used for dating and as a chemical tracer in geochemistry and cosmochemistry. For the most reliable measurements, selective chemical separation is needed to isolate the Ce isotopes from other REE and $\mathrm{Ba}$ isotopes present in the samples. The highly selective sample preparation technique involved the oxidation of $\mathrm{Ce}^{\mathrm{III}}$ to $\mathrm{Ce}^{\mathrm{IV}}$ with $\mathrm{KBrO}_{3}$ in nitric acid, followed by extraction with a chelating resin. The method excluded interfering elements such as $\mathrm{Ba}, \mathrm{La}, \mathrm{Pr}$ and $\mathrm{Nd}$ to 
levels less than $0.1 \mathrm{ng}$ and yielded consistent Ce isotopic data for seawater samples from the Pacific Ocean.

Protocols utilizing collision or reaction cell instrumentation to reduce commonly occurring polyatomic interferences have been reported. Grotti and Frache ${ }^{151}$ developed a method for the direct determination of As in 15-fold diluted seawater samples using ICP-MS instrumentation with a DRC. Different analytical strategies including As oxidation and reactive removal of the interfering $\mathrm{ArCl}^{+}$species by ammonia, methane or hydrogen were investigated. It was not possible to reduce the spectral interference at $\mathrm{m} / \mathrm{z} 75$ sufficiently at this dilution factor with the cell pressurized with ammonia, methane or hydrogen. Satisfactory results were obtained by oxidation of $\mathrm{As}$ to $\mathrm{AsO}^{+}$and detection at $\mathrm{m} / \mathrm{z} 91$. Under optimised instrumental conditions, an LOD of $40 \mathrm{ng} \mathrm{L^{-1 }}$ As and precision of $2 \%$ were achieved. The accuracy of the method was verified by the analysis of NRCC CRMs NASS-4, CASS-4 and SLEW-3 and it was applied to the analysis of seawater samples from the Ross Sea in Antarctica. Other important polyatomic interferences $\left(\mathrm{ArC}^{+}\right.$and $\mathrm{ClOH}^{+}$) affect the determination of $\mathrm{Cr}$ at $\mathrm{m} / \mathrm{z} 52$, the most abundant (83.8\%) isotope of Cr. This particular application ${ }^{152}$ used an ICP-MS instrument with an ORS to detect $\mathrm{Cr}$ species at $\mathrm{m} / \mathrm{z} 52$ after ion chromatographic separation. Compared to the standard mode ORS operation, the use of $\mathrm{He}$ or $\mathrm{H}_{2}$ in the cell reduced the ${ }^{35} \mathrm{Cl}$ signal by more than 97 and $98 \%$ respectively. The optimum conditions used $\mathrm{H}_{2}$ in the cell and provided an LOD of $0.3 \mu \mathrm{g} \mathrm{L}^{-1}$. The developed method was used to determine the Cr oxidation states in waters containing high concentrations of chloride.

\subsubsection{Laser-induced breakdown spectroscopy}

The use of LIBS for the bulk analysis of water and as a remote sensing tool has highlighted significant areas of application for this technique. The measurement of seawater salinities by the determination of $\mathrm{Na}, \mathrm{Ca}$ and $\mathrm{Mg}$ using LIBS has been reported ${ }^{153}$. The plasma was generated by focusing a pulsed Nd:YAG laser on the seawater surface in air at atmospheric pressure. The emission spectrum was assessed using a wide-band fused-silica optical fibre, connected to a portable Echelle spectrometer with detection via a CCD camera. The electron temperature and density were determined from the emission intensity and used to calculate the seawater salinity. Lui et al. ${ }^{154}$ have used $\mu$-LIBS in combination with LIFS to measure $\mathrm{Pb}$ in drinking water. The sample was excited with a $170 \mu \mathrm{J}$ laser and the plasma created interrogated 
by a $10 \mu \mathrm{J}$ laser pulse tuned to a Pb resonance line, which achieved an effective LOD of $35 \mu \mathrm{g} \mathrm{\textrm {L } ^ { - }}$ 1 .

The determination of trace elements deposited on a surface using LIBS highlights ${ }^{155}$ another application area. Trace metals were electrically deposited on the surface of a polished high purity aluminium plate and then analysed by LIBS. After $10 \mathrm{~min}$ deposition at $36 \mathrm{~V}$ in 400 $\mathrm{mL}$ of the water sample, the LODs for $\mathrm{Cd}, \mathrm{Cr}, \mathrm{Cu}, \mathrm{Mn}, \mathrm{Pb}$ and $\mathrm{Zn}$ were 0.53, 0.57, 0.08, 0.37, 0.52 and $5.60 \mu \mathrm{g} \mathrm{L}^{-1}$ respectively; various natural water samples were analysed.

\subsection{Metrology and data quality}

Useful generic studies related to quality assurance and traceability have been published. Rienitz et al. ${ }^{156}$ have described a convenient and economic approach to achieving SI-traceable reference values for use in drinking water interlaboratory comparisons. Unlike consensus values, metrologically traceable reference values can be used to establish national and international comparability and add a significant benefit to interlaboratory comparisons. The developed approach used existing data collected during two national drinking water intercomparisons and derives the reference values from the amount of analyte added during sample preparation and the amount already present in the sample, in a similar way to a standard addition experiment. An uncertainty budget was calculated which describes the link to the corresponding SI unit. IDMS was used to validate the approach for $\mathrm{Cd}, \mathrm{Cr}, \mathrm{Cu}, \mathrm{Ni}$ and $\mathrm{Pb}$. A step-by-step example ${ }^{157}$ of how to calculate the combined uncertainty for the measurement of trace metals in seawater samples by GFAAS, using $\mathrm{Cu}$ as an example, has been published. The evaluation of measurement uncertainty results is not systematically implemented and so this paper is a useful starting point for the uninitiated. The major contributors to the overall uncertainty value included the amount of $\mathrm{Cu}$ in the sample and $\mathrm{CRM}$, the associated absorbance values and the auto-sampler volume. In a similar vein, Pino et al. ${ }^{158}$ have compiled an uncertainty budget for the determination of trace metals in seawater by GFAAS, except this method involves a classical 1pyrrolidinedithiocarbamate-diethyldithiocarbamate-freon extraction step. In this case the results showed that the greatest contribution to the overall combined uncertainty was the extraction method. 
Table 1 SPE applications used for sample preconcentration used in the analysis of water samples.. 


\begin{tabular}{|c|c|c|c|c|c|c|}
\hline Analytes & $\begin{array}{l}\text { Sample } \\
\text { Matrix }\end{array}$ & Substrate Coating & Column Substrate & $\begin{array}{l}\text { Detecto } \\
\text { r }\end{array}$ & Comment & Ref \\
\hline $\begin{array}{l}\mathrm{Ag}, \mathrm{Bi} \\
\mathrm{Cu}, \mathrm{Ga} \\
\mathrm{In}, \mathrm{Mo}, \\
\mathrm{Ni}, \mathrm{U}, \mathrm{V}\end{array}$ & $\begin{array}{l}\text { River and } \\
\text { sea waters }\end{array}$ & 3,4-dihydroxy benzoic acid & Chitosan resin & $\begin{array}{l}\text { ICP- } \\
\text { AES }\end{array}$ & $\begin{array}{l}\mathrm{LOD}\left(\mu \mathrm{g} \mathrm{L}{ }^{-1}\right): 0.08 \text { for } \mathrm{Ag} ; 0.9 \text { for } \\
\mathrm{Bi} ; 0.07 \text { for } \mathrm{Cu} ; 0.9 \text { for } \mathrm{Ga} ; 0.9 \text { for } \\
\mathrm{In} ; 0.08 \text { for } \mathrm{Mo} ; 0.09 \text { for } \mathrm{Ni} ; 0.9 \\
\text { for } \mathrm{U} ; 0.08 \text { for V. Enrichment } 8- \\
12 \text { fold. River water CRM SLRS- } \\
4 \text { and near shore seawater CASS- } \\
\text { 4, both NRCC. }\end{array}$ & 159 \\
\hline $\begin{array}{l}\mathrm{Ag}, \mathrm{Be}, \\
\mathrm{Cd}, \mathrm{Co}, \\
\mathrm{Cu}, \mathrm{Ni}, \\
\mathrm{Ph}, \mathrm{U}, \mathrm{V}, \\
\text { and } \\
\text { REEs }\end{array}$ & $\begin{array}{l}\text { Natural } \\
\text { water }\end{array}$ & 2-amino-5-hydroxy benzoic acid & $\begin{array}{l}\text { Cross-linked } \\
\text { chitosan }\end{array}$ & $\begin{array}{l}\text { ICP- } \\
\text { AES }\end{array}$ & $\begin{array}{l}\text { LOD in range } \mathrm{n} \mathrm{L}^{-1} \text { to } \mu \mathrm{g} \mathrm{L}^{-1} \text {. } \\
\text { Mini-column, installed into a } \\
\text { sequential-injection/automated } \\
\text { pretreatment system (Auto-Pret } \\
\text { System). River water CRM } \\
\text { SLRS-4 NRCC. }\end{array}$ & 160 \\
\hline $\mathrm{As}^{\mathrm{III}}$ & $\begin{array}{l}\text { Natural } \\
\text { water }\end{array}$ & Ammonium pyrrolidinedithiocarbamate. & Activated carbon & GFAAS & $\begin{array}{l}\text { LOD } 50 \mathrm{ng} \mathrm{L}^{-1} \text {. Enrichment factor } \\
\text { 50. Specific adsorption of } \mathrm{As}^{\mathrm{III}} \text { at } \\
\text { pH } 1.8-3.0 \text {. Elution with } 0.1 \mathrm{M} \\
\text { nitric acid. Quantitative spike }\end{array}$ & 161 \\
\hline
\end{tabular}




\begin{tabular}{|c|c|c|c|c|c|c|}
\hline & & & & & recovery. & \\
\hline $\begin{array}{l}\mathrm{As}^{\mathrm{III}} \\
\mathrm{As}^{\mathrm{V}} \\
\mathrm{Sb}^{\mathrm{III}}, \mathrm{Sb}^{\mathrm{V}}\end{array}$ & $\begin{array}{l}\text { Natural } \\
\text { water }\end{array}$ & Dimercaptosuccinic acid & Mesoporous $\mathrm{TiO}_{2}$ & $\begin{array}{l}\text { ICP- } \\
\text { AES }\end{array}$ & $\begin{array}{l}\mathrm{LOD}\left(\mu \mathrm{L}^{-1}\right): 0.53 \text { for } \mathrm{As}^{\mathrm{III}} ; 0.49 \\
\text { for } \mathrm{As}^{\mathrm{V}} ; 0.77 \text { for } \mathrm{Sb}^{\mathrm{III}} ; 0.71 \text { for } \\
\mathrm{Sb}^{\mathrm{V}} . \text { Enrichment factor } 10 . \\
\text { Speciation of oxidation states } \\
\text { using change in } \mathrm{pH} . \text { Oxidation } \\
\text { state (III) adsorbed at pH } 10-11 \text {, } \\
\text { (V) at } \mathrm{pH} 4-7 . \text { Water CRMs } \\
\text { GSBZ5004-88 and GBW(E) } \\
080545 .\end{array}$ & 162 \\
\hline $\mathrm{Au}$ & $\begin{array}{l}\text { Natural } \\
\text { water }\end{array}$ & p-Dimethylaminobenzlidenerhodanine. & Nanometer $\mathrm{TiO}_{2}$ & FAAS & $\begin{array}{l}\text { LOD } 2.34 \mu \mathrm{g} \mathrm{L}^{-1} \text {. Adsorption at } \\
\mathrm{pH} 3.5 \text {. Elution with } 0.1 \mathrm{M} \mathrm{HCl}- \\
0.5 \mathrm{M} \text { thiourea. Quantitative spike } \\
\text { recovery. }\end{array}$ & 163 \\
\hline $\mathrm{Au}^{\mathrm{III}}$ & Sea water & $\mathrm{n} / \mathrm{a}$ & $\begin{array}{l}\text { Amberlite XAD- } \\
2000\end{array}$ & FAAS & $\begin{array}{l}\text { LOD } 2 \mu \mathrm{g} \mathrm{L}^{-1} \text {. Retention as } \\
\text { chloro-complex. Recovery from } \\
\text { spiked seawater } 100 \% \text {. }\end{array}$ & 164 \\
\hline $\mathrm{Bi}$ & $\begin{array}{l}\text { Natural } \\
\text { water }\end{array}$ & $\mathrm{n} / \mathrm{a}$ & Nylon fibre & HGAFS & $\begin{array}{l}\text { LOD } 2.8 \mathrm{ng} \mathrm{L}^{-1} \text {. Enrichment } \\
\text { factor 20. Retention as Bismuthiol }\end{array}$ & 165 \\
\hline
\end{tabular}




\begin{tabular}{|c|c|c|c|c|c|c|}
\hline & & & & & I. complex. & \\
\hline $\begin{array}{l}\mathrm{Bi}, \mathrm{Cd}, \\
\mathrm{Cu}, \mathrm{Hg}, \\
\mathrm{Pb}, \mathrm{Pd}, \\
\mathrm{Zn}\end{array}$ & Sea water & $\mathrm{n} / \mathrm{a}$ & Hollow-fibre & $\begin{array}{l}\text { ETV- } \\
\text { ICPMS }\end{array}$ & $\begin{array}{l}\mathrm{LOD}\left(\mathrm{ng} \mathrm{L}^{-1}\right): 1.6 \text { for } \mathrm{Bi} ; 4.5 \text { for } \\
\mathrm{Cd} ; 12.4 \text { for } \mathrm{Cu} ; 3.3 \text { for } \mathrm{Hg} ; 4.8 \\
\text { for } \mathrm{Pb} ; 7.9 \text { for } \mathrm{Pd} ; 28.7 \text { for } \mathrm{Zn} \text {. } \\
\text { Enrichment factor } 20-300 . \\
\text { Adsorption as DDTC complexes, } \\
\text { DDTC acting as matrix modifier. } \\
\text { GBW(E)080040 seawater CRM. }\end{array}$ & 166 \\
\hline $\mathrm{Cd}$ & Sea water & Methyl thymol blue & Activated carbon & FAAS & $\begin{array}{l}\text { LOD } 1.0 \mu \mathrm{g} \mathrm{L}^{-1} \text {. Enrichment } \\
\text { factor } 1000 \text { at } \mathrm{pH} 9.0 \text {. Near shore } \\
\text { seawater CASS-4, NRCC. }\end{array}$ & 167 \\
\hline $\mathrm{Cd}$ & Sea water & $\mathrm{NaBH}_{4}$ & Knotted reactor & HGAFS & $\begin{array}{l}\text { LOD } 3.2 \mathrm{ng} \mathrm{L}^{-1} \text {. Enrichment } \\
\text { factor 12. Adsorption as 1- } \\
\text { Phenyl-3-methyl-4- } \\
\text { benzoylpyrazol-5-one complex at } \\
\text { pH 3. Elution with } 0.2 \mathrm{M} \mathrm{HCl} \text {. }\end{array}$ & 168 \\
\hline $\mathrm{Cd}$ & $\begin{array}{l}\text { Natural } \\
\text { water }\end{array}$ & $\mathrm{n} / \mathrm{a}$ & $\begin{array}{l}\text { Poly- } \\
\text { chlorotrifluoroethyl } \\
\text { ene }\end{array}$ & FAAS & $\begin{array}{l}\text { LOD } 0.3 \mu \mathrm{g} \mathrm{L}^{-1} \text {. Enrichment } \\
\text { factor } 39 . \text { Adsorption as } \\
\text { diethyldithiophosphate complex. }\end{array}$ & 169 \\
\hline
\end{tabular}




\begin{tabular}{|c|c|c|c|c|c|c|}
\hline & & & & & $\begin{array}{l}\text { Elution with isobutyl } \\
\text { methylketone. NIST } 1643 \mathrm{~d} \text { water } \\
\text { CRM. }\end{array}$ & \\
\hline $\mathrm{Cd}$ & Seawater & Xylenol orange & Activated carbon & FAAS & $\begin{array}{l}\text { LOD } 0.3 \mu \mathrm{g} \mathrm{L}^{-1} \text {. Enrichment } \\
\text { factor } 200 \text {. Elution with } 0.5 \mathrm{M} \\
\text { nitric acid. Near shore seawater } \\
\text { CASS-4, NRCC. }\end{array}$ & 170 \\
\hline $\mathrm{Cd}$ & $\begin{array}{l}\text { Natural } \\
\text { water }\end{array}$ & $\mathrm{n} / \mathrm{a}$ & $\begin{array}{l}\text { Multiwalled carbon } \\
\text { nanotubes } \\
(\mathrm{MWCN}) \text {. }\end{array}$ & FAAS & $\begin{array}{l}\text { LOD } 0.15 \mu \mathrm{g} \mathrm{L}^{-1} . \text { MWCN tubes } \\
\text { pretreated with potassium } \\
\text { permanganate. }\end{array}$ & 171 \\
\hline $\mathrm{Cd}$ & $\begin{array}{l}\text { River and } \\
\text { sea water }\end{array}$ & $\mathrm{NaBH}_{4}$ & $\begin{array}{l}\text { Cellulose fibre } \\
\text { microcolumn }\end{array}$ & HGAFS & $\begin{array}{l}\text { LOD } 3 \mathrm{ng} \mathrm{L}^{-1} \text {. Enrichment factor } \\
\text { 20. In situ vapour generation after } \\
\text { elution with } \mathrm{HCl} \text {. River water } \\
\text { CRM SLRS-4 NRCC, trace } \\
\text { elements in water GBW } 08608 \text {. }\end{array}$ & 172 \\
\hline $\mathrm{Cd}$ & Sea water & $\mathrm{n} / \mathrm{a}$ & $\begin{array}{l}\text { Custom prepared } \\
\text { alkyl phosphinic } \\
\text { acid resin }\end{array}$ & $\begin{array}{l}\text { VG- } \\
\text { AFS }\end{array}$ & $\begin{array}{l}\text { LOD } 2.67 \mathrm{ng} \mathrm{L}^{-1} \text {. Enrichment } \\
\text { factor 189. Sample vol. } 200 \mathrm{~mL} \text {. }\end{array}$ & 173 \\
\hline $\mathrm{Cd}, \mathrm{Cu}$ & Stream, & Bismuthiol I & Pulverized & FAAS & $\operatorname{LOD}\left(\mu \mathrm{g} \mathrm{L}^{-1}\right): 0.3$ for $\mathrm{Cd} ; 1.0$ for & 174 \\
\hline
\end{tabular}




\begin{tabular}{|c|c|c|c|c|c|c|}
\hline & $\begin{array}{l}\text { reservoir, tap } \\
\text { and waste } \\
\text { waters }\end{array}$ & & Amberlite XAD-4 & & Cu. Quantitative spike recovery. & \\
\hline $\begin{array}{l}\mathrm{Cd}, \mathrm{Cu}, \\
\mathrm{Pb}\end{array}$ & $\begin{array}{l}\text { Drinking } \\
\text { water }\end{array}$ & Procion Red MX-3B & $\begin{array}{l}\text { Poly(ethylene } \\
\text { glycol } \\
\text { dimethacrylate } \\
\text { hdroxyethyl } \\
\text { methacrylate } \\
\text { microbeads. }\end{array}$ & FAAS & $\begin{array}{l}\mathrm{LOD}\left(\mu \mathrm{L} \mathrm{L}^{-1}\right): 0.5 \text { for } \mathrm{Cd} ; 1.25 \text { for } \\
\mathrm{Cu} ; 10 \text { for } \mathrm{Pb} \text {. Enrichment factor } \\
\text { 50. Elution with } 0.2 \mathrm{M} \text { nitric acid. } \\
\text { SPS-SW2 surface water and LGC } \\
6010 \text { hard drinking water CRMs. }\end{array}$ & 175 \\
\hline $\begin{array}{l}\mathrm{Cd}, \mathrm{Cu}, \\
\mathrm{Ni}, \mathrm{Pb}\end{array}$ & $\begin{array}{l}\text { Natural } \\
\text { water }\end{array}$ & Gallic acid & Silca gel & FAAS & $\begin{array}{l}\mathrm{LOD}\left(\mu \mathrm{g} \mathrm{L}^{-1}\right): 0.65 \text { for } \mathrm{Cd} ; 0.86 \\
\text { for } \mathrm{Cu} ; 0.92 \text { for } \mathrm{Ni} ; 0.58 \text { for } \mathrm{Pb} \text {. } \\
\text { Enrichment factor } 200 .\end{array}$ & 176 \\
\hline $\begin{array}{l}\mathrm{Cd}, \mathrm{Co}, \\
\mathrm{Cu}, \mathrm{Ni} \\
\mathrm{Pb}, \mathrm{Zn} .\end{array}$ & $\begin{array}{l}\text { Drinking } \\
\text { water }\end{array}$ & $\mathrm{n} / \mathrm{a}$ & $\begin{array}{l}\text { Multiwalled carbon } \\
\text { nanotubes } \\
(\mathrm{MWCNT})\end{array}$ & FAAS & $\begin{array}{l}\text { LOD in range } 0.3-0.6 \mu \mathrm{g} \mathrm{L}^{-1} \text {. } \\
\text { Adsorption as pyrrolidine } \\
\text { dithiocarbamate chelates. LGC } \\
6010 \text { hard drinking water CRM. }\end{array}$ & 177 \\
\hline $\begin{array}{l}\mathrm{Cd}, \mathrm{Co}, \\
\mathrm{Cu}, \mathrm{Ni} \\
\mathrm{Pb}, \mathrm{V}\end{array}$ & $\begin{array}{l}\text { Tap, ground } \\
\text { and sea } \\
\text { waters. }\end{array}$ & Niobium(V)oxide. & Silica gel & ICP-MS & $\begin{array}{l}\text { LOD in range } 0.01-0.03 \mu \mathrm{g}^{-1} \text {. } \\
\text { Adsorption at } \mathrm{pH} 7 . \text { Elution with } \\
2.5 \mathrm{M} \text { nitric acid. Near shore }\end{array}$ & 178 \\
\hline
\end{tabular}




\begin{tabular}{|c|c|c|c|c|c|c|}
\hline $\mathrm{Zn}$ & & & & & $\begin{array}{l}\text { seawater CASS-4, NASS-4 and } \\
\text { NASS-5 all NRCC. SRM 1643e. }\end{array}$ & \\
\hline $\begin{array}{l}\mathrm{Cd}, \mathrm{Co}, \\
\mathrm{Cr}, \mathrm{Cu}, \\
\mathrm{Fe}^{\mathrm{III}}, \mathrm{Mn}, \\
\mathrm{Ni}, \mathrm{Pb}\end{array}$ & $\begin{array}{l}\text { Well and } \\
\text { lake waters. }\end{array}$ & Thiosalicylic acid & $\begin{array}{l}\text { Amberlite XAD- } \\
1180\end{array}$ & FAAS & $\begin{array}{l}\mathrm{LOD}\left(\mu \mathrm{g} \mathrm{L}{ }^{-1}\right): 0.22 \text { for } \mathrm{Cd} ; 1.16 \\
\text { for } \mathrm{Co} ; 1.60 \text { for } \mathrm{Cr}, 0.91 \text { for } \mathrm{Cu} \text {; } \\
2.76 \text { for } \mathrm{Fe} ; 0.76 \text { for } \mathrm{Mn} ; 1.24 \text { for } \\
\mathrm{Ni} ; 3.18 \text { for } \mathrm{Pb} \text {. Enrichment factor } \\
15-18 . \text { Lake water CRM TMDA } \\
-62 .\end{array}$ & 179 \\
\hline $\begin{array}{l}\mathrm{Cd}, \mathrm{Co}, \\
\mathrm{Cu}, \mathrm{Fe}, \\
\mathrm{Mn}, \mathrm{Ni} \\
\mathrm{Pb}, \mathrm{Zn}\end{array}$ & $\begin{array}{l}\text { Natural } \\
\text { water }\end{array}$ & $\mathrm{n} / \mathrm{a}$ & $\begin{array}{l}\text { Amberlite XAD- } \\
2010\end{array}$ & FAAS & $\begin{array}{l}\text { LOD } 0.1-0.4 \mu \mathrm{g} \mathrm{L}^{-1} .8- \\
\text { Hydroxyquinoline complex } \\
\text { adsorbed. TMDW-500 drinking } \\
\text { water CRM. }\end{array}$ & 180 \\
\hline $\begin{array}{l}\mathrm{Cd}, \mathrm{Co}, \\
\mathrm{Cu}, \mathrm{Fe}, \\
\mathrm{Mn}, \mathrm{Ni} \\
\mathrm{Pb}, \mathrm{Zn}\end{array}$ & $\begin{array}{l}\text { Natural } \\
\text { water }\end{array}$ & $\mathrm{n} / \mathrm{a}$ & $\begin{array}{l}\text { Amberlite XAD- } \\
2000\end{array}$ & FAAS & $\begin{array}{l}\mathrm{LOD}\left(\mu \mathrm{g} \mathrm{L}^{-1}\right): 0.20 \text { for } \mathrm{Cd} ; 0.25 \\
\text { for } \mathrm{Co} ; 0.20 \text { for } \mathrm{Cu} ; 0.35 \text { for } \mathrm{Fe} \text {; } \\
0.20 \text { for } \mathrm{Mn} ; 0.25 \text { for } \mathrm{Ni} ; 0.45 \text { for } \\
\mathrm{Pb} ; 0.15 \text { for } \mathrm{Zn} \text {. }\end{array}$ & 181 \\
\hline $\begin{array}{l}\mathrm{Cd}, \mathrm{Co}, \\
\mathrm{Cu}, \mathrm{Fe}, \\
\mathrm{Mn}, \mathrm{Ni}\end{array}$ & River water & 2,3-Dihydroxypyridine & Amberlite XAD-16 & FAAS & $\begin{array}{l}\mathrm{LOD}\left(\mu \mathrm{g} \mathrm{L}^{-1}\right): 1.91 \text { for } \mathrm{Cd} ; 5.02 \\
\text { for } \mathrm{Co} ; 1.63 \text { for } \mathrm{Cu} ; 4.59 \text { for } \mathrm{Fe} \text {; } \\
3.80 \text { for } \mathrm{Mn} ; 5.17 \text { for } \mathrm{Ni} ; 7.02 \text { for }\end{array}$ & 182 \\
\hline
\end{tabular}




\begin{tabular}{|c|c|c|c|c|c|c|}
\hline $\mathrm{Pb}, \mathrm{Zn}$ & & & & & $\begin{array}{l}\mathrm{Pb} ; 2.90 \text { for } \mathrm{Zn} . \text { Enrichment } \\
\text { factors between } 200-300 \text {. } \\
\text { Adsorption at } \mathrm{pH} 4-6.5 \text {. }\end{array}$ & \\
\hline $\begin{array}{l}\mathrm{Cd}, \mathrm{Ce}, \\
\mathrm{Co}, \mathrm{Cr}, \\
\mathrm{Cu}, \mathrm{Dy}, \\
\mathrm{Eu}, \mathrm{La}, \\
\mathrm{Mn}, \mathrm{Ni}, \\
\mathrm{V}, \mathrm{Yb}\end{array}$ & $\begin{array}{l}\text { Natural } \\
\text { water }\end{array}$ & $\mathrm{n} / \mathrm{a}$ & Mesoporous $\mathrm{TiO}_{2}$ & $\begin{array}{l}\text { ICP- } \\
\text { AES }\end{array}$ & $\begin{array}{l}\text { LOD in range } 0.03-0.36 \mu \mathrm{g} \mathrm{L}^{-1} \text {. } \\
\text { Enrichment factor } 10 . \text { Micro- } \\
\text { column. }\end{array}$ & 183 \\
\hline $\begin{array}{l}\mathrm{Co}, \mathrm{Cu}, \\
\mathrm{Ni}\end{array}$ & $\begin{array}{l}\text { Tap, river } \\
\text { and sea } \\
\text { waters }\end{array}$ & Dithioxamide & Activated carbon & FAAS & $\begin{array}{l}\mathrm{LOD}\left(\mu \mathrm{g} \mathrm{L}^{-1}\right): 0.80 \text { for } \mathrm{Co} ; 0.50 \\
\text { for } \mathrm{Cu} ; 0.75 \text { for Ni. Enrichment } \\
\text { factor 330. Adsorption at } \mathrm{pH} 5.5 \text {. }\end{array}$ & 184 \\
\hline $\begin{array}{l}\mathrm{Co}, \mathrm{Mn}, \\
\mathrm{Ni}\end{array}$ & $\begin{array}{l}\text { Natural } \\
\text { water }\end{array}$ & $\mathrm{n} / \mathrm{a}$ & Carbon nanofibers & ICP-MS & $\begin{array}{l}\mathrm{LOD}\left(\mu \mathrm{g} \mathrm{L}^{-1}\right): 0.4 \text { for } \mathrm{Co} ; 40 \text { for } \\
\mathrm{Mn} ; 8 \text { for Ni. Enrichment factor } \\
\text { 150. Adsorption in } \mathrm{pH} \text { range } 6- \\
\text { 9. Elution with } 0.5 \mathrm{M} \text { nitric acid. } \\
\text { Quantitative spike recovery. }\end{array}$ & 185 \\
\hline $\begin{array}{l}\mathrm{Co}, \mathrm{Cr} \\
\mathrm{Cu}, \mathrm{Mn}\end{array}$ & Lake water & $\mathrm{n} / \mathrm{a}$ & Zirconium dioxide & $\begin{array}{l}\text { ICP- } \\
\text { AES }\end{array}$ & $\begin{array}{l}\mathrm{LOD}\left(\mathrm{ng} \mathrm{L}^{-1}\right): 36 \text { for } \mathrm{Co} ; 24 \text { for } \\
\mathrm{Cr} ; 58 \text { for } \mathrm{Cu} ; 12 \text { for } \mathrm{Mn} ; 7 \text { for } \mathrm{Ni} \text {; }\end{array}$ & 186 \\
\hline
\end{tabular}




\begin{tabular}{|c|c|c|c|c|c|c|}
\hline $\mathrm{Ni}, \mathrm{Zn}$ & & & & & $\begin{array}{l}2 \text { for } Z n . . \text { Enrichment factor } 25 \text {. } \\
\text { Microcolumn } 20 \times 2 \mathrm{~mm} \text {. }\end{array}$ & \\
\hline $\mathrm{Cr}$ & $\begin{array}{l}\text { Natural } \\
\text { water }\end{array}$ & $\mathrm{n} / \mathrm{a}$ & Granular calcite & GFAAS & $\begin{array}{l}\mathrm{LOD} 0.8 \mu \mathrm{g} \mathrm{L}^{-1} \cdot \mathrm{Cr}^{\mathrm{VI}} \\
\text { determination after } \mathrm{Cr}^{\mathrm{III}} \text { adsorbed } \\
\text { onto column at } \mathrm{pH} 5.5 . \text { Total } \mathrm{Cr} \\
\text { after reduction with ascorbic acid, } \\
\text { speciation by difference }\end{array}$ & 187 \\
\hline $\mathrm{Cr}^{\mathrm{III}}$ & $\begin{array}{l}\text { Natural } \\
\text { water }\end{array}$ & $\mathrm{n} / \mathrm{a}$ & $\begin{array}{l}\text { Surface imprinted } \\
\text { aminopropyl silica } \\
\text { gel }\end{array}$ & $\begin{array}{l}\text { ICP- } \\
\text { AES }\end{array}$ & $\begin{array}{l}\text { LOD } 0.11 \mu \mathrm{g} \mathrm{L}^{-1} \text {. Total } \mathrm{Cr} \text { after } \\
\text { reduction with hydroxyammonium } \\
\text { chloride, speciation by difference. }\end{array}$ & 188 \\
\hline $\mathrm{Cr}^{\mathrm{III}}$ & $\begin{array}{l}\text { Natural } \\
\text { water }\end{array}$ & $\mathrm{n} / \mathrm{a}$ & $\begin{array}{l}\text { Surface imprinted } \\
\text { silica gel }\end{array}$ & ICP-MS & $\begin{array}{l}\text { LOD } 4.43 \mathrm{ng} \mathrm{L}^{-1} \text {. Enrichment } \\
\text { factor } 700 . \mathrm{Cr}^{\mathrm{VI}} \text { adsorbed at low } \\
\text { pH, speciation by difference. } \\
\text { Quantitative spike recovery. }\end{array}$ & 189 \\
\hline $\mathrm{Cr}^{\mathrm{III}}$ & $\begin{array}{l}\text { Electroplatin } \\
\mathrm{g} \text { waste } \\
\text { water }\end{array}$ & 8-Hydroxyquinoline & Alumina & FAAS & $\begin{array}{l}\text { Enrichment factor } 98 \text {. Total } \mathrm{Cr} \\
\text { after reduction with } \\
\text { hydroxylamine, speciation by } \\
\text { difference. }\end{array}$ & 190 \\
\hline $\mathrm{Cr}^{\mathrm{III}}$ & River water & $\mathrm{n} / \mathrm{a}$ & Chelex-100 & ICP-MS & NRCC CASS-2 CRM. Used off- & 191 \\
\hline
\end{tabular}




\begin{tabular}{|c|c|c|c|c|c|c|}
\hline & & & & & $\begin{array}{l}\text { line for speciation analysis after } \\
\text { total Cr analysis; speciation by } \\
\text { difference. }\end{array}$ & \\
\hline $\mathrm{Cr}^{\mathrm{VI}}$ & $\begin{array}{l}\text { Drinking } \\
\text { water }\end{array}$ & $\mathrm{n} / \mathrm{a}$ & $\begin{array}{l}\text { Amberlite XAD- } \\
2010\end{array}$ & FAAS & $\begin{array}{l}\text { LOD } 1.28 \mu \mathrm{g} \mathrm{L}^{-1} \text {. Enrichment } \\
\text { factor } 25 \text {. Diethyldithiocarbamate } \\
\text { complex adsorbed at } \mathrm{pH} 2-3 \text {. } \\
\text { TMDW-500 drinking water CRM. }\end{array}$ & 192 \\
\hline $\mathrm{Cr}^{\mathrm{VI}}$ & $\begin{array}{l}\text { Natural } \\
\text { water }\end{array}$ & $\mathrm{n} / \mathrm{a}$ & $\begin{array}{l}\text { Amberlite XAD- } \\
1180\end{array}$ & FAAS & $\begin{array}{l}\text { LOD } 8.6 \mu \mathrm{g} \mathrm{L}^{-1} \text {. Enrichment } \\
\text { factor } 75 \text {. Diphenylcarbazone } \\
\text { complex adsorbed. Total Cr after } \\
\text { oxidation, speciation by } \\
\text { difference. }\end{array}$ & 193 \\
\hline $\mathrm{Cr}^{\mathrm{VI}}$ & $\begin{array}{l}\text { Natural } \\
\text { water }\end{array}$ & $\mathrm{n} / \mathrm{a}$ & $\begin{array}{l}\text { Multiwalled carbon } \\
\text { nanotubes } \\
(\mathrm{MWCN}) .\end{array}$ & FAAS & $\begin{array}{l}\text { LOD } 0.9 \mu \mathrm{g} \mathrm{L}^{-1} \text {. Ammonium } \\
\text { pyrrolidine dithiocarbamate } \\
\text { complex adsorbed. Total Cr after } \\
\text { oxidation with hydrogen peroxide, } \\
\text { speciation by difference. }\end{array}$ & 194 \\
\hline $\mathrm{Cr}^{\mathrm{VI}}$ & $\begin{array}{l}\text { Natural } \\
\text { water }\end{array}$ & $\mathrm{n} / \mathrm{a}$ & Dowex M4195 & FAAS & $\begin{array}{l}\text { Total Cr after oxidation with } \\
\text { hydrogen peroxide, speciation by }\end{array}$ & 195 \\
\hline
\end{tabular}




\begin{tabular}{|c|c|c|c|c|c|c|}
\hline & & & & & $\begin{array}{l}\text { difference. Quantitative spike } \\
\text { recovery. }\end{array}$ & \\
\hline $\mathrm{Cr}^{\mathrm{VI}}$ & $\begin{array}{l}\text { Stream, tap } \\
\text { and mineral } \\
\text { waters }\end{array}$ & $\mathrm{n} / \mathrm{a}$ & $\begin{array}{l}\text { Amberlite XAD- } \\
2000\end{array}$ & FAAS & $\begin{array}{l}\text { LOD } 0.60 \mu \mathrm{g} \mathrm{L}^{-1} \text {. Enrichment } \\
\text { factor } 80 \text { for } 200 \mathrm{~mL} \text { sample vol. } \\
\text { Pyrrolidinedithiocarbamate } \\
\text { complex adsorbed at } \mathrm{pH} 1.5-2.5 \text {. } \\
\text { Total Cr after oxidation with } \\
\text { potassium permanganate, } \\
\text { speciation by difference. TMDW- } \\
500 \text { drinking water CRM. }\end{array}$ & 196 \\
\hline $\begin{array}{l}\mathrm{Cr}^{\mathrm{III}}, \\
\mathrm{Cu}^{\mathrm{II}}, \mathrm{Ni}^{\mathrm{II}}, \\
\mathrm{Pb}^{\mathrm{II}}, \mathrm{Zn}^{\mathrm{II}}\end{array}$ & $\begin{array}{l}\text { Natural } \\
\text { water }\end{array}$ & p-Dimethylaminobenzaldehyde & Silica gel & $\begin{array}{l}\text { ICP- } \\
\text { AES }\end{array}$ & $\begin{array}{l}\mathrm{LOD}\left(\mu \mathrm{L} \mathrm{L}^{-1}\right): 1.1 \text { for } \mathrm{Cr} ; 0.69 \text { for } \\
\mathrm{Cu} ; 0.99 \text { for } \mathrm{Ni} ; 1.1 \text { for } \mathrm{Pb} ; 6.5 \text { for } \\
\mathrm{Zn} . \text { Enrichment factor } 125 \text {. } \\
\text { Adsorption at } \mathrm{pH} 4.0 \text {. }\end{array}$ & 197 \\
\hline $\mathrm{Cu}$ & $\begin{array}{l}\text { Natural } \\
\text { water }\end{array}$ & 1,5-Diphenylcarbazide & $\begin{array}{l}\text { Octadecyl silica } \\
\text { membrane disks }\end{array}$ & FAAS & $\begin{array}{l}\text { LOD } 5 \mathrm{ng} \mathrm{L}^{-1} \text {. Enrichment factor } \\
400 \text {. }\end{array}$ & 198 \\
\hline $\mathrm{Cu}$ & $\begin{array}{l}\text { Natural } \\
\text { water }\end{array}$ & N,N'-Disalicylideneethylenediamine & $\begin{array}{l}\text { Octadecyl-bonded } \\
\text { silica membrane } \\
\text { disks (ENVI-18) }\end{array}$ & FAAS & $\begin{array}{l}\text { LOD } 5 \mathrm{ng} \mathrm{L}^{-1} \text {. Enrichment factor } \\
\text { 500. Elution with organic solvent. }\end{array}$ & 199 \\
\hline
\end{tabular}




\begin{tabular}{|c|c|c|c|c|c|c|}
\hline $\mathrm{Cu}^{\mathrm{II}}$ & $\begin{array}{l}\text { Stream, } \\
\text { reservoir and } \\
\text { waste waters }\end{array}$ & N-benzoylphenylhydroxylamine & $\begin{array}{l}\text { Pulverized } \\
\text { Amberlite XAD-4 }\end{array}$ & FAAS & $\begin{array}{l}\text { LOD } 0.83 \mu \mathrm{g} \mathrm{L}^{-1} \text {. Quantitative } \\
\text { spike recovery. }\end{array}$ & 200 \\
\hline $\mathrm{Cu}, \mathrm{Ni}$ & $\begin{array}{l}\text { River and } \\
\text { synthetic sea } \\
\text { water. }\end{array}$ & Triethylenetetramine & Silica gel & FAAS & $\begin{array}{l}\mathrm{LOD}\left(\mu \mathrm{g} \mathrm{L}^{-1}\right): 0.36 \text { for } \mathrm{Cu} ; 0.22 \\
\text { for Ni. Elution with } \mathrm{HCl} \text {. } \\
\text { Quantitative spike recovery. }\end{array}$ & 201 \\
\hline $\mathrm{Cu}, \mathrm{Pb}$ & $\begin{array}{l}\text { Natural } \\
\text { waters }\end{array}$ & Phenytoin, thiophenytoin or thiophenole. & Activated carbon & FAAS & $\begin{array}{l}\mathrm{LOD}\left(\mu \mathrm{g} \mathrm{L}^{-1}\right) 0.31-0.42,0.37- \\
0.65 \text {, depending on substrate } \\
\text { coating. Quantitative spike } \\
\text { recovery. }\end{array}$ & 202 \\
\hline $\begin{array}{l}\mathrm{Cu}, \mathrm{Fe}^{\mathrm{III}}, \\
\mathrm{Zn}\end{array}$ & River water & $\begin{array}{l}\text { 2,2'-[ethane-1,2- } \\
\text { diylbis(nitrilomethylidyne)]bis(2- } \\
\text { methylphenol) }\end{array}$ & Agarose support & FAAS & $\begin{array}{l}\mathrm{LOD}\left(\mu \mathrm{g} \mathrm{L}^{-1}\right): 0.31 \text { for } \mathrm{Cu} ; 1.73 \\
\text { for } \mathrm{Fe}^{\mathrm{III}} ; 0.16 \text { for } \mathrm{Zn} \text {. Enrichment } \\
\text { factor } 100 . \text { Quantitative spike } \\
\text { recovery at pH } 5.5-6.5 \text {. }\end{array}$ & 203 \\
\hline $\begin{array}{l}\mathrm{Cu}, \mathrm{Mo}, \\
\mathrm{V}\end{array}$ & $\begin{array}{l}\text { Natural } \\
\text { water. }\end{array}$ & Threonine & $\begin{array}{l}\text { Chitosan-based } \\
\text { resin. }\end{array}$ & $\begin{array}{l}\text { ICP- } \\
\text { AES }\end{array}$ & $\begin{array}{l}\text { LOD all less than } 1 \mu \mathrm{g} \mathrm{L}^{-1} \text {. } \\
\text { Elution with } 2 \mathrm{M} \text { nitric acid. } \\
\text { Quantitative spike recovery. }\end{array}$ & 204 \\
\hline $\begin{array}{l}\mathrm{Cu}, \mathrm{Mn}, \\
\mathrm{Pb}, \mathrm{Zn}\end{array}$ & $\begin{array}{l}\text { Tap, } \\
\text { reservoir and }\end{array}$ & $\mathrm{n} / \mathrm{a}$ & $\begin{array}{l}\text { Multi-walled } \\
\text { carbon nanotubes }\end{array}$ & FAAS & $\begin{array}{l}\mathrm{LOD}\left(\mu \mathrm{g} \mathrm{L}^{-1}\right): 0.47 \text { for } \mathrm{Cu} ; 0.71 \\
\text { for } \mathrm{Mn} ; 0.28 \text { for } \mathrm{Pb} ; 0.87 \text { for } \mathrm{Zn} \text {. }\end{array}$ & 205 \\
\hline
\end{tabular}




\begin{tabular}{|c|c|c|c|c|c|c|}
\hline & $\begin{array}{l}\text { stream } \\
\text { waters. }\end{array}$ & & $(\mathrm{MWCNT})$ & & $\begin{array}{l}\text { Adsorption at pH 9. Quantitative } \\
\text { spike recovery. }\end{array}$ & \\
\hline $\mathrm{Fe}^{\mathrm{III}}$ & $\begin{array}{l}\text { Natural } \\
\text { water }\end{array}$ & 2-Mercaptopyridine-1-oxide & $\begin{array}{l}\text { Octadecyl silica } \\
\text { membrane disks }\end{array}$ & FAAS & $\begin{array}{l}\text { LOD } 0.63 \mu \mathrm{g} \mathrm{L}^{-1} \text {. Enrichment } \\
\text { factor 166. Quantitative spike } \\
\text { recovery. }\end{array}$ & 206 \\
\hline $\mathrm{Hg}$ & Sea water & $\mathrm{NaBH}_{4}$ & $\begin{array}{l}\text { Various synthetic } \\
\text { materials }\end{array}$ & AFS & $\begin{array}{l}\text { LOD } 5 \mathrm{ng} \mathrm{L}^{-1} \text {. PTFE, PEEK, } \\
\text { Excelon, fluorinated ethylene } \\
\text { propylene (FEP) substrates tested. } \\
\text { Vapour generation sample } \\
\text { introduction. }\end{array}$ & 207 \\
\hline $\mathrm{Hg}$ & $\begin{array}{l}\text { River and } \\
\text { mineral } \\
\text { waters. }\end{array}$ & Dithiozone & Nanometer $\mathrm{TiO}_{2}$ & CVAAS & $\begin{array}{l}\text { LOD } 5 \mathrm{ng} \mathrm{L}^{-1} \text {. Adsorption at } \mathrm{pH} 7 \\
-8 . \text { Elution with } 3.5 \mathrm{M} \mathrm{HCl} \text {. } \\
\text { Quantitative spike recovery. }\end{array}$ & 208 \\
\hline $\mathrm{Hg}^{\mathrm{II}}$ & $\begin{array}{l}\text { Natural } \\
\text { water }\end{array}$ & Diaminothiourea & Silica gel & CVAAS & $\begin{array}{l}\text { LOD } 0.28 \mu \mathrm{g} \mathrm{L}^{-1} \text {. Adsorption at } \\
\mathrm{pH} 2 \text {. }\end{array}$ & 209 \\
\hline Mo & $\begin{array}{l}\text { Drinking } \\
\text { water }\end{array}$ & $\mathrm{n} / \mathrm{a}$ & $\begin{array}{l}\text { Ethylvinyl acetate } \\
\text { turnings }\end{array}$ & $\begin{array}{l}\text { ICP- } \\
\text { OES }\end{array}$ & $\begin{array}{l}\text { LOD } 0.04 \mu \mathrm{g} \mathrm{L}^{-1} \text {. Enrichment } \\
\text { factor } 300 \text {. Metals in natural } \\
\text { water, NIST CRM } 1643 \mathrm{e} \text {. }\end{array}$ & 210 \\
\hline $\mathrm{Ni}$ & Waste water & 2[2-Mercaptophenylimino)methyl]phenol & Octadecyl silica & FAAS & LOD $0.17 \mu \mathrm{g} \mathrm{L}^{-1}$. Enrichment & 211 \\
\hline
\end{tabular}




\begin{tabular}{|c|c|c|c|c|c|c|}
\hline & & & membrane disk & & $\begin{array}{l}\text { factor } 400 . \text { Quantitative spike } \\
\text { recovery. }\end{array}$ & \\
\hline $\mathrm{Ni}$ & $\begin{array}{l}\text { Natural and } \\
\text { waste waters }\end{array}$ & $\mathrm{n} / \mathrm{a}$ & $\begin{array}{l}\text { Multiwalled carbon } \\
\text { nanotubes } \\
(\mathrm{MWCN}) .\end{array}$ & FAAS & $\begin{array}{l}\text { LOD } 60 \mu \mathrm{g} \mathrm{L}^{-1} . \text { MWCN tubes } \\
\text { pretreated with potassium } \\
\text { permanganate. }\end{array}$ & 212 \\
\hline $\mathrm{Ni}$ & $\begin{array}{l}\text { Natural } \\
\text { water }\end{array}$ & Nanocomposite alumina & $\begin{array}{l}\text { Multiwalled carbon } \\
\text { nanotubes } \\
\text { (MWCN). }\end{array}$ & FAAS & $\begin{array}{l}\text { LOD } 4.1 \mu \mathrm{g} \mathrm{L}^{-1} \text {. Enrichment } \\
\text { factor 21. Adsorption at } \mathrm{pH} 9 . \\
\text { Quantitative spike recovery. }\end{array}$ & 213 \\
\hline $\mathrm{Pb}$ & $\begin{array}{l}\text { Drinking, } \\
\text { mineral and } \\
\text { tap waters }\end{array}$ & Thiosalicylic acid & Silica gel & FAAS & $\begin{array}{l}\text { LOD } 3.7 \mu \mathrm{g} \mathrm{L}^{-1} \text {. Enrichment } \\
\text { factor } 150 .\end{array}$ & 214 \\
\hline $\mathrm{Pb}$ & $\begin{array}{l}\text { Natural } \\
\text { water }\end{array}$ & $\mathrm{TiO}_{2}$ & Silica gel & GFAAS & $\begin{array}{l}\text { LOD } 9.5 \mathrm{ng} \text { L-1. Enrichment } \\
\text { factor } 50 \text {. Elution with } 1.0 \mathrm{M} \\
\mathrm{HCl} \text {. Retention facilitated in the } \\
\text { pH range } 4-7 \text {. }\end{array}$ & 215 \\
\hline $\mathrm{Pb}$ & $\begin{array}{l}\text { Surface, } \\
\text { pond, gound } \\
\text { and effluent } \\
\text { waters }\end{array}$ & Diethylammonium dithiocarbamate & $\begin{array}{l}\text { Merrifield } \\
\text { chloromethylated } \\
\text { resin. }\end{array}$ & FAAS & $\begin{array}{l}\text { LOD } 1.3 \mu \mathrm{g} \mathrm{L}^{-1} \text {. Enrichment } \\
\text { factor 27. Adsorption at } \mathrm{pH} 8-9 \text {. }\end{array}$ & 216 \\
\hline
\end{tabular}




\begin{tabular}{|c|c|c|c|c|c|c|}
\hline REE & Sea water & $\mathrm{n} / \mathrm{a}$ & $\begin{array}{l}\text { Custom prepared } \\
\text { alkyl phosphinic } \\
\text { acid resin }\end{array}$ & ICP-MS & $\begin{array}{l}\text { LOD in the range } 1.43-12.7 \mathrm{pg} \\
\mathrm{L}^{-1} \text {. Enrichment factor } 400 . \\
\text { Sample vol. } 200 \mathrm{~mL} .\end{array}$ & 217 \\
\hline $\mathrm{Sb}^{\mathrm{III}}, \mathrm{Sb}^{\mathrm{V}}$ & $\begin{array}{l}\text { Natural } \\
\text { water }\end{array}$ & Phosphoric acid & Alumina & FAAS & $\begin{array}{l}\mathrm{LOD}\left(\mu \mathrm{g} \mathrm{L^{-1 }}\right): 0.3 \text { for } \mathrm{Sb}^{\mathrm{V}} ; 1.1 \text { for } \\
\mathrm{Sb}^{\mathrm{III}} . \text { Enrichment factors, } 25 \text { for } \\
\mathrm{Sb}^{\mathrm{V}} \text { and } 50 \text { for } \mathrm{Sb}^{\mathrm{III}} . \mathrm{Sb}^{\mathrm{V}} \text { was } \\
\text { selectively eluted with } \mathrm{KOH} \text { and } \\
\mathrm{Sb}^{\mathrm{III}} \text { by } \mathrm{HCl} \text {. Quantitative spike } \\
\text { recovery. }\end{array}$ & 218 \\
\hline $\begin{array}{l}\mathrm{Se}^{\mathrm{IV}} \\
\mathrm{Se}^{\mathrm{VI}}\end{array}$ & $\begin{array}{l}\text { Natural and } \\
\text { bottled water }\end{array}$ & $\mathrm{n} / \mathrm{a}$ & $\begin{array}{l}\text { Anion-exchange } \\
\text { columns; } 2 \text { in series }\end{array}$ & ICPMS & $\begin{array}{l}\text { LOD } 1.0 \mu \mathrm{g} \mathrm{L}^{-1} \text {. Enrichment } \\
\text { factor } 20 \text {. Selective retention of } \\
\mathrm{Se}^{\mathrm{VI}} \text { on column } 1, \mathrm{Se}^{\mathrm{IV}} \text { on } 2^{\text {nd }} \text {. } \\
\text { Elution using nitric acid. } \\
\text { Ammonia as reaction gas } \\
\text { improved the detection of }{ }^{78} \mathrm{Se} \text {. }\end{array}$ & 219 \\
\hline $\mathrm{Te}$ & $\begin{array}{l}\text { Drinking } \\
\text { water }\end{array}$ & $\mathrm{n} / \mathrm{a}$ & Dowex $1 \mathrm{X} 8$ & GFAAS & $\begin{array}{l}\text { LOD } 7 \mathrm{ng} \mathrm{L}^{-1} \text {. Enrichment factor } \\
\text { 42. Elution with acetic acid. SRM } \\
\text { 1643e. }\end{array}$ & 220 \\
\hline $\mathrm{Te}^{\mathrm{IV}}$ & Seawater & $\gamma$-Mercaptopropyltrimethoxysilane. & Silica coated & ICP-MS & LOD $0.079 \mathrm{ng} \mathrm{L}^{-1} \cdot \mathrm{Te}^{\mathrm{IV}}$ & 221 \\
\hline
\end{tabular}




\begin{tabular}{|c|c|c|c|c|c|c|}
\hline & & & $\begin{array}{l}\text { magnetic } \\
\text { nanoparticles. }\end{array}$ & & $\begin{array}{l}\text { selectively adsorbed at } \mathrm{pH} 2-9 \\
\text { and eluted with } 2 \mathrm{M} \mathrm{HCl}-0.03 \mathrm{M} \\
\mathrm{K}_{2} \mathrm{Cr}_{2} \mathrm{O}_{7} . \mathrm{Te}^{\mathrm{VI}} \text { reduced with L- } \\
\text { cysteine prior to total Te } \\
\text { determination. Speciation by } \\
\text { difference. }\end{array}$ & \\
\hline $\mathrm{Tl}$ & $\begin{array}{l}\text { Natural } \\
\text { water }\end{array}$ & Dibenzo-18-crown-6 (DB18C6) & Alumina & GFAAS & $\begin{array}{l}\text { LOD } 0.05 \mu \mathrm{g} \mathrm{L}^{-1} \text {. Elution with } 2 \\
\text { M nitric acid. Quantitative spike } \\
\text { recovery. }\end{array}$ & 222 \\
\hline $\mathrm{Tl}^{\mathrm{I}}$ & Waste water & Oxine & Alumina & FAAS & $\begin{array}{l}\text { LOD } 2.5 \mu \mathrm{g} \mathrm{L}^{-1} \text {. Enrichment } \\
\text { factor } 77 . \text { In the presence of } \\
\text { EDTA only } \mathrm{Tl}^{\mathrm{I}} \text { retained. } \\
\text { Quantitative spike recovery. }\end{array}$ & 223 \\
\hline $\mathrm{U}^{\mathrm{VI}}$ & Seawater & Phenylarsonic acid. & Chitosan resin & $\begin{array}{l}\text { ICP- } \\
\text { AES }\end{array}$ & $\begin{array}{l}\text { LOD } 0.1 \mu \mathrm{g} \mathrm{L}^{-1} \text {. Enrichment } \\
\text { factor } 25 \text {. Adsorption at } \mathrm{pH} 4 \text { to } 8 \text {, } \\
\text { elution with } 1 \mathrm{M} \text { nitric acid. }\end{array}$ & 224 \\
\hline $\mathrm{V}$ & $\begin{array}{l}\text { Natural } \\
\text { water }\end{array}$ & $\mathrm{n} / \mathrm{a}$ & $\begin{array}{l}\text { Multiwalled carbon } \\
\text { nanotubes } \\
(\mathrm{MWCN}) .\end{array}$ & GFAAS & $\begin{array}{l}\text { LOD } 19 \mathrm{ng} \mathrm{L}^{-1} \text {. Enrichment factor } \\
\text { 20. Sample vol. } 1 \mathrm{~mL} \text {. Conical } \\
\text { mini-column mounted in the }\end{array}$ & 225 \\
\hline
\end{tabular}




\begin{tabular}{|l|l|l|l|l|l|}
\hline & & & & & $\begin{array}{l}\text { GFAAS autosampler arm. For } \\
\text { oxidation states } \mathrm{V}^{\mathrm{IV}} \text { was masked } \\
\text { with } 1,2 \\
\text { cyclohexanediaminetetraacetic } \\
\text { acid in order to determine } \mathrm{V}^{\mathrm{V}} .\end{array}$ \\
\hline $\mathrm{Zn}$ & $\begin{array}{l}\text { Mineral and } \\
\text { tap waters }\end{array}$ & $\mathrm{n} / \mathrm{a}$ & $\begin{array}{l}\text { Naphthalene- } \\
\text { methyltrioctyl } \\
\text { ammonium chloride }\end{array}$ & $\begin{array}{l}\text { FAAS } \\
\text { LOD } 0.6 \mu \mathrm{g} \mathrm{L}^{-1} \text { Quantitative } \\
\text { spike recovery. Retention as } \\
\text { xylenol orange complex. }\end{array}$ \\
\hline
\end{tabular}

$\mathrm{n} / \mathrm{a}$ - not applicable. 
Table 2 Cloud point extraction applications used for sample preconcentration used in the analysis of water samples..

\begin{tabular}{|c|c|c|c|c|c|c|}
\hline Analyte & Matrix & Surfactant & Chelator & Detector & Comment & Ref. \\
\hline $\mathrm{Al}^{\mathrm{III}}$ & $\begin{array}{l}\text { Natural } \\
\text { water } \\
\text { samples }\end{array}$ & Triton X-114 & $\begin{array}{l}\text { 1-Penyl-3-methyl-4- } \\
\text { benzoylpyrazol-5-one }\end{array}$ & GFAAS & LOD $90 \mathrm{ng} \mathrm{L}^{-1}$. Enrichment factor 37 & 227 \\
\hline $\mathrm{Ag}$ & $\begin{array}{l}\text { Natural } \\
\text { water }\end{array}$ & $\begin{array}{l}\text { Polyethylene } \\
\text { glycolmono-p- } \\
\text { nonylphenyleth } \\
\text { er }\end{array}$ & Not required & GFAAS & $\begin{array}{l}\text { LOD } 1.2 \mathrm{ng} \mathrm{L}^{-1} \text {. Enrichment factor } \\
60 .\end{array}$ & 228 \\
\hline $\mathrm{Be}$ & $\begin{array}{l}\text { Natural } \\
\text { water }\end{array}$ & $\begin{array}{l}\text { Cetyl- } \\
\text { pyridinium - } \\
\text { Triton X-114 }\end{array}$ & 1,8-Dihydroxyanthrone. & ICP-AES & LOD $1.0 \mathrm{ng} \mathrm{L}^{-1}$. Buffered at $\mathrm{pH} 9.5$. & 229 \\
\hline $\mathrm{Cd}, \mathrm{Pb}$ & $\begin{array}{l}\text { Drinking } \\
\text { water }\end{array}$ & Triton $\mathrm{X}-114$ & $\begin{array}{l}\text { 2-(2-Thiazolylazo)-p- } \\
\text { cresol }\end{array}$ & FAAS & $\begin{array}{l}\text { LOD }\left(\mu \mathrm{g} \mathrm{L}^{-1}\right): 0.08 \text { for } \mathrm{Cd} ; 1.05 \mathrm{~Pb} \text {. } \\
\text { Quantitative spike recovery. }\end{array}$ & 230 \\
\hline $\begin{array}{l}\mathrm{Cd}, \mathrm{Co}, \\
\mathrm{Cr}, \mathrm{Mn}\end{array}$ & $\begin{array}{l}\text { Saline } \\
\text { water }\end{array}$ & Triton $\mathrm{X}-114$ & Dithizonate complexes & ICP-AES & $\begin{array}{l}\text { LODs }\left(\mu \mathrm{g}^{-1}\right): 0.09 \text { for } \mathrm{Cd} ; 0.2 \text { for } \mathrm{Co} \text {; } \\
1.2 \text { for } \mathrm{Cr} ; 0.73 \text { for Mn. Enrichment } \\
\text { factor } 9 \text { - } 21 . \text { Quantitative spike } \\
\text { recovery. }\end{array}$ & 231 \\
\hline $\begin{array}{l}\mathrm{Cd}, \mathrm{Co}, \\
\mathrm{Cr}, \mathrm{Cu}\end{array}$ & $\begin{array}{l}\text { Tap, well, } \\
\text { sea and }\end{array}$ & Triton X-114 & $\begin{array}{l}\text { 1-(2-Thenoyl)-3,3,3- } \\
\text { trifluoraceton }\end{array}$ & ICP-AES & LOD in range $0.1-2.2 \mu \mathrm{g} \mathrm{l}^{-1}$. & 232 \\
\hline
\end{tabular}




\begin{tabular}{|c|c|c|c|c|c|c|}
\hline $\mathrm{Fe}, \mathrm{Mn}$ & $\begin{array}{l}\text { mineral } \\
\text { waters }\end{array}$ & & & & $\begin{array}{l}\text { Adsorption at } \mathrm{pH} 6 \text {. Elution with } \\
\text { propanol }-0.5 \mathrm{M} \text { nitric acid }(75: 25 \\
\mathrm{v} / \mathrm{v}) \text {. }\end{array}$ & \\
\hline $\begin{array}{l}\mathrm{Co}, \mathrm{Cu}, \\
\mathrm{Ni}\end{array}$ & $\begin{array}{l}\text { Natural } \\
\text { and waste } \\
\text { waters }\end{array}$ & Triton X-114 & $\begin{array}{l}\text { Methyl-2-pyridylketone } \\
\text { oxime }\end{array}$ & FAAS & $\begin{array}{l}\text { LODs }\left(\mu \mathrm{g}^{-1}\right): 2.1 \text { for } \mathrm{Co} ; 1.6 \text { for } \mathrm{Cu} \\
1.9 \text { for Ni. Enrichment factors } 58- \\
67 .\end{array}$ & 233 \\
\hline $\mathrm{Cr}^{\mathrm{III}}$ & $\begin{array}{l}\text { Natural } \\
\text { water } \\
\text { samples }\end{array}$ & NR & $\begin{array}{l}\text { 1-Penyl-3-methyl-4- } \\
\text { benzoylpyrazol-5-one }\end{array}$ & GFAAS & $\begin{array}{l}\text { LOD } 21 \mathrm{n} \mathrm{L}^{-1} \text {. Enrichment factor } 42 . \\
\text { Selective extraction of } \mathrm{Cr}^{\mathrm{III}} \text { with } \\
\text { chelator. Total } \mathrm{Cr} \text { determination after } \\
\text { reduction of } \mathrm{Cr}^{\mathrm{III}} \text { using ascorbic acid. }\end{array}$ & 234 \\
\hline $\mathrm{Cr}^{\mathrm{VI}}$ & $\begin{array}{l}\text { River } \\
\text { water }\end{array}$ & Triton X-114 & $\begin{array}{l}\text { Ammonium } \\
\text { pyrrolidinedithiocarbamate }\end{array}$ & GFAAS & $\begin{array}{l}\text { LOD } 2.5 \mathrm{ng} \mathrm{L}^{-1} \text {. Enrichment factor } \\
\text { 30. } \mathrm{Cr}^{\mathrm{VI}} \text { was selectively extracted at } \\
\mathrm{pH} 3.0 \text { and total } \mathrm{Cr} \text { at } \mathrm{pH} 5.0 \text { without } \\
\text { an oxidation process. }\end{array}$ & 235 \\
\hline $\mathrm{Cu}$ & $\begin{array}{l}\text { Natural } \\
\text { water }\end{array}$ & Triton $\mathrm{X}-114$ & $\begin{array}{l}\text { 6-(2-Naphthyl)-2,3- } \\
\text { dihydro-as-triazine-3- } \\
\text { thione }\end{array}$ & FAAS & $\begin{array}{l}\text { LOD } 0.22 \mu \mathrm{g} \mathrm{L}^{-1} \text {. Enrichment factor } \\
\text { 22.4. Buffered at } \mathrm{pH} 8.5 \text { using borate } \\
\text { buffer, at } 40^{\circ} \mathrm{C} \text {. }\end{array}$ & 236 \\
\hline $\mathrm{Cu}$ & $\begin{array}{l}\text { Sea and } \\
\text { river }\end{array}$ & Triton X-114 & 1,5-Diphenyl-bezoin. & FAAS & $\begin{array}{l}\text { LOD } 0.04 \mu \mathrm{g} \mathrm{L}^{-1} \text {. Enrichment factor } \\
88 .\end{array}$ & 237 \\
\hline
\end{tabular}




\begin{tabular}{|c|c|c|c|c|c|c|}
\hline & waters. & & & & & \\
\hline $\mathrm{Ni}$ & $\begin{array}{l}\text { Natural } \\
\text { water }\end{array}$ & Triton X-114 & $\begin{array}{l}\text { N-quino[8,7-b]azin-5-yl- } \\
\text { 2,3,5,6,8,9,11,12- } \\
\text { octahydrobenzo[b][1,4,7,1 } \\
\text { 0,13]pentaoxacyclopentad } \\
\text { ecin-15-yl-methanimine }\end{array}$ & FAAS & $\begin{array}{l}\text { LOD } 42 \mathrm{ng} \mathrm{L}^{-1} \text {. Enrichment factor } 50 . \\
\text { Quantitative spike recovery. }\end{array}$ & 238 \\
\hline $\mathrm{Pb}$ & $\begin{array}{l}\text { Natural } \\
\text { water }\end{array}$ & Triton X-114 & $\begin{array}{l}\text { 1-Phenyl-3-methyl-4- } \\
\text { benzoyl-5-pyrazolone }\end{array}$ & FAAS & $\begin{array}{l}\text { LOD } 1.49 \mu \mathrm{g} \text { L-1. Enrichment factor } \\
110 .\end{array}$ & 239 \\
\hline $\mathrm{Pd}$ & $\begin{array}{l}\text { Natural } \\
\text { water }\end{array}$ & Triton $\mathrm{X}-114$ & $\begin{array}{l}\text { 4-(2-Naphthalenyl)thiozol- } \\
\text { 2-yl azo chromotropic acid }\end{array}$ & FAAS & $\begin{array}{l}\text { LOD } 67 \mathrm{ng} \text { L-1. Enrichment factor } \\
\text { 50. Quantitative spike recvery. }\end{array}$ & 240 \\
\hline $\mathrm{Pb}$ & $\begin{array}{l}\text { Natural } \\
\text { water }\end{array}$ & Triton X-114 & Diethyldithiophosphate & GFAAS & $\begin{array}{l}\text { LOD } 16 \mathrm{ng} \mathrm{L}^{-1} \text {. Enrichment factor } 22 . \\
\text { Online formation of analyte surfactant } \\
\text { micelles, trapping on silica gel } \\
\text { microcolumn. Methanol elution. } \\
\text { Quantitative spike recovery. }\end{array}$ & 241 \\
\hline $\begin{array}{l}\mathrm{Sb}^{\mathrm{III}}, \\
\mathrm{Sb}^{\mathrm{V}}, \mathrm{Se}^{\mathrm{IV}} \\
\text { and } \mathrm{Se}^{\mathrm{VI}}\end{array}$ & $\begin{array}{l}\text { Natural } \\
\text { water }\end{array}$ & Triton X-114 & Diethyldithioarbamate & $\begin{array}{l}\text { ETV- } \\
\text { ICPMS }\end{array}$ & $\begin{array}{l}\text { LODs }\left(\mu \mathrm{g}^{-1}\right): 0.03 \text { for } \mathrm{Sb} ; 0.05 \text { for } \\
\text { Se. Speciation of oxidation states by } \\
\text { selective complex formation of } \mathrm{Sb}^{\mathrm{III}} \\
\text { and } \mathrm{Se}^{\mathrm{IV}} \text { with DDTC. Total } \mathrm{Sb} \text { and } \mathrm{Se}\end{array}$ & 242 \\
\hline
\end{tabular}




\begin{tabular}{|c|c|c|c|c|c|c|}
\hline & & & & & $\begin{array}{l}\text { after reduction with L-cysteine, } \\
\text { speciation by difference. }\end{array}$ & \\
\hline $\mathrm{Tl}$ & $\begin{array}{l}\text { River and } \\
\text { sea waters }\end{array}$ & $\begin{array}{l}\text { Sodium dodecyl } \\
\text { sulfate (SDS), } \\
\text { Triton X-114 }\end{array}$ & $\begin{array}{l}\text { Diethylenetriaminepentaac } \\
\text { etic acid }\end{array}$ & ICP-MS & $\begin{array}{l}\text { LOD } 20 \mathrm{pg} \mathrm{L}^{-1} \text {. Enrichment factor } \\
\text { 125. Extraction of } \mathrm{Tl}^{\mathrm{III}} \text { in } \mathrm{HCl} \\
\text { medium. } \mathrm{Tl}^{\mathrm{I}} \text { extraction after bromine } \\
\text { oxidation. Trace elements in water } \\
\text { NIST SRM } 1643 \mathrm{c} \text { and open ocean } \\
\text { seawater NASS-4 and NASS-5. }\end{array}$ & 243 \\
\hline
\end{tabular}





\section{$3 \quad$ Analysis of soils, plants and related materials}

Numerous studies involving analysis of soils and plants have been published in the past year. Whilst providing valuable insight into environmental pollution and processes, especially plant uptake of trace elements, many involve the use of wellestablished analytical techniques such as ICP-AES, ICP-MS and XRF. These studies are not considered further here. This section instead focuses on progress in analytical methods and techniques for the analysis of soils, plants and related materials since the last Update ${ }^{1}$.

\subsection{Sample preparation}

\subsubsection{Sample dissolution and extraction}

During digestion of highly siliceous samples, $\mathrm{Si}$ is commonly removed by treatment with $\mathrm{HF}$ and volatilisation as $\mathrm{SiF}_{4}$. However, this has proved problematic in samples that contain high levels of $\mathrm{Na}$ or $\mathrm{K}$ because of the formation of insoluble fluorosilicates. A new method for the removal of Si from soil digest, which exploits this chemistry to advantage, has been proposed ${ }^{244}$. Silicon and $\mathrm{Na}$ were simultaneously co-precipitated as $\mathrm{Na}_{2} \mathrm{SiF}_{6}$ by addition of $\mathrm{NaCl}$ to the sample digests. Trace elements were then back-extracted from the precipitate in a $4+1$ mixture of $\mathrm{MeOH}$ and $\mathrm{HNO}_{3}$ and determined by ICP-MS. The method was able to remove over 90\% of the Si present in NIST SRM 2711 Montana soil and NIST SRM 2704 Buffalo River sediment and provided accurate results, even for elements such as $\mathrm{As}, \mathrm{Hg}$ and Se that often suffer losses in conventional digestion procedures involving heatassisted $\mathrm{SiF}_{4}$ volatilisation.

Scancar et al. ${ }^{245}$ optimised a method for the challenging selective extraction of exchangeable $\mathrm{Cr}^{V I}$ from soil by mechanical shaking with $\mathrm{KH}_{2} \mathrm{PO}_{4}-\mathrm{K}_{2} \mathrm{HPO}_{4}$ buffer. The analyte was separated by anion exchange, fast protein liquid chromatography and quantified, off-line, by ETAAS. A detection limit of $15 \mathrm{ng} \mathrm{g}^{-1}$ was achieved with a soil to extractant ratio of 1 : 10 , a $16 \mathrm{~h}$ shaking period and $1.0 \mathrm{~mol} \mathrm{~L}^{-1}$ extractant concentration. The accuracy was assessed by soil spike-and-recovery experiments and by analysis of BCR CRM $544 \mathrm{Cr}^{\mathrm{VI}}$ in lyophilised solution. A more rapid method of extraction for the same analyte, but with poorer LOD (70 $\left.\mathrm{ng} \mathrm{g}^{-1}\right)$ was reported by Mandiwana $^{246}$. This procedure involved boiling $0.25 \mathrm{~g}$ soil in $25 \mathrm{~mL}$ of $0.01 \mathrm{~mol} \mathrm{~L}^{-1}$ 
$\mathrm{Na}_{3} \mathrm{PO}_{4}$ on a hotplate for $5 \mathrm{~min}$, followed by filtration of the extract and quantification of the analyte by ETAAS. Results were comparable with those obtained by a $\mathrm{Na}_{2} \mathrm{CO}_{3}$ extraction method previously published by the same author.

Extraction of As has been of interest. Yuan et al. ${ }^{247}$ used soils spiked with $\mathrm{As}^{\mathrm{III}}, \mathrm{As}^{\mathrm{V}}$, DMA and MMA to compare conventional shaking with ultrasound and microwave-assisted extraction. Their preferred method was microwave-assisted extraction in $0.5 \mathrm{~mol} \mathrm{~L}^{-1} \mathrm{Na}_{3} \mathrm{PO}_{4}$ buffer. A procedure yielding significantly improved extraction of As from plants has been reported ${ }^{248}$. By using water-methanol solution $(1+1)$, the authors were able to isolate organoarsenic species inaccessible to $0.1 \mathrm{~mol}$ $\mathrm{L}^{-1} \mathrm{HCl}$. Inorganic forms of As were readily extractable in $\mathrm{HCl}$. The reagents were therefore combined in a two-step sequential extraction. The authors used XANES to check for $\mathrm{As}^{\mathrm{III}}$ and $\mathrm{As}^{\mathrm{V}}$ inter-conversion during sample handling. None was found.

Guidelines for the use of sequential chemical extraction are provided in a critical review (547 refs) by Bacon and Davidson ${ }^{14}$. Recommendations include greater use of CRMs, mass-balance experiments and standard extraction procedures, for example that recommended by BCR. Users were cautioned against interpretation of sequential extraction results as indicative of phase-associations between analytes and specific soil minerals. Another review (303 refs), by Rao et al. ${ }^{15}$, focussed on procedures for both single and sequential extraction of soils and related materials.

The $B C R$ sequential extraction has been applied, with ETAAS, to obtain data on the fractionation of $\mathrm{V}$ in soil and sewage sludge reference materials ${ }^{249}$. The element was found almost exclusively in the residual fraction in soils, but partly in the reducible $(25 \%)$ and oxidisable $(\sim 10 \%)$ fractions in sludges. Kubova et al. ${ }^{250}$ applied sequential extraction to study the uptake of metals by plants growing in highly acidic soils ( $\mathrm{pH} 3.0$ - 3.5, measured in a suspension containing $1 \mathrm{~g}$ soil per $2.5 \mathrm{~mL} \mathrm{H}_{2} \mathrm{O}$ ) and found correlations between metals extractable in BCR Step $1\left(0.11 \mathrm{~mol} \mathrm{~L}^{-1}\right.$ acetic acid) and concentrations in plant tissue. Improving the rapidity of sequential extraction by ultrasonic or microwave assistance, and by carrying out the steps in parallel rather than sequentially, was explored by Arain et al. ${ }^{251}$. Whilst the authors were able to optimise all of the proposed procedures to obtain analyte recoveries similar to that of the standard BCR protocol for the sediments studied, the transferability of the devised methods to other sample types was not assessed.

An interesting approach for estimating metal mobility in soil was described by Beeston et $a l .^{252}$. They connected a fluidised bed column, the geometry of which 
prevents soil compaction that had proved a problem in previous studies, directly to the inlet of an ICP-MS instrument. A quaternary HPLC pump was used to deliver a linear gradient from $0.05 \mathrm{~mol} \mathrm{~L}^{-1}$ ammonium sulfate to $0.11 \mathrm{~mol} \mathrm{~L}^{-1}$ acetic acid to the soil column. The extractograms obtained were reproducible and proved useful in identifying possible associations between analytes.

\subsubsection{Pre-concentration procedures}

Cloud point extraction, which has proved popular for the analysis of waters, is now being applied to soil and plant extracts (Table 1). Many authors have reported new sorbent systems for the solid phase extraction and pre-concentration of metals in extracts of soils and related substrates. These are summarised in Table 2, which complements the review (174 refs) by Turker ${ }^{253}$. Pre-concentration by precipitation is also of interest (Table 3). Whilst almost all pre-concentration studies include the analysis of CRMs to assess the accuracy of the method proposed, it is noticeable that some feature CRMs of rather dissimilar nature to the intended sample type(s); closer matrix matching would be desirable.

\subsection{Speciation}

Three areas are of particular interest: studies involving chromatography coupled directly to ICP-MS; the use of ICP-MS together with molecular mass spectrometry; and applications involving, generally, multiple X-ray based techniques. The first two topics are considered here and the last in Section 3.3.6.

Forsgard et $a l .{ }^{254}$ used a nitrogen-free modifier in the mobile phase and cool plasma conditions to overcome polyatomic ion interferences in a study of $\mathrm{Al}$ speciation in soil solution. Parallel application of LC-ICP-MS and LC-ES-MS/MS allowed identification of the aluminium-chelated siderophores, Al-desferrichrom and Al-desferricrocin.

In studies of As speciation, monomethylarsonous and monomethylthioarsonic acid were first discovered in terrestrial food plants - freeze dried carrot - by Yathavakilla et al. ${ }^{255}$ using anion exchange chromatography with ICP-MS and ES-MS detection. Bluemlein et al. ${ }^{256}$ exposed specimens of Thunbergia alata to arsenate and then analysed formic acid extracts of the plants' roots by reversed-phase HPLC-ESMS/ICP-MS. Between 55 and $64 \%$ of the As was found in the form of As ${ }^{\text {III }}$ 
phytochelatins. This result was supported by XANES, where 53\% of the arsenic was found to be in a chemically similar environment to that of an As ${ }^{\text {III }}$ (glutathione) 3 standard, and by EXAFS, which indicated the presence of $\mathrm{As}^{\mathrm{III}}-\mathrm{S}$ bonding. This finding is consistent with studies ${ }^{475}$ that also identified high proportions of arsenic(III)-sulfur compounds in the tissues of plants originally exposed to $\mathrm{As}^{\mathrm{V}}$.

Chen et al. ${ }^{476}$ characterised Cd-phytochelatins in Cd-stressed Brassica chinensis by means of SEC-ICP-MS and ES-MS/MS. The metallopeptides Cd-PC3 and Cd-PC4 were detected, together with Cd-free PCs and desGlu-PC3. Meanwhile, Sadi et $a l .^{257}$ developed a method for the quantification of Cd-PC2, Cd-PC3 and CdPC4 by reversed-phase HPLC-ICP-MS. Slight modification of the interface was necessary to accommodate a high methanol concentration in the HPLC mobile phase. Detection limits were between 49 and $92 \mathrm{ng} \mathrm{L}{ }^{-1}$. The method was used to compare Cd-PC complexes in wild-type Arabidopsis thaliana and in a transgenic variant. This topic is of interest since genetic modification may play a key role in designing plants with enhanced phytoremediation capabilities.

Liquid chromatography has been used with DRC-ICP-MS to separate and quantify $\mathrm{Cr}^{I I I}$ and $\mathrm{Cr}^{V I}$ species. Kuo et al. ${ }^{258}$, who also determined $\mathrm{V}^{\mathrm{IV}}$ and $\mathrm{V}^{\mathrm{V}}$ under the same conditions, obtained detection limits of $0.05 \mathrm{ng} \mathrm{mL}^{-1}$ for $\mathrm{Cr}$ and $0.06 \mathrm{ng} \mathrm{mL}^{-}$ ${ }^{1}$ for $\mathrm{V}$. The method was validated by analysis of NIST SRMs, and applied to soil and leaves. Wolf et al. ${ }^{129}$ reported similar LODs of $0.09 \mu \mathrm{g} \mathrm{L}^{-1}$ for $\mathrm{Cr}^{\mathrm{III}}$ and $0.06 \mu \mathrm{g} \mathrm{L}^{-1}$ for $\mathrm{Cr}^{\mathrm{VI}}$

Polec-Pawlak et al. ${ }^{259}$ used SEC-ES-MS and SEC-ICP-MS in a study of lead speciation in Arabidopsis thaliana. The authors were particularly interested in bioligands other than the well-known phytochelatins and glutathiones, and were successful in identifying a potential $\mathrm{Pb}$-pectin interaction. Chelate-enhanced phytoextraction is an important approach for remediation of metal-contaminated soil but a better understanding is required of how the addition of compounds such as EDTA alters metal speciation and, hence, metal availability to plants. To investigate this, Chen et al. ${ }^{477}$ first applied ES-MS to confirm the existence of aminocarboxylic lead species and then used IC-ICP-MS to identify and quantify them in soil solution from a phytoremediation site. Both $\{\mathrm{Pb}(\mathrm{HEDA})\}^{-}$and $\{\mathrm{Pb}(\mathrm{EDTA})\}^{2-}$ were detected at concentrations of around $1.2 \mu \mathrm{g} \mathrm{L}^{-1}$. 
In studies of the speciation of other elements, reversed phase HPLC followed by simultaneous detection by ES-MS and ICP-MS has been applied in the speciation of cysteine and glutathione complexes of $\mathrm{Hg}$ and methylmercury in plants ${ }^{260}$. Methods for on-line separation and detection by anion exchange chromatographyICP-MS of $\mathrm{I}^{-}$and $\mathrm{IO}_{3}{ }^{-}$in soil solution ${ }^{261}$; of $\mathrm{Sb}^{\mathrm{III}}$ and $\mathrm{Sb}^{\mathrm{V}}$ in sediments ${ }^{262}$; of $\mathrm{Se}^{\mathrm{IV}}$ and $\mathrm{Se}^{\mathrm{VI}}$ in water and soil ${ }^{132}$; and of $\mathrm{MoO}_{4}{ }^{2-}, \mathrm{PO}_{4}{ }^{3-}$ and $\mathrm{WO}_{4}{ }^{2-}$ in groundwater and soil ${ }^{263}$ have been reported.

\subsection{Instrumental analysis}

\subsubsection{Atomic absorption spectrometry}

Han et al. ${ }^{264}$ developed an on-line sample digestion manifold based on electromagnetic induction heating that could be coupled directly to FAAS. After optimisation of the operating conditions (temperature $98{ }^{\circ} \mathrm{C}$; column length $50 \mathrm{~cm}$; acid composition $3.5 \mathrm{~mol} \mathrm{~L}^{-1} \mathrm{HNO}_{3}+1.0 \mathrm{~mol} \mathrm{~L}^{-1} \mathrm{HClO}_{4}$; flow rate $3.6 \mathrm{~mL} \mathrm{~min}^{-1}$ ) the apparatus generated results similar to those from off-line digestion and in agreement with certificate values for reference teas GBW 07605 and 08505. A fully-automated, on-line, flow-injection system for use in the determination of Sb by ETAAS has been described $^{265}$. Analysis and pre-concentration proceed in parallel: while one sample undergoes atomisation, the $\mathrm{Sb}$ in the next sample is collected on a micro-column ready for injection.

Atom trapping as a means to increase the sensitivity of FAAS measurement appears to be experiencing a resurgence of interest. Matusiewicz and Krawczyk ${ }^{140}$ developed a hyphenated HG-IAT-FAAS system for use in the determination of Sb. The detection limit for a $2 \mathrm{~mL}$ sample and $120 \mathrm{~s}$ trapping time was $0.2 \mathrm{ng} \mathrm{mL}{ }^{-1}$ with precision of $8.0 \%$ RSD $(n=6)$. Antimony speciation was also possible by alteration of the sample pre-treatment procedure, with the addition or absence of L-cysteine. Ertas et $a .^{266}$ trapped lead hydride, generated on-line under optimised conditions, on the inner walls of a slotted quartz T-tube, under fuel-lean conditions, before introducing a $50 \mu \mathrm{l}$ volume of MIBK to generate a pulse of lead atoms for detection. With a $7.8 \mathrm{~mL}$ sample and trapping duration of $90 \mathrm{~s}$, LODs as low as $0.028 \mu \mathrm{g} \mathrm{L}^{-1}$ could be achieved 
Concerns over difficulties in analysing small samples by conventional nebulisation FAAS prompted Kekedy-Nagy et $a .^{267}$ to investigate the use of platinum wire atomisation in a low temperature, methane-air, flame. Sample volumes as small as $3 \mu \mathrm{l}$ were used. The method was applied in the determination of $\mathrm{Zn}$ in acid digests of lichen and leaves, and directly on grape sap.

There are still developments in chemical modifiers for ETAAS, but mainly for less-common analytes. Husakova et al. ${ }^{268}$ found a mixture of palladium, citric acid and lithium suitable for use in the determination of $\mathrm{Tl}$ in aqua regia digests of soils and sediments, whilst Lopez-Garcia et $a .^{269}$ recommended sodium tungstate as a permanent modifier for measuring In in soils by slurry sampling.

Nomura et al. ${ }^{270}$ used solid sampling ETAAS in a study of synthetic calibration standards for techniques such as LIBS and LA-ICP-MS. The homogeneity of filter papers that had been spiked with standard solutions of $\mathrm{Cu}$ and $\mathrm{Zn}$, dried, and then ground under cryogenic conditions, was assessed. Linear calibration curves were obtained, along with acceptable results for a range of plantderived CRMs.

Whilst the vast majority of studies over the past year have involved, as would be expected, FAAS and ETAAS, other forms of atomic absorption spectrometry have also undergone developments with a view to their application in the analysis of soil and plants. Cankur and Ataman ${ }^{271}$ used an unheated quartz T-tube as an absorption cell for the measurement of $\mathrm{Cd}$. The analyte, as its hydride, was first pre-concentrated on a tungsten coil situated in the inlet arm of the T-tube, then rapidly re-atomised at $1000{ }^{\circ} \mathrm{C}$ into the optical path of the spectrometer. An enrichment factor of 31 was achieved, and the LOD was $4.0 \mathrm{ng} \mathrm{L}^{-1}$ for a $4.2 \mathrm{~mL}$ sample. The method gave satisfactory agreement with certified values for Cd in NIST SRM 1566b Oyster tissue, NIST SRM 1573a Tomato leaves and BCR CRM 403 Trace elements in sea water. Wu et al. ${ }^{272}$ exploited the relative stabilities of metal-DDTC complexes to create a new method for interference-free measurement of $\mathrm{Ag}$ in soil and sediment by thermospray flame furnace AAS. Copper-DDTC was generated and a cloud point extraction performed. A sample, or Ag standard solution, was then introduced. The $\mathrm{Ag}$ therein is able to displace the $\mathrm{Cu}$ from its complex but potential interferents such as alkali, alkali-earth, and transition metals cannot because they do not form stable chelates with DDTC. A second cloud point extraction yielded a surfactant-rich 
solution in which Ag had been successfully pre-concentrated, free from potential matrix interferents, ready for analysis. The method LOD was $0.2 \mu \mathrm{g} \mathrm{L} \mathrm{L}^{-1}$, the precision was $3.1 \% \mathrm{RSD}$ at $5 \mu \mathrm{g} \mathrm{L}^{-1}(\mathrm{n}=7)$, the enrichment factor, defined as the sensitivity enhancement relative to use of a single cloud point extraction, was 21 , and results obtained for CRMs were statistically similar to certified values.

\subsubsection{Atomic emission spectrometry}

Slurry sample introduction remains a topic of active research. Lkiewicz et $a l .{ }^{273}$ showed that similar performance could be obtained with ICP-AES for the determination of $\mathrm{Ca}, \mathrm{Mg}$ and $\mathrm{Pb}$ in plant roots by slurry sampling and by analysis of sample digests. The measurement of Pb by slurry-sampling and HG-ICP-AES with an axial-view spectrometer has recently been reported for the first time ${ }^{274}$. Full factorial analysis was used to optimise conditions for on-line plumbane generation, from both an aqueous standard and for a slurry of NIST SRM 2702 Marine sediment $(20 \mathrm{mg}$ solid in $50 \mathrm{~mL}$ ). Maximum signal intensity and plasma stability were obtained with $10 \%(\mathrm{~m} / \mathrm{v})\left(\mathrm{NH}_{4}\right)_{2} \mathrm{~S}_{2} \mathrm{O}_{8}$ in $2 \%(\mathrm{v} / \mathrm{v})$ aqua regia, $0.5 \%(\mathrm{~m} / \mathrm{v})$ tartaric acid and $2.5 \%$ $(m / v) \mathrm{NaBH}_{4}$. Under these conditions Sn could also be quantified and the reported detection limits were $5.0 \mu \mathrm{g} \mathrm{g}^{-1}$ for $\mathrm{Pb}$ and $1.0 \mu \mathrm{g} \mathrm{g}^{-1} \mathrm{Sn}$.

Masson et al. ${ }^{275}$ employed electrothermal vaporisation-ICP-AES in the direct determination of $\mathrm{Cd}$ and $\mathrm{Si}$ in a variety of plant tissues, both CRMs and environmental samples. Calibration was achieved by means of aqueous standard solutions deposited onto a cellulose support.

In laser ablation ICP-AES, Hubova et al. ${ }^{276}$ used sol-gels as a binder in the preparation of soil samples, and also of calibration pellets containing both the analytes $(\mathrm{Cr}, \mathrm{Cu}, \mathrm{Ni}, \mathrm{Pb}$ and $\mathrm{Zn})$ and a $\mathrm{Sc}$ internal standard. The precision of the method was $<$ $7 \%$ RSD. However, bias of between 6 and 15\% was found when results were compared with those from XRF and with analysis of a $\mathrm{HF}-\mathrm{HClO}_{4}$ digest of a soil CRM by pneumatic nebulisation ICP-AES.

Donati et al. ${ }^{277}$ reported progress towards a field-portable tungsten-coil atomic emission spectrometer. All fourteen lanthanides could be determined when just $25 \mu 1$ of solution was atomised from the coil using a seven-step heating programme. Limits of detection ranged from $0.8 \mu \mathrm{g} \mathrm{L}^{-1}$ (Yb) to $600 \mu \mathrm{g} \mathrm{L}^{-1}$ (Nd and $\mathrm{Pr}$ ). It was suggested these could be improved, roughly three-fold, by monitoring several spectral lines for 
the same element and summing the response. A precision of $<7 \% \operatorname{RSD}(n=10)$ was obtained for all analytes except $\operatorname{Er}(8.4 \%)$ and La (8.2\%). Accuracy was assessed by analysis of a digest of NIST SRM 2711 Montana soil. Interestingly, the authors propose that the sample digestion, which involved treatment of $1 \mathrm{~g}$ of soil with $1 \mathrm{~mL}$ $\mathrm{HNO}_{3}$ and heating to $100{ }^{\circ} \mathrm{C}$ for $1 \mathrm{~h}$, could also be carried out in the field.

Microwave-induced plasma AES has been used as an element-specific detector in a gas chromatographic method for the determination of the anti-knock agents cyclopentadienylmanganese tricarbonyl and (methylcyclopentadienyl)manganese tricarbonyl ${ }^{278}$. Extraction and instrumental parameters were optimised and LODs of $<$ $0.6 \mathrm{pg} \mathrm{g}^{-1} \mathrm{Mn}$ in soil and precisions of $<7 \%$ RSD obtained.

\subsubsection{Atomic fluorescence spectrometry}

Recent progress in flow injection hydride generation AFS, with particular emphasis on miniaturised, on-line, sample pre-treatment methods, has been reviewed (37 refs) by Chen et al. ${ }^{478}$. As is the case for AES, there is current interest in development of field-portable AFS. Zhu et al. ${ }^{279}$ described a low-cost, miniaturised, AFS system which employs a dielectric barrier discharge to create a micro-plasma suitable for atomisation of hydride-forming elements. Arsenic was used to assess the performance of the instrument, yielding a LOD of $0.04 \mu \mathrm{g} \mathrm{L}^{-1}$ and RSD of $1.1 \%$ at 10 $\mu \mathrm{g} \mathrm{L}^{-1}(\mathrm{n}=11)$. Results for reference materials GBW(E) 080390 Water and NIST SRM 1571 Orchard leaves were acceptable and recoveries with respect to data generated by HPLC-ICP-MS were close to $100 \%$. It was claimed that with careful $\mathrm{pH}$ control the method could be used to distinguish between $\mathrm{As}^{\mathrm{III}}$ and $\mathrm{As}^{\mathrm{V}}$ in water samples. Reyes et $a l .{ }^{280}$ also reported a method for the non-chromatographic speciation of As in plant tissue by HG-AFS, involving the use of several different experimental conditions and a set of proportional equations to calculate species concentrations. In contrast, Yuan et $a .^{247}$ opted for a chromatographic approach (HPLC-HG-AFS).

\subsubsection{Mass spectrometry}

\subsubsection{Inductively-coupled plasma mass spectrometry}


Sample introduction remains an active research area. In laser ablation, Fernandez et $a l .^{281}$ described the preparation and use of isotopically enriched solid "spikes" in the quantification of $\mathrm{Cu}, \mathrm{Pb}, \mathrm{Sn}$ and $\mathrm{Zn}$ by isotope dilution $f s$ LA-ICP-MS. Reproducibilities of $<10 \%$ RSD $(n=8)$ were achieved by the proposed method and results obtained for soil and sediment reference materials agreed with certified values. An optimised method for LA-ICP-MS analysis of compost has been reported ${ }^{282}$. Detailed investigation of the causes of imprecision in sample pellet preparation indicated that particle size and grinding time were, not surprisingly, key factors. Quantification was possible for $\mathrm{Cd}, \mathrm{Co}, \mathrm{Cr}, \mathrm{Cu}, \mathrm{Hg}, \mathrm{Mn}, \mathrm{Ni}, \mathrm{Pb}$ and $\mathrm{Zn}$ with either matrix-matched standards or by use of standard addition with aqueous calibrants. Cizdziel et $a l .{ }^{283}$ applied LA-ICP-MS to archived planchets previously analysed for $\mathrm{Pu}$ isotopes by alpha spectrometry. Results agreed well with earlier radiometric measurements and isotope ratios were consistent with data obtained by SF-ICP-MS following total digestion of soils and dust samples. A LA-ICP-MS method for Cd speciation in plants has been described ${ }^{284}$. Ultrasound was used to isolate proteins from Spinacia oleracea (spinach). These were then separated by PAGE, the gel was blotted, and the Cd content of the bands was assessed.

Xia et al. ${ }^{166}$ described a new method of hollow-fibre micro-extraction, involving trapping of $\mathrm{Bi}, \mathrm{Cd}, \mathrm{Cu}, \mathrm{Hg}, \mathrm{Pb}, \mathrm{Pd}$ and $\mathrm{Zn}$ as their DDTC chelates, which was suitable for use with ETV-ICP-MS. Chelate formation allowed a lower vaporisation temperature $\left(1300^{\circ} \mathrm{C}\right)$ to be used and enhanced the sensitivity. Detection limits were in the range $1.6-12 \mathrm{pg} \mathrm{mL}^{-1}$, except for $\mathrm{Zn}\left(29 \mathrm{pg} \mathrm{mL}^{-1}\right)$, and precision was generally $<10 \% \mathrm{RSD}$ at $0.5 \mathrm{ng} \mathrm{mL}^{-1}(\mathrm{n}=7)$. The method was validated by analysis of the IGGE CRM GBW 08501 Peach leaves and applied to water and human serum samples.

Hydride generation-GC-ICP-MS, a useful technique for studying non-volatile methylated organometal(loid) species in the environment, suffers from the limitation that different analyte species require different $\mathrm{pH}$ conditions for efficient conversion to their volatile hydrides. This problem has been overcome by Diaz-Bone and Hitzke $^{285}$. They constructed a semi-automated derivatisation unit that allowed a $\mathrm{pH}$ gradient to be applied to the sample (from $\mathrm{pH} 7$ to $\mathrm{pH}$ 1, over a period of $8 \mathrm{~min}$ ) along with a continuous supply of $\mathrm{NaBH}_{4}$. The unit was coupled, via cryotraps, to a GCICP-MS instrument. The method was assessed by spiking compost and sediment with 
various methylated arsenic, tin and antimony species. Satisfactory recoveries of $96-$ $102 \%$ were obtained.

The development of multi-collector instruments has enhanced the scope for simultaneous measurement of isotopes by ICP-MS. However, because these systems are expensive, research on isotope ratio measurement by quadrupole instruments has continued. Garcia-Ruiz ${ }^{286}$ and co-workers developed an ion chromatographic method for on-line separation of $\mathrm{Rb}$ and $\mathrm{Sr}$ before introduction into a quadrupole ICP-MS, which they later adapted and coupled to MC-ICP-MS ${ }^{287}$. The injection of large volumes $(3 \mathrm{ml})$ and a mobile phase containing $900 \mathrm{mM}$ nitric acid and $5 \mathrm{mM} 18$ crown-6 ether meant that flat-topped peaks of $c a .3$ min duration were produced, ideally suited for high precision strontium isotope ratio measurement. Ratios of ${ }^{87} \mathrm{Sr} /{ }^{86} \mathrm{Sr}$ were measured in apples, ciders, leaves and soil as part of an origin authentication project. Plant uptake was also a focus of work by Becker et al. ${ }^{288}$. They successfully used a quadrupole ICP-MS instrument, with an octopole collision cell, to monitor the effects of root temperature on the uptake by Hordeum vulgare (barley) of a nutrient solution, isotopically enriched with ${ }^{25} \mathrm{Mg},{ }^{44} \mathrm{Ca}$ and ${ }^{41} \mathrm{~K}$. Wiederhold et al. ${ }^{289}$ used MC-ICP-MS, together with total digestion and sequential extraction, in a study of the isotopic fractionation of iron during its transformation and re-distribution in soil.

Quadrupole ICP-MS continues to be a popular alternative to TIMS for lead isotope ratio measurement; although the precision is poorer it is sufficient for many environmental applications with the advantages of simplified sample preparation and higher sample throughput. The interference of high uranium concentrations on accurate measurement of $\mathrm{Pb}$ isotope ratios has been noted by Santos et al. ${ }^{290}$, whilst Margui et al. ${ }^{291}$ needed to apply a correction, based on ${ }^{202} \mathrm{Hg}$, for the isobaric interference arising from ${ }^{204} \mathrm{Hg}$ in their study of $\mathrm{Pb}$ and $\mathrm{Zn}$ in mining areas in Spain. De Muynck et al. ${ }^{292}$ were able to obtain $\mathrm{Pb}$ isotope ratios similar to those from MCICP-MS and TIMS by using Ne as the collision gas in a DRC ICP-MS instrument. The method, which also involved optimised sample digestion and lead preconcentration procedures, was intended chiefly for archaeological analysis but has wider applicability.

A method for calculating the contribution of polyatomic species to background in quantification of ultra-low concentrations of $P u$ isotopes was described by Pointurier et $a l^{293}$. In a different study, pre-concentration of $\mathrm{Pu}$, with simultaneous 
removal of interferents such as $U$, was achieved by on-line coupling of a column of Eichrom TEVA resin to ICP-MS ${ }^{294}$. The method was reported to be suitable for rapid measurement of ${ }^{239} \mathrm{Pu}$ and ${ }^{240} \mathrm{Pu}$ in soil and sediment samples. Speed of analysis was a key factor also in work by Greis et al. ${ }^{295}$ who conducted a detailed evaluation of alternative strategies for extraction, pre-concentration and isolation of $\mathrm{Pu}$ from environmental samples (water, soil and sediment) in order to define the best approaches for use in nuclear emergencies.

On-line coupling of a Dionex IonPac AS16 column to ICP-MS has allowed the quantification of organophosphate herbicides ${ }^{296}$. Richardson and Caruso ${ }^{121}$ used GC-ICP-MS to measure the degradation products of phosphorus-containing chemical warfare agents, such as Sarin and VX.

\subsubsection{Accelerator mass spectrometry}

The majority of work on AMS reported in the past year involved radiocarbon dating, often used in association with other metrics, such as measurement of additional radionuclides or the presence of tephra layers, to increase confidence in the chronologies of peat and other stratified soil and sediment systems. In terms of new developments, D'Elia et al. ${ }^{297}$ suggested the use of ATR-FTIR in preliminary screening of bone samples intended for ${ }^{14} \mathrm{C}$ dating. This allowed contaminants from soil or sample preservation treatments, which could otherwise compromise the accuracy of results, to be detected. Whitehead et al. ${ }^{298}$ proposed a new application of ${ }^{10} \mathrm{Be}$ AMS: the forensic investigation of historical nuclear bomb sites. They determined the $(n, \alpha)$ cross-section for production of ${ }^{10} \mathrm{Be}$ from ${ }^{13} \mathrm{C}$ by irradiation of graphite targets in a nuclear reactor, then used this value, together with estimates of the amounts of carbon-containing materials in typical bomb components, to calculate approximate levels of ${ }^{10} \mathrm{Be}$ produced in nuclear explosions. Analysis of environmental samples, mainly soils, from Hiroshima and Nagasaki, Japan and from Semipalatinsk, Kazakhstan, confirmed the presence of significantly enhanced ${ }^{10} \mathrm{Be}$ levels, relative to cosmogenic background concentrations, at these locations. Child et al. ${ }^{299}$ described a method for determining $\mathrm{Pu}$ concentrations and ${ }^{240} \mathrm{Pu} /{ }^{239} \mathrm{Pu}$ isotope ratios that was successfully applied to samples $(0.5-2.0 \mathrm{~g})$ containing analytes at femtogram levels. Satisfactory agreement with certified values was obtained for a range of soil and sediment CRMs. The use of AMS in place of INAA in the determination of ${ }^{129} \mathrm{I}$ 
continues to be of interest and various methods for improved or simplified extraction of this radionuclide have been reported recently ${ }^{91,300,301}$.

\subsubsection{Laser-induced breakdown spectroscopy}

Idris et al. ${ }^{302}$ used a transversely-excited atmospheric $\mathrm{CO}_{2}$ laser $(\lambda=10.6 \mu \mathrm{m})$ in LIBS analysis of soil. The laser was operating at lower power density $\left(0.25 \mathrm{GW} \mathrm{cm}^{-}\right.$ ${ }^{2}$ at $\left.750 \mathrm{~mJ}\right)$ and longer pulse length (200 ns) than the Nd:YAG usually employed. The sample was presented as small particles trapped in microholes in a specially designed nickel target. Advantages claimed for the system included reduced loss of sample particles during laser irradiation, enhanced atomisation, due to confinement of the sample, and enhanced excitation, due to metal-assisted gas breakdown. Ablation of the nickel target was minimal because the metal has an ablation threshold higher than the laser power density employed. In another interesting example, LIBS measurements were carried out on soil and rocks at subzero temperatures and under reduced pressure to assess the potential of the technique in the future exploration of the surface composition of Mars ${ }^{303}$.

Progress has been made in the application of LIBS to plants. Single-shot LIBS spectra were obtained across transects of air-dried leaves of Helianthus annus by means of a frequency-doubled Nd:YAG laser at $532 \mathrm{~nm}$, with a $5 \mathrm{~ns}$ pulse ${ }^{304}$. The plants had been grown hydroponically in media containing different concentrations of lead acetate. Results showed the effects of $\mathrm{Pb}$ uptake on the spatial distribution of $\mathrm{Mn}$ and $\mathrm{K}$ in the leaf tissue. In another study ${ }^{305}$ the application of femtosecond-LIBS (Ti:sapphire laser at $800 \mathrm{~nm}$, with $150 f_{s}$ pulses) to Sophora japonica allowed sampling sites to be ranked according to approximate levels of pollutant metal in atmospheric particles accumulated on the upper surface of leaves.

\subsubsection{X-ray techniques}

Popular topics include the application of X-ray based spatial mapping techniques to study the uptake and distribution of trace elements in plants; and the application of multiple X-ray based techniques, or of X-ray techniques together with other analytical approaches, to obtain information on trace element speciation.

Tylko et al. ${ }^{306}$ conducted the first micro-PIXE analysis under vacuum of frozen-hydrated biological samples: leaves of Senecio anomalochrous and larvae of 
the beetle Chysalina pardalina. A commercially available cryotransfer system, normally used in electron microscopy, was adapted for this work. Specimens were mounted on a cold stage maintained at around $100 \mathrm{~K}$. Detection limits down to $1 \mu \mathrm{g} \mathrm{g}^{-}$ 1, on a wet mass basis, were obtained with a proton beam current of $150 \mathrm{pA}$. Elemental maps obtained from frozen-hydrated specimens were similar to those obtained after freeze-drying, with the advantage that the samples retained their full water content and so potential artefacts arising from the drying process were avoided. Seigele et al. ${ }^{307}$ also carried out high-resolution PIXE mapping of metals in leaves and commented on the relative merits of different sample preparation strategies: freezedrying and a freeze-substitution technique employing THF were compared. Superior spatial resolution was obtained with freeze-substitution. However, comparison with bulk analysis by ICP-AES indicated that significant losses of analytes occurred during sample preparation, which was not the case with freeze-drying.

Tsutsumimoto and Tsuji ${ }^{308}$ used XRF in real-time monitoring of the uptake of $\mathrm{Ca}, \mathrm{Cu}, \mathrm{Fe}, \mathrm{K}, \mathrm{Mn}$ and $\mathrm{Zn}$, from a nutrient solution into Stevia rebaudiana, showing clearly the different rates of translocation of the analytes from stem to leaves.

Arsenic uptake and distribution in plants has been studied. Cucumis sativus (cucumber) was grown under hydroponic conditions in solutions containing arsenite or arsenate ${ }^{309}$. Synchrotron radiation-induced XANES of nutrient solutions and xylem sap indicated that inter-conversion occurred between the As species as they were taken up by the plant. Smith et al. ${ }^{475}$ also observed the reduction of arsenate to arsenite during plant uptake in studies of Rhaphanus sativus (radish). Arsenic(III)sulfur compounds were identified in the leaf and stem of living plants by XANES, although arsenate was the predominant form supplied in both hydroponic experiments and in pot experiments where plants were grown in soil contaminated with arsenicrich mine waste. In another study ${ }^{310}$, synchrotron-based XRF mapping indicated that As was distributed throughout the grain of white rice, but located mainly at the surface of grains of brown rice: this latter finding was confirmed by LA-ICP-MS. Both direct $\mu$-XANES of grains, and HPLC-ICP-MS of grain extracts, revealed the presence of inorganic arsenic species and DMA in the rice, but the proportions found differed between the two techniques.

Voegelin et al. ${ }^{311}$ applied an array of X-ray based techniques to determine arsenic speciation in soil. They studied As-contaminated, riparian floodplain soils, 
which are of interest in investigating redox control on trace element speciation since intermittent flooding leads to reducing soil conditions, whereas the area around a root is maintained in an oxic state by diffusion of oxygen from the plant. Synchrotron $\mu$ XRF spectrometry of soil sections showed that concentrations of As, Fe and Mn were enhanced in the vicinity of the root, and that the distribution of As closely resembled that of Fe. XANES indicated that As was predominantly present as $\mathrm{As}^{\mathrm{V}}$. Spectra obtained from soil most closely matched reference spectra of $\mathrm{As}^{\mathrm{V}}$ absorbed on ferrihydrite. Detailed analysis and shell-modelling of EXAFS spectra confirmed that As was associated with Fe-containing phases, most probably oxyhydroxides, and this was supported by the results of ICP-AES analysis of oxalate extracts of soils. 
Table 3. Pre-concentration methods involving cloud point extraction used in the analysis of soils, plants and related materials

\begin{tabular}{|c|c|c|c|c|c|c|c|c|}
\hline Analyte(s) & Matrix & Digestion & Surfactant & Chelator & Detector & Notes & CRMs & Ref \\
\hline $\mathrm{Ag}$ & $\begin{array}{l}\text { Soil, } \\
\text { sediment, } \\
\text { ore }\end{array}$ & $\begin{array}{l}\mathrm{HNO}_{3} / \\
\mathrm{HClO}_{4}\end{array}$ & $\begin{array}{l}\text { Triton } \\
\mathrm{X}-114\end{array}$ & $\begin{array}{l}\text { Diethyldithio } \\
\text { Carbamate } \\
\text { (DDTC) }\end{array}$ & $\begin{array}{l}\text { TS-FF- } \\
\text { AAS }\end{array}$ & $\begin{array}{l}\text { Sensitivity enhancement } 21 . \text { LOD } \\
0.2 \mu \mathrm{g} \mathrm{L}^{-1} . \mathrm{RSD}=3.1 \% \text { at } 5 \mu \mathrm{g} \mathrm{L}^{-1} \\
(\mathrm{n}=7) .\end{array}$ & $\begin{array}{l}\text { GBW } 07401 \\
\text { Soil, } \\
\text { 07402 Soil, } \\
\text { 07405 Soil, } \\
\text { 07309 Marine } \\
\text { sediment, } \\
\text { 07260 Silver } \\
\text { ore }\end{array}$ & 272 \\
\hline $\mathrm{Au}, \mathrm{Pd}, \mathrm{Pt}$ & Road dust & $\begin{array}{l}\text { Microwave; } \\
\text { Aqua regial } \\
\mathrm{HF}\end{array}$ & $\begin{array}{l}\text { Triton } \\
\text { X-114 }\end{array}$ & $\begin{array}{l}\text { N,N-dihexyl- } \\
\text { N'- } \\
\text { benzoylthiourea }\end{array}$ & ICP-MS & $\begin{array}{l}\text { Preconcentration factor } \sim 100 . \\
\text { LOD } \sim 6 \mathrm{pg} \mathrm{mL} \mathrm{m}^{-1} \text { for } \mathrm{Au}, \sim 0.5 \mathrm{pg} \\
\mathrm{mL}^{-1} \text { for } \mathrm{Pt} \text { and } \mathrm{Pd} \text {. RSD }<3.0 \% \text { at } \\
50 \mathrm{pg} \mathrm{mL}^{-1} \text {. }\end{array}$ & $\begin{array}{l}\text { BCR CRM } \\
723 \text { Road } \\
\text { dust; NIST } \\
\text { SRM 2709 } \\
\text { San Joaquin } \\
\text { soil }\end{array}$ & 312 \\
\hline $\mathrm{Co}, \mathrm{Cr}$ & Leaves & $\begin{array}{l}\text { Microwave; } \\
\mathrm{HNO}_{3} / \mathrm{H}_{2} \mathrm{O}_{2}\end{array}$ & $\begin{array}{l}\text { Triton } \\
\text { X-114 }\end{array}$ & $\begin{array}{l}\text { 2-(5-bromo-2- } \\
\text { pyridylazo)-5- } \\
\text { (diethylamino)- } \\
\text { phemol }\end{array}$ & ETAAS & $\begin{array}{l}\text { Enrichment factors } 41 \text { and } 26 \text {; } \\
\text { LOD } 12 \text { and } 23 \mathrm{ng} \mathrm{L}^{-1} ; \mathrm{RSD} 8.4 \\
\text { and } 5.4 \% \text { at } 0.5 \mu \mathrm{g} \mathrm{L}^{-1}(\mathrm{n}=8) \text { for } \\
\text { Co and } \mathrm{Cr} \text {, respectively. }\end{array}$ & $\begin{array}{l}\text { NIST SRM } \\
1515 \\
\text { Apple leaves }\end{array}$ & 313 \\
\hline $\mathrm{Co}, \mathrm{Cu}, \mathrm{Ni}$ & $\begin{array}{l}\text { Blood, } \\
\text { chocolate, } \\
\text { liver, soil, } \\
\text { spinach, } \\
\text { water }\end{array}$ & $\mathrm{HNO}_{3} / \mathrm{H}_{2} \mathrm{O}_{2}$ & $\begin{array}{l}\text { Triton } \\
\mathrm{X}-114\end{array}$ & $\begin{array}{l}\text { Methyl-2- } \\
\text { pyridylketone } \\
\text { oxime (MPKO) }\end{array}$ & FAAS & $\begin{array}{l}\text { Enrichment factors } \sim 60 . \mathrm{LOD} \sim \\
2.0 \mathrm{ng} \mathrm{mL}^{-1} . \mathrm{RSD}<2 \% \\
\text { (concentration and } \mathrm{n} \text { unspecified). }\end{array}$ & $\begin{array}{l}\text { None (spike } \\
\text { and recovery) }\end{array}$ & 233 \\
\hline V & Soil & $\begin{array}{l}\mathrm{HF} / \mathrm{H}_{2} \mathrm{SO}_{4} / \\
\mathrm{HClO}_{4}\end{array}$ & $\begin{array}{l}\text { Triton } \\
\text { X-100 }\end{array}$ & Methylene blue & ETAAS & $\begin{array}{l}\text { Enrichment factor } 10 \text {. LOD } 0.7 \mathrm{ng} \\
\mathrm{mL}^{-1} . \mathrm{RSD} 4.3 \% \text { at } 50 \mathrm{ng} \mathrm{mL}^{-1}(\mathrm{n} \\
=5) .\end{array}$ & $\begin{array}{l}\text { Standard } \\
\text { Tibet soil } \\
83401 \\
\end{array}$ & 314 \\
\hline
\end{tabular}


Table 4. Pre-concentration methods involving solid phase extraction used in the analysis of soils, plants and related materials

\begin{tabular}{|c|c|c|c|c|c|c|c|}
\hline Analyte(s) & Matrix & Substrate coating & $\begin{array}{l}\text { Column } \\
\text { substrate }\end{array}$ & $\begin{array}{l}\text { Detecto } \\
\mathbf{r}\end{array}$ & Notes & CRMs & Ref \\
\hline $\mathrm{Cd}$ & $\begin{array}{l}\text { Cabbage, } \\
\text { guarana }\end{array}$ & $\begin{array}{l}\text { 2-(2-thiazolylazo)- } \\
\text { 5-dimethylammino } \\
\text { phenol }\end{array}$ & $\begin{array}{l}\text { Amberlite } \\
\text { XAD-2 }\end{array}$ & $\begin{array}{l}\text { On-line } \\
\text { TS-FF- } \\
\text { AAS }\end{array}$ & $\begin{array}{l}\text { Pre-concentration factor } 24 . \text { LOD } \\
8.0 \mathrm{ng} \mathrm{L}^{-1} . \text { RSD } 6.1 \% \text { at } 0.5 \mu \mathrm{g} \mathrm{L} \\
{ }^{-}\end{array}$ & $\begin{array}{l}\text { NIST SRM } 1515 \\
\text { Apple leaves, NBS } \\
1571 \text { Orchard leaves, } \\
\text { NIES 10b Rice flour }\end{array}$ & 315 \\
\hline $\mathrm{Cd}, \mathrm{Cu}$ & Plants & $\begin{array}{l}\text { Cyanopropylsilane. } \\
\text { (Analytes as } 1,10- \\
\text { phenanthroline } \\
\text { chelates). }\end{array}$ & Silica gel & $\begin{array}{l}\text { ICP- } \\
\text { AES }\end{array}$ & $\begin{array}{l}\text { Pre-concentration factors } 60 \text { and } \\
120 ; \mathrm{LODs} 0.18 \text { and } 0.07 \mu \mathrm{g} \mathrm{L}^{-1} \text {, } \\
\text { for } \mathrm{Cd} \text { and } \mathrm{Cu} \text {, respectively. RSD } \\
<1.5 \% \text {. }\end{array}$ & $\begin{array}{l}\text { CTA-OTL-1 Oriental } \\
\text { tobacco leaves }\end{array}$ & 316 \\
\hline $\mathrm{Cd}, \mathrm{Cu}$ & Water & Bacillus subtilis & $\begin{array}{l}\text { Amberlite } \\
\text { XAD-4 }\end{array}$ & FAAS & & $\begin{array}{l}\text { NRCC-SLRS-4 } \\
\text { Riverine water, LGC } \\
7162 \text { Strawberry } \\
\text { leaves }\end{array}$ & 317 \\
\hline $\mathrm{Cd}, \mathrm{Ni}$ & Tobacco & 2-aminothiophenol & $\begin{array}{l}\text { Amberlite } \\
\text { XAD-4 }\end{array}$ & $\begin{array}{l}\text { On-line } \\
\text { FAAS }\end{array}$ & $\begin{array}{l}\text { Pre-concentration factors } 99 \text { and } \\
43 \text {, LODs } 0.3 \text { and } 0.8 \mu \mathrm{g} \mathrm{L}^{-1} \text {, for } \\
\text { Cd and Ni, respectively. }\end{array}$ & $\begin{array}{l}\text { NIST SRM 1570a } \\
\text { Spinach leaves }\end{array}$ & 318 \\
\hline $\mathrm{Cd}, \mathrm{Pb}$ & $\begin{array}{l}\text { Vegetables, } \\
\text { water }\end{array}$ & $\begin{array}{l}\text { (Analytes as 1- } \\
\text { nitroso-2-naphthol- } \\
\text { 3,6-disulfonic acid } \\
\text { chelates) }\end{array}$ & $\begin{array}{l}\text { Ram horn } \\
\text { powder }\end{array}$ & FAAS & $\begin{array}{l}\text { Pre-concentration factor } 50 . \text { LODs } \\
1.7 \text { and } 5.6 \mathrm{ng} \mathrm{mL}^{-1}, \text { for } \mathrm{Cd} \text { and } \\
\mathrm{Pb} \text {, respectively. RSD }<8 \% \text {. }\end{array}$ & $\begin{array}{l}\text { GBW } 07605 \text { Tea } \\
\text { leaves, IAEA } 407 \\
\text { Fish tissue }\end{array}$ & 319 \\
\hline $\mathrm{Cd}, \mathrm{Pb}$ & $\begin{array}{l}\text { Blood, pine } \\
\text { leaf, water }\end{array}$ & $\begin{array}{l}\text { Ammonium } \\
\text { pyrrolidine } \\
\text { dithiocarbamate }\end{array}$ & $\begin{array}{l}\text { Microcrystalli } \\
\text { ne } \\
\text { naphthaline }\end{array}$ & $\begin{array}{l}\text { On-line } \\
\text { FAAS }\end{array}$ & $\begin{array}{l}\text { Pre-concentration factors } 53 \text { and } \\
65, \mathrm{RSD} 3.6 \% \text { and } 2.7 \% \text {, for } \mathrm{Cd} \\
\text { and } \mathrm{Pb} \text {, respectively. }\end{array}$ & $\begin{array}{l}\text { None (spike and } \\
\text { recovery, and } \\
\text { comparison with } \\
\text { ETAAS) }\end{array}$ & 320 \\
\hline $\begin{array}{l}\mathrm{Cd}, \mathrm{Co}, \mathrm{Cr} \\
\mathrm{Mn}, \mathrm{Ni}, \mathrm{Pb}\end{array}$ & $\begin{array}{l}\text { Fish, rice, } \\
\text { urine, water, } \\
\text { wine }\end{array}$ & $\begin{array}{l}\text { Bacillus } \\
\text { thuringiensis }\end{array}$ & $\begin{array}{l}\text { Chromosorb } \\
101\end{array}$ & FAAS & LODs $0.4-2.8 \mu \mathrm{g} \mathrm{L}^{-1}$ & $\begin{array}{l}\text { IAEA } 336 \text { Lichen, } \\
\text { NIST SRM 1573a } \\
\text { Tomato }\end{array}$ & 321 \\
\hline
\end{tabular}




\begin{tabular}{|c|c|c|c|c|c|c|c|}
\hline $\begin{array}{l}\mathrm{Cd}, \mathrm{Co}, \mathrm{Cu}, \\
\mathrm{Fe}, \mathrm{Mn}, \mathrm{Ni} \\
\mathrm{Pb}\end{array}$ & $\begin{array}{l}\text { Lichen, } \\
\text { moss, } \\
\text { mushroom, } \\
\text { table salt, } \\
\text { water }\end{array}$ & $\begin{array}{l}\text { Penicillium } \\
\text { italicum }\end{array}$ & $\begin{array}{l}\text { Sepabeads SP } \\
70\end{array}$ & FAAS & LODs $0.4-1.6 \mu \mathrm{g} \mathrm{L}^{-1}$ & $\begin{array}{l}\text { IAEA } 336 \text { Lichen, } \\
\text { NIST SRM 1573a } \\
\text { Tomato leaves }\end{array}$ & 322 \\
\hline $\begin{array}{l}\mathrm{Cd}, \mathrm{Co}, \mathrm{Cu}, \\
\mathrm{Fe}, \mathrm{Mn}, \mathrm{Ni} \\
\mathrm{Pb}, \mathrm{Zn}\end{array}$ & Kale, water & $\begin{array}{l}\text { (Analytes as diethyl } \\
\text { dithiocarbamate } \\
\text { chelates) }\end{array}$ & $\begin{array}{l}\text { Amberlite } \\
\text { XAD-2000 }\end{array}$ & FAAS & LODs $0.15-0.45 \mu \mathrm{g} \mathrm{L}^{-1}$. & $\begin{array}{l}\text { CRM NIES No.7 Tea } \\
\text { leaves, TMDW-500 } \\
\text { Drinking water }\end{array}$ & 181 \\
\hline $\begin{array}{l}\mathrm{Cd}, \mathrm{Co}, \mathrm{Cu}, \\
\mathrm{Fe}, \mathrm{Mn}, \mathrm{Ni} \\
\mathrm{Pb}, \mathrm{Zn}\end{array}$ & Water & $\begin{array}{l}\text { (Analytes as } 8- \\
\text { hydroxyquinoline } \\
\text { chelates) }\end{array}$ & $\begin{array}{l}\text { Amberlite } \\
\text { XAD-2010 }\end{array}$ & FAAS & LODs $0.10-0.40 \mu \mathrm{g} \mathrm{L}^{-1}$. & $\begin{array}{l}\text { CRM NIES No. } 7 \text { Tea } \\
\text { leaves, TMDW-500 } \\
\text { Drinking water }\end{array}$ & 180 \\
\hline $\begin{array}{l}\mathrm{Cd}, \mathrm{Co}, \mathrm{Cu}, \\
\mathrm{Ni}, \mathrm{Pb}, \mathrm{Zn}\end{array}$ & $\begin{array}{l}\text { Chickpea, } \\
\text { fish, } \\
\text { tobacco, } \\
\text { tomato } \\
\text { sauce, water }\end{array}$ & $\begin{array}{l}\text { (Analytes as } \\
\text { ammonium } \\
\text { pyrrolidine } \\
\text { dithiocarbamate } \\
\text { chelates) }\end{array}$ & $\begin{array}{l}\text { Multiwalled } \\
\text { carbon } \\
\text { nanotubes }\end{array}$ & FAAS & LODs $0.30-0.60 \mu \mathrm{g} \mathrm{L}^{-1}$. & $\begin{array}{l}\text { NIST RM } 8418 \\
\text { Wheat gluten, SRM } \\
1515 \text { Apple leaves, } \\
\text { LGC } 6010 \text { Hard } \\
\text { drinking water }\end{array}$ & 1777 \\
\hline $\begin{array}{l}\mathrm{Cd}, \mathrm{Cu}, \mathrm{Cr}, \\
\mathrm{Ni}, \mathrm{Pb}\end{array}$ & $\begin{array}{l}\text { Cabbage, } \\
\text { guarana }\end{array}$ & $\begin{array}{l}\text { Dihydroxylbenzoic } \\
\text { acid }\end{array}$ & $\begin{array}{l}\text { Amberlite } \\
\text { XAD-4 }\end{array}$ & $\begin{array}{l}\text { ICP- } \\
\text { AES }\end{array}$ & $\begin{array}{l}\text { Pre-concentration factors } 100,72 \text {, } \\
19,91 \text { and } 53 \text { for } \mathrm{Cd}, \mathrm{Cu}, \mathrm{Cr}, \mathrm{Ni} \\
\text { and } \mathrm{Pb} \text {, respectively . LODs } 0.02- \\
0.60 \mu \mathrm{g} \mathrm{L}^{-1} \text {. }\end{array}$ & $\begin{array}{l}\text { NIST SRM } 1571 \\
\text { Orchard leaves }\end{array}$ & 323 \\
\hline $\begin{array}{l}\mathrm{Co}, \mathrm{Cu} \\
\mathrm{Mn}, \mathrm{Ni}, \mathrm{U} \\
\text { Th, Zn }\end{array}$ & Soil & $\begin{array}{l}5,10,15,20- \\
\text { tetrakis(phenoxy } \\
\text { acetic acid) } \\
\text { porphyrin }\end{array}$ & $\begin{array}{l}\text { Merrifield } \\
\text { chloromethyla } \\
\text { ted resin } \\
\text { beads }\end{array}$ & $\begin{array}{l}\text { FAAS } \\
\text { (or } \\
\text { UV/vis) }\end{array}$ & Pre-concentration factors $115-215$. & $\begin{array}{l}\text { NIST SRM } 2709 \text { San } \\
\text { Joaquin soil }\end{array}$ & 324 \\
\hline $\mathrm{Co}, \mathrm{Cu}, \mathrm{Ni}$ & $\begin{array}{l}\text { Blood, soil, } \\
\text { vegetables, } \\
\text { water }\end{array}$ & $\begin{array}{l}\text { Dithioxamide } \\
\text { (rubeanic acid) }\end{array}$ & $\begin{array}{l}\text { Activated } \\
\text { carbon }\end{array}$ & FAAS & $\begin{array}{l}\text { Pre-concentration factor } 330 . \\
\mathrm{LODs} 0.80,0.50 \text { and } 0.75 \mu \mathrm{L} \mathrm{L}^{-1} \\
\text { for } \mathrm{Co}, \mathrm{Cu} \text { and } \mathrm{Pb} \text {, respectively. } \\
\mathrm{RSD}<2 \%(\mathrm{n}=3) \text {. }\end{array}$ & $\begin{array}{l}\text { None (spike and } \\
\text { recovery) }\end{array}$ & 184 \\
\hline $\mathrm{Cr}$ & Vegetables, & & Amberlyst 36 & FAAS & LOD $1 \mu \mathrm{g} \mathrm{L}^{-1}$. RSD $2 \%$ at $100 \mu \mathrm{g}$ & GBW 07605 Tea & 325 \\
\hline
\end{tabular}




\begin{tabular}{|c|c|c|c|c|c|c|c|}
\hline & water & & & & $\begin{array}{l}\mathrm{L}^{-1}(\mathrm{n}=7) . \text { Analyte trapped as } \\
\mathrm{Cr}^{\mathrm{III}} \text {. }\end{array}$ & $\begin{array}{l}\text { leaves, IAEA } 407 \\
\text { Fish tissue }\end{array}$ & \\
\hline $\mathrm{Cr}$ & Water & & $\begin{array}{l}\text { Dowex M } \\
4195\end{array}$ & FAAS & $\begin{array}{l}\mathrm{RSD}<10 \% \text {. Analyte trapped as } \\
\mathrm{Cr}^{\mathrm{VI}} \text {. Total } \mathrm{Cr} \text { obtained following } \\
\text { oxidation with } \mathrm{H}_{2} \mathrm{O}_{2} . \mathrm{Cr} \\
\text { estimated by difference. }\end{array}$ & $\begin{array}{l}\text { NIST SRM } 2711 \\
\text { Montana soil, GBW } \\
07603 \text { Bush branches } \\
\text { and leaves }\end{array}$ & 195 \\
\hline $\mathrm{Cu}, \mathrm{Fe} \mathrm{Zn}$ & $\begin{array}{l}\text { Leaves, } \\
\text { liver, water }\end{array}$ & curcumin & $\begin{array}{l}\text { Aminopropyl } \\
\text { silica gel }\end{array}$ & $\begin{array}{l}\text { ICP- } \\
\text { AES }\end{array}$ & $\begin{array}{l}\text { LODs } 0.12,0.15 \text { and } 0.40 \text { for } \mathrm{Cu} \text {, } \\
\text { Fe and } \mathrm{Zn} \text {, respectively. RSD }< \\
3 \%(\mathrm{n}=5) \text {. }\end{array}$ & $\begin{array}{l}\text { GBW } 08301 \text { River } \\
\text { sediment }\end{array}$ & 326 \\
\hline $\mathrm{Cu}, \mathrm{Pb}$ & $\begin{array}{l}\text { Blood, soil, } \\
\text { water }\end{array}$ & $\begin{array}{l}\text { 5,5- } \\
\text { diphenylimidazolidi } \\
\text { ne-2,4-dione; 5,5- } \\
\text { diphenylimidazolidi } \\
\text { ne-2-thione-4-one; } \\
\text { 2-(4'- } \\
\text { methoxybenzyliden } \\
\text { imine) } \\
\text { thiophenole }\end{array}$ & $\begin{array}{l}\text { Activated } \\
\text { carbon }\end{array}$ & FAAS & $\begin{array}{l}\text { LODs } 0.31-0.65 \mu \mathrm{g} \mathrm{L}^{-1} . \mathrm{RSD}< \\
4 \% .\end{array}$ & $\begin{array}{l}\text { None (spike and } \\
\text { recovery) }\end{array}$ & 202 \\
\hline Dy & $\begin{array}{l}\text { Sediment, } \\
\text { soil }\end{array}$ & $\begin{array}{l}\text { Analyte imprinted } \\
\text { thenoyltrifluoro } \\
\text { acetone }\end{array}$ & Silica gel & $\begin{array}{l}\text { On-line } \\
\text { ICP- } \\
\text { AES }\end{array}$ & $\begin{array}{l}\text { Pre-concentration factor } 10 . \text { LOD } \\
0.2 \mathrm{ng} \mathrm{mL}^{-1} . \text { RSD } 1.5 \% \text { at } 40 \mathrm{ng} \\
\mathrm{mL}^{-1}(\mathrm{n}=8) .\end{array}$ & $\begin{array}{l}\text { GBW } 07401 \text { Soil; } \\
07301 \text { Sediment }\end{array}$ & 327 \\
\hline $\mathrm{Fe}$ & $\begin{array}{l}\text { Leaves, } \\
\text { liver, water }\end{array}$ & Acetylsalicylic acid & $\begin{array}{l}\mathrm{SiO}_{2} \\
\text { nanoparticles }\end{array}$ & $\begin{array}{l}\text { ICP- } \\
\text { AES }\end{array}$ & $\begin{array}{l}\text { Pre-concentration factor } 50 . \text { LOD } \\
0.49 \mathrm{ng} \mathrm{mL}^{-1} \text {. }\end{array}$ & $\begin{array}{l}\text { GBW 08301 River } \\
\text { sediment, } 08303 \\
\text { Polluted faming soil }\end{array}$ & 328 \\
\hline $\mathrm{Fe}, \mathrm{Ni}, \mathrm{Pb}$ & $\begin{array}{l}\text { Vegetables, } \\
\text { water }\end{array}$ & Aspergillis niger & Silica gel & FAAS & $\begin{array}{l}\text { Pre-concentration factor 50. LODs } \\
1.7,1.6 \text { and } 5.2 \mathrm{ng} \mathrm{mL}^{-1}, \text { for } \mathrm{Fe}, \mathrm{Ni} \\
\text { and } \mathrm{Pb} \text {, respectively. } \mathrm{RSD}<7 \% \text {. }\end{array}$ & & 329 \\
\hline
\end{tabular}




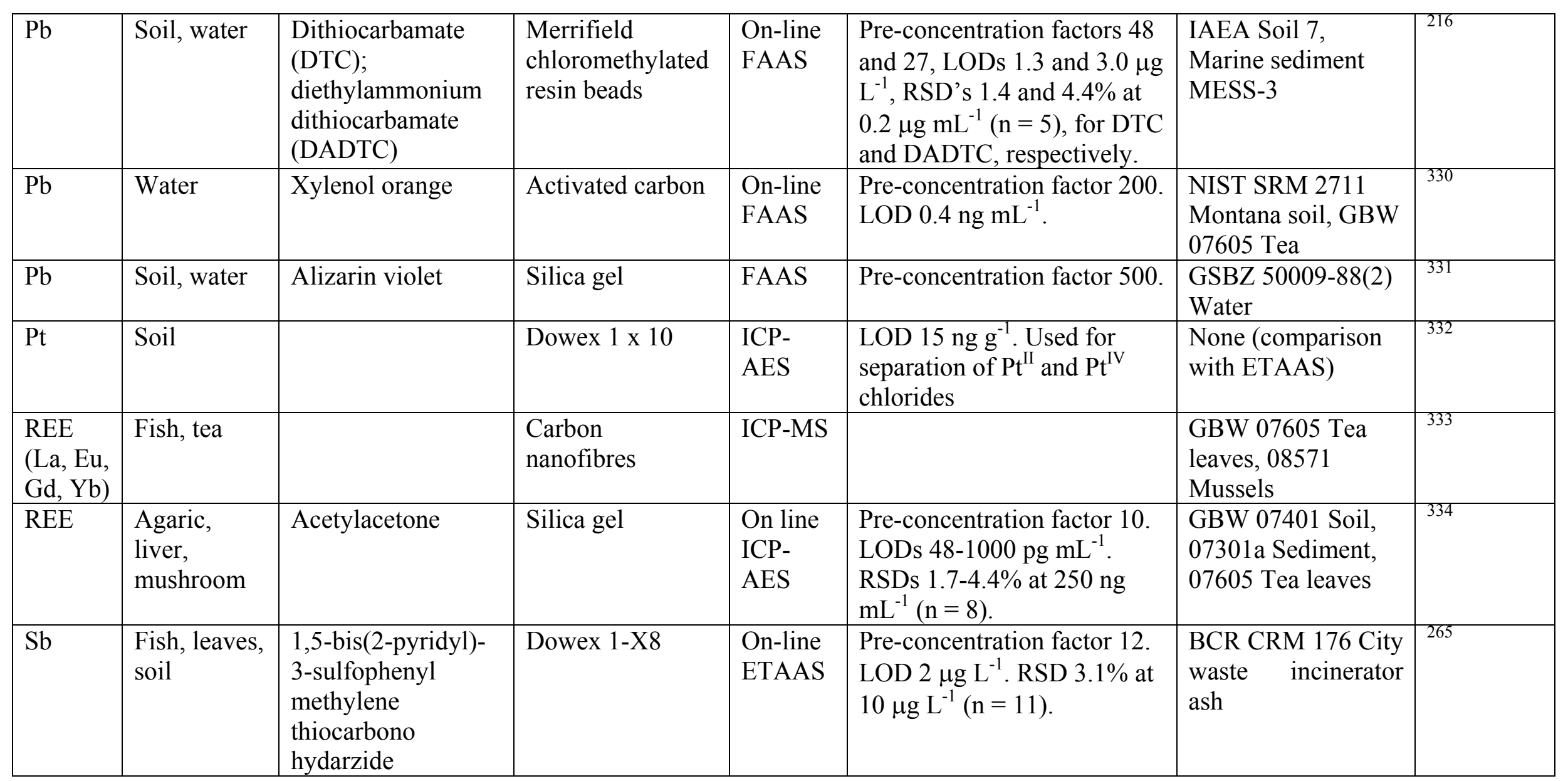


Table 5 Pre-concentration methods involving precipitation used in the analysis of soils, plants and related materials

\begin{tabular}{|c|c|c|c|c|c|c|}
\hline Analyte(s) & Matrix & Carrier & Detector & Comments & CRMs & Ref \\
\hline $\mathrm{Au}, \mathrm{Pb}, \mathrm{Pd}$ & $\begin{array}{l}\text { Dust, } \\
\text { lichen, } \\
\text { sediment, } \\
\text { soil, } \\
\text { water }\end{array}$ & $\begin{array}{l}\text { Nickel-5-methyl-4-(2- } \\
\text { thiazolylazo) } \\
\text { resorcinol }\end{array}$ & FAAS & $\begin{array}{l}\text { LODs } 1.5,2.6 \text { and } 2.1 \mu \mathrm{g} \mathrm{L}^{-1} \text { for } \\
\mathrm{Au}, \mathrm{Pb} \text { and } \mathrm{Pd} \text {, respectively. }\end{array}$ & $\begin{array}{l}\text { NIST SRM } 2711 \text { Montana } \\
\text { soil, GBW } 07309 \text { Stream } \\
\text { sediment }\end{array}$ & 336 \\
\hline $\mathrm{Co}, \mathrm{Mn}$ & $\begin{array}{l}\text { Coal, } \\
\text { honey, } \\
\text { rice, soil, } \\
\text { tea, } \\
\text { tobacco, } \\
\text { urine, } \\
\text { water }\end{array}$ & $\begin{array}{l}\text { Copper(II)-8- } \\
\text { hydroxyquinoline }\end{array}$ & FAAS & $\begin{array}{l}\text { LODs } 0.86 \text { and } 0.98 \mu \mathrm{g} \mathrm{L}^{-1} \text { for Co } \\
\text { and } \mathrm{Mn} \text {, respectively. }\end{array}$ & $\begin{array}{l}\text { NIST SRM } 2711 \text { Montana } \\
\text { soil, GBW } 07605 \text { Tea }\end{array}$ & 337 \\
\hline
\end{tabular}




\section{ANALYSIS OF GEOLOGICAL MATERIALS}

\subsection{Reference Materials}

Reviews of the use of geochemical RMs have been a regular feature in Geostandards and Geoanalytical Research for the last 25 years. The primary aim of these reviews is to provide geoanalysts with a single reference document that summarises new analytical data, methods and general issues related to the use of RMs in geoanalysis. Major developments recorded by these papers are discussed by Valladon $^{339}$ while Jochum has compiled the annual review for $2006^{340}$. Yan and Cheng ${ }^{341}$ provide an insight into the preparation and certification of well over 100 CRMs by the IGGE, China, produced primarily to satisfy the needs of their extensive geochemical mapping and exploration programme.

Isotope dilution mass spectrometry (IDMS) is used by many national metrology institutes in the characterisation of RMs for elemental concentrations and elemental species, because it offers superior accuracy and precision or the smallest measurement uncertainties when applied to appropriately prepared samples. Anyone with an interest in this subject should look no further than Vogl's comprehensive review (192 refs $)^{342}$. After some history, he covers the principles, advantages and disadvantages of the technique and four main calibration strategies. Differences in the application of TIMS and ICP-MS are discussed, together with possible sources of errors and bias. Several examples illustrate the suitability and importance of IDMS as a reference method and for RM characterisation. Isotope dilution MC-ICP-MS was used by Botha et al. ${ }^{343}$ to re-evaluate the concentrations of $\mathrm{Ba}, \mathrm{Cd}, \mathrm{Cu}, \mathrm{Mo}, \mathrm{Ni}, \mathrm{Pb}, \mathrm{Sr}$ and $\mathrm{Zn}$ in a syenite RM SARM-2 ${ }^{343}$.

The International Association of Geoanalysts (IAG) developed a protocol for $R M$ certification that applies ISO Guide 35 to the specific needs of the geoanalytical community. An important aspect of this protocol, which was published in 2003, is the pre-selection of participating laboratories so that the resulting uncertainties are fit for purpose. In a supplement to this protocol, alternative approaches to laboratory qualification, particularly through the demonstration of expert laboratory status, are proposed $^{344}$. The advantage of this approach is that it removes the requirement for the participation of a relatively large number of laboratories (between 10 and 15) for successful certification, which may be difficult to achieve for determinands such as the PGEs, halogens, $\mathrm{C}, \mathrm{In}, \mathrm{S}, \mathrm{Se}, \mathrm{Te}, \mathrm{Tl}$ and isotopic compositions. In an authoritative 
review of ISO best practices in relation to the IAG protocol, Kane and Potts ${ }^{345}$ discuss how uncertainties in certified values are estimated and make recommendations on how a laboratory should compare its results with certified values when assessing accuracy. They feel strongly that ISO should be asked to make their guides more comprehensible to users in the laboratory!

Several new geochemical CRMs are available. The IGGE $^{346}$ in China has produced three new CRMs, GPt-8 to GPt-10, each certified for 6 PGEs. Nine experienced laboratories provided data by NiS mini fire assay with Te coprecipitation, followed by measurement by ICP-MS; Os was determined by ID. These materials should be a valuable resource, particularly GPt-8, which is a soil containing about 1 ng g ${ }^{-1}$ PGEs in total, whereas the other two are ore samples with more than $1 \mu \mathrm{g} \mathrm{g}^{-1}$ of PGEs. The certification of a Brazilian basalt BRP- $1^{347}$ was conducted according to the recommendations of the IAG protocol and ISO Guide 35, with a few small variations. The homogeneity of this material was assessed for trace elements using WD-XRF and

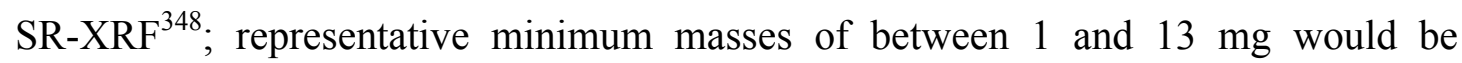
required for analysis.

Some existing CRMs have been characterised for REEs and additional trace elements omitted from the original certification. In a thorough study of two kimberlitic RMs, SARM-39 and MY-4, four digestion techniques were evaluated ${ }^{349}$. Three other well-characterised matrix-matched RMs were included as comparators. Concentrations of 34 trace elements, including all the REEs, were determined by ICPMS. Recoveries of better than $100 \pm 5 \%$ were achieved for most determinands, along with smooth chondrite-normalised plots for the REEs, showing that the data are suitable for geochemical applications. This study demonstrated, yet again, that no single method of decomposition will provide accurate data for all trace elements in all types of geological samples. In contrast, INAA, which involves minimal sample preparation, was used to acquire new trace element values on a sandy marine sediment NRCC HISS- $1^{350}$. Of the 37 elements measured, indicative data were reported for 20 additional elements, including ten REEs. The authors suggest that the NRCC should consider circulating this material for a new intercomparison exercise to extend its certification.

The advent of new generations of mass spectrometers has provided a spur to the characterisation of RMs for isotopic studies. A comparison of ${ }^{138} \mathrm{Ce} /{ }^{136} \mathrm{Ce}$ ratios in two RMs, Johnson Matthey JMC $304 \mathrm{CeO}_{2}$ and USGS basalt BCR-1, by MC-ICP-MS 
and TIMS concluded that only measurement by TIMS of $\mathrm{Ce}$ as $\mathrm{CeO}$, combined with accurate monitoring and correction of the background between the measured ion intensities, can yield sufficiently accurate and reproducible ratios for geochemical applications ${ }^{351}$. By identifying and quantifying the individual sources of error, a combined standard uncertainty of $0.002 \%$ (2 RSE) was obtained. A new RM with a ${ }^{138} \mathrm{Ce} /{ }^{136} \mathrm{Ce}$ ratio of $1.33738 \pm 0.000005$, prepared from high-purity $\mathrm{Ce}$ metal, is available for distribution. Silicon is another element that requires careful correction of background interferences when measuring isotopic variations in environmental samples by ICP-MS. Abraham et al. ${ }^{352}$ describe how they managed to resolve the ${ }^{14} \mathrm{~N}^{16} \mathrm{O}$ interference from ${ }^{30} \mathrm{Si}$ by MC-ICP-MS in high resolution mode and obtain high precision measurements of $\delta^{30} \mathrm{Si}$ and $\delta^{29} \mathrm{Si}$. A simple $\mathrm{LiBO}_{2}$ fusion followed by purification by triethylamine molybdate co-precipitation produced consistent and reproducible $\mathrm{Si}$ isotopic signatures for USGS basalts BHVO-1 and BHVO-2. The authors suggest that, as there is no rock RM certified for Si isotopes, their study is a step towards filling this gap. An inter-laboratory comparison of three other candidate $\mathrm{Si}$ isotope $\mathrm{RMs}^{353}$ showed almost no statistical difference between the mean values obtained by each participating laboratory for two of them; the notable exception was for IRMM-018, a $\mathrm{SiO}_{2}$ standard. The cause of this discrepancy was thought to be heterogeneity or contamination of this standard. Differences between laboratories were limited to $0.2 \%$ in the mean $\delta^{30} \mathrm{Si}$ value and $0.13 \%$ for $\delta^{29} \mathrm{Si}$ in a given sample. Because there is no consensus as to what material should be used as the delta zero for Se isotope analysis, it has been proposed that NIST SRM 3149 should be used for this purpose $^{354}$. This material is available in liquid form and is thus homogeneous. It has the additional advantage that it has a $\delta^{82} \mathrm{Se} /{ }^{76} \mathrm{Se}$ composition very close to that of bulk Earth, which would be convenient for geochemists. A systematic study of the concentrations and isotopic compositions of $\mathrm{Hf}, \mathrm{Nd}, \mathrm{Pb}$ and $\mathrm{Sr}$ in 12 USGS RMs by MC-ICP-MS has been undertaken ${ }^{355}$. New recommended values for ${ }^{176} \mathrm{Hf} /{ }^{177} \mathrm{Hf}$ in these RMs, with reproducibilities of around $30 \mathrm{ppm}$ for the mafic materials, were achieved by careful control of potential sources of contamination. There has been a concerted international effort to cross-calibrate several synthetic and rock RMs for Th isotope ratios by MC-ICP-MS ${ }^{356}$. Results from six laboratories were compared with published data and nominal consensus values for ${ }^{230} \mathrm{Th} /{ }^{232} \mathrm{Th}$, together with estimates of their error derived. Prytulak and colleagues ${ }^{357}$ have promoted the use of USGS BCR-2 as a secondary RM for U-Pa disequilibrium measurements in silicate rocks. 
They made twelve separate measurements of BCR-2 by MC-ICP-MS with five different ${ }^{233} \mathrm{~Pa}$ spikes over a period of 22 months to yield a ${ }^{231} \mathrm{~Pa} /{ }^{235} \mathrm{U}$ value of $0.997 \pm$ 0.013. As well as demonstrating the validity of U-Pa determinations, the RM can provide a useful check on data reduction, which has been the cause of a number of discrepancies in published values. Recommended concentrations of ${ }^{239} \mathrm{Pu},{ }^{240} \mathrm{Pu}$ and ${ }^{239+240} \mathrm{Pu}$ in IAEA-315, a marine sediment RM, were estimated from measurements by TIMS, ID-ICP-MS and alpha spectrometry ${ }^{358}$. $\mathrm{A}^{242} \mathrm{Pu} \mathrm{RM}$ was used as a spike for quantitative analysis. The main contributions to the uncertainty were the heterogeneity of the material and systematic differences between the methods employed.

The paucity of suitable matrix-matched calibration standards for microanalytical techniques has stimulated various inter-laboratory collaborations. The debate over the homogeneity of the 91500 zircon RM with respect to its Hf isotopic composition continues, with $\mathrm{Corfu}^{359}$ presenting evidence that it probably is homogeneous at the level of a tenth of an epsilon unit. A zircon from the southern part of the Bohemian Massif (Plešovice, Czech Republic) was distributed as a potential RM to several laboratories for analysis by ID-TIMS, SIMS and LA-ICP-MS ${ }^{360}$. Although there are significant variations in its trace element content, the zircon was shown to be well suited as a RM for U-Pb and Hf isotopic measurements by LA-ICP-MS, but not U-Pb dating by SIMS. The Plešovice zircon is available from the University of Bergen. Eleven synthetic silicate and phosphate glasses, prepared to match the compositions of apatite, clinopyroxene and titanite, have been shown to be homogeneous in major and trace elements down to the micrometre scale using EPMA, SIMS and LA-ICPMS ${ }^{361}$. Provisional recommended concentrations for 27 trace elements make these materials of interest to those looking for an alternative to the NIST reference glasses for the microanalysis of these accessory minerals. Ten laboratories participated in a study of a composite fossil bone, with the objective of producing a RM with an appropriate matrix and structure for studies of the bio-mineralization of bones ${ }^{362}$. Various wet chemical digestion techniques and ICP instrumention, as well as LAICP-MS, were used to characterise the material. In general, the agreement between laboratories was poor. This was attributed to the fact that the standards used to set up and calibrate the analytical systems were not matrix matched to the fossil bone composition, leading to non-spectral matrix effects during analysis. A sample dissolution and analytical protocol was advocated that would allow the material to be established as a geochemical CRM. 


\subsection{Solid sample introduction}

\subsubsection{Laser ablation ICP-MS}

Current literature shows there is great interest in the potential of femtosecond $L A-I C P-M S$ for the direct analysis of solid materials. An excellent review (60 refs) ${ }^{363}$ of the state of the art in fs LA-ICP-MS summarises the advantages of using short laser pulses and describes the fundamental differences in LA mechanisms when using short $(>1 p s)$ and ultra-short $(<1 p s)$ pulses. Various robust compact ultra-short pulse laser systems are available. These can provide significant improvements in terms of ablation efficiency, particle-size distribution, sensitivity, fractionation effects and spatial resolution. The capabilities of IR (780-800 $\mathrm{nm})$ fs laser systems for the analysis of geological materials have been studied independently by workers in France $^{364}$ and Japan ${ }^{365}$. Freydier et al. ${ }^{364}$ varied the pulse duration from 60 to $3000 \mathrm{fS}_{\mathrm{S}}$ and found that the best precision, reproducibility and accuracy were all obtained with the shortest pulse duration ( $\left.60 f_{s}\right)$ when ablating monazite, zircon and NIST reference glasses. Using the same materials, preliminary results obtained at $266 \mathrm{~nm}$ did not show any improvements over those at $800 \mathrm{~nm}$. Gonzalez and co-workers ${ }^{366}$ demonstrated that, using a $266 \mathrm{~nm} f_{s}$ laser coupled to quadrupole ICP-MS, a combination of $\sim 10 \mu \mathrm{m}$ spot size, a repetition rate of $1000 \mathrm{~Hz}$ and scan speed of 200 $\mu \mathrm{m} \mathrm{s}^{-1}$ could be successfully employed for the bulk analysis of NIST glass samples with good lateral resolution. With this high repetition rate and low energy $(\sim 30 \mu \mathrm{J})$ pulses, they obtained accuracies of approximately 14\% and precisions of $6 \%$ RSD. Horn and von Blanckenburg ${ }^{367}$ studied elemental and isotopic fractionation effects during $196 \mathrm{~nm}$ fs LA, with a pulse energy of $0.01 \mathrm{~mJ}$, coupled to MC-ICP-MS. No elemental fractionation was observed with respect to $\mathrm{Pb} / \mathrm{U}$ and $\mathrm{Th} / \mathrm{U}$ ratios within the precision of the measurements, even when the analysis was carried out without matrix-matched standards. Laser-induced isotope fractionation, seen with $n s$-LA, was also undetectable when measuring ${ }^{56} \mathrm{Fe} /{ }^{54} \mathrm{Fe}$ ratios. Precisions of better than $0.1 \%$ were achieved for a variety of matrices, close to those obtainable by solution MCICP-MS. Practical geological applications of fs LA include the in situ determination of incompatible trace elements and ore metals in individual melt inclusions in magmatic minerals ${ }^{368}$ and the in situ measurement of stable $\mathrm{Si}$ isotope ratios in a variety of silicate matrices ${ }^{369}$. 
The physical properties of particles produced on ablation continue to be examined in detail. This type of study has tended to focus on metals and silicates; consequently the behaviour of carbonate materials during LA is less well understood. Hathorne et $a l .{ }^{370}$ evaluated the chemical and physical nature of particles produced when ablating various carbonates at wavelengths of 213 and $193 \mathrm{~nm}$. Two distinct populations of particles were observed, consisting of large particles of 1-5 $\mu \mathrm{m}$ surrounded by a dendritic mesh of much finer particles approximately $10 \mathrm{~nm}$ in size. More micrometer-size particles were produced with the $213 \mathrm{~nm}$ laser than at $193 \mathrm{~nm}$, probably because of less efficient coupling with the carbonate material, and these appeared to form by photomechanical fracturing along lines of cleavage or weakness, rather than by hydrodynamic sputtering generally observed for silicates. Analysis suggested that little elemental fractionation occurred while ablating biogenic carbonates or during transport to the plasma, in contrast to the fractionation observed when ablating a silicate glass. This difference relates directly to the different mechanisms by which the particles are produced. A calcite powder pellet was found to be a suitable external standard for the analysis of a variety of biogenic carbonates, including aragonite.

Various strategies have been proposed for the production of matrix-matched standards for LA. The sol-gel method has been used to prepare calibration standards and soil samples for the determination of $\mathrm{Cr}, \mathrm{Cu}, \mathrm{Ni}, \mathrm{Pb}$ and $\mathrm{Zn}$ by LA-ICP-AES ${ }^{276}$. The highly homogeneous distribution of the scandium internal standard in the pellet improved the accuracy and precision of the technique, giving a repeatability of $2.5-$ $7 \%$ RSD between ablations for all elements of interest. Multielement calibration standards suitable for the determination of Se and $\mathrm{S}$ in sulfide minerals by LA-ICPMS were also fabricated using a sol-gel process ${ }^{371}$. The xerogels produced were examined by SEM and EPMA to assess their homogeneity; their Se and S contents were quantified using glass standards, sulfide RMs and natural sulfides with known S and Se concentrations. Although the xerogels were found to be suitable for the calibration of glasses and silicate matrices, they did not provide accurate results for $\mathrm{S}$ and $\mathrm{Se}$ in other matrices such as sulfides. Wohlgemuth-Ueberwasser et al. ${ }^{372}$ developed a method of synthesizing PGE sulfide standards for LA-ICP-MS. The sulfide starting materials were made from $\mathrm{Cu}, \mathrm{Fe}$ and Ni metal powders and elemental sulfur, the PGEs were added as chloride solutions and Re as a nitrate solution. After synthesis at atmospheric pressure, the sulfides were sintered at 1.5 to $2.0 \mathrm{GPa}$ to 
obtain pellets with the correct theoretical density. Sample heterogeneity was shown to depend on the starting metal to $\mathrm{S}$ ratio and the major element composition of the sulfide, as well as on more subtle factors such as oxygen partial pressure during synthesis, run temperature and degree of partial melting. They concluded that NiS is an unsuitable matrix for a PGE sulfide standard and therefore do not recommend the use of NiS fire assay buttons as standards for LA. Dewaele and coworkers ${ }^{373}$ modified a welding technique to produce artificial iron sulfide crystals by resistance heating a mixture of $\mu \mathrm{m}$-size particles of pyrite and pure elements in graphite electrodes. They produced a matrix-matched standard with homogeneity of $15 \%$ RSD or better for Co, $\mathrm{Cu}, \mathrm{Ga}$ and $\mathrm{Ni}$, which was deemed sufficient for semi-quantitative analysis by LAICP-MS. Poor precisions ( $>15 \%$ RSD) were obtained for $\mathrm{Pb}$, Se and $\mathrm{Zn}$. The method has the virtue of being quick and simple but has several shortcomings, such as poor control over the temperature during heating, leading to the loss of volatile elements, and the small amount of material produced. A rather more accurate approach to the determination of $\mathrm{Cu}, \mathrm{Pb}, \mathrm{Sn}$ and $\mathrm{Zn}$ in soil and sediment samples, based on solidspiking ID, has been devised by Fernández et al. ${ }^{281}$. Appropriate amounts of spike solutions of ${ }^{65} \mathrm{Cu},{ }^{207} \mathrm{~Pb},{ }^{119} \mathrm{Sn}$ and ${ }^{66} \mathrm{Zn}$ were added to IRMM CRM 142R, Trace elements in a light sandy soil, and homogenised by manual shaking. After drying, the isotopically-enriched solid spike was ground in an agate mortar to a fine powder. Sample and solid spike were mixed in equal amounts and pressed into $3 \mathrm{~mm}$ diameter pellets. During analysis by fs LA-ICP-MS, the laser repetition rate and ablation mode were selected carefully in order to reduce the effect of local inhomogeneities on the precision of the measurements. When tested on several soils and sediment CRMs, the procedure yielded concentrations that were in agreement with certified values and those obtained by ID-ICP-MS after microwave digestion of the solid samples. Precisions of less than $10 \%$ for $\mathrm{Cu}, \mathrm{Pb}$ and $\mathrm{Zn}$ were similar to those achieved by Boulyga et al. ${ }^{374}$ who used liquid spikes for the determination of heavy metals in powdered coal samples by ID LA in combination with SF-ICP-MS. Higher RSDs observed for elements such as $\mathrm{Cd}$ and $\mathrm{Hg}$ were caused by inhomogeneities resulting from micro-inclusions in the coal.

One of the main advantages of bulk analysis of geological samples by LA-ICP$M S$ is the minimum sample preparation required. Stoll and coworkers ${ }^{375}$ prepared homogenous fused glasses from $40 \mathrm{mg}$ of rock powder, without the addition of any flux, by melting the material on an automated iridium-strip heater. The temperature 
and melting time were optimised to minimise the loss of volatile elements. Using compromise conditions of $1600{ }^{\circ} \mathrm{C}$ and $10 \mathrm{~s}$, major elements and more than 30 trace elements were determined with a precision of 2-3\% (1 RSD) in samples with $\mathrm{SiO}_{2}$ contents between 47 and $59 \% \mathrm{~m} / \mathrm{m}$. Most of the analytical data agreed with reference values within the $95 \%$ confidence limits but some volatile trace elements, such as Ge, $\mathrm{In}, \mathrm{Pb}$ and $\mathrm{Sn}$, were lost under these standard conditions. Nehring et al. ${ }^{376}$ extended the application of this technique to rocks with $>55 \%$ silica by dilution with high purity $\mathrm{MgO}$ and applying hot and long melting to achieve homogeneous glasses and eliminate all residual minerals, particularly the refractory phases. Melting conditions of $1600{ }^{\circ} \mathrm{C}$ for $20 \mathrm{~s}$ were recommended for $\mathrm{SiO}_{2}$ contents between 55 and $70 \%$, whereas $1800{ }^{\circ} \mathrm{C}$ for $20-30 \mathrm{~s}$ were often required for samples containing more than $70 \%$ silica.

The challenges presented in the determination of PGEs in environmental samples by LA-ICP-MS and other techniques have been reviewed ${ }^{377}$. Although it may be possible to overcome various interferences through the use of collision or reaction cell technology, the sensitivity of LA-ICP-MS may be a significant limitation because of the low abundance of the PGEs, unless the diameter of the ablated area can be increased substantially.

Laser ablation coupled to MC-ICP-MS is now regarded as one of the tools of the trade for many geochemical applications involving the measurement of isotope ratios. Vroon et al. ${ }^{378}$ reviewed the problems encountered in the measurement of $\mathrm{Sr}$ isotope ratios in geological materials by LA-MC-ICP-MS. The most important isobaric interferences are from $\mathrm{Kr}$ and $\mathrm{Rb}$, whereas calcium dimers and argides and doubly charged REEs are significant only when sampling minerals that contain substantial amounts of these elements. Successful corrections for Rb isomers appear to be limited to minerals with $\mathrm{Rb} / \mathrm{Sr}$ ratios less than 0.05 . The authors concluded that an improvement in the way that the $\mathrm{Rb}$ correction on ${ }^{87} \mathrm{Sr}$ is performed is required for minerals with high $\mathrm{Rb} / \mathrm{Sr}$ contents, such as mica and biotite. Paton et al. ${ }^{379}$ demonstrated the efficacy of LA-MC-ICP-MS for measuring $\mathrm{Sr}$ isotope ratios accurately and precisely in kimberlites and related rocks, negating the need for timeconsuming mineral separation procedures. After applying corrections for $\mathrm{Kr}^{+}, \mathrm{Rb}^{+}$, $\mathrm{Er}^{2+}$ and $\mathrm{Yb}^{2+}$, as well as instrumental bias, the $\mathrm{Sr}$ isotope ratios from in situ measurements were much more tightly constrained than data from bulk analysis, which can be affected by contamination and alteration effects. For these materials 
with low $\mathrm{Rb} / \mathrm{Sr}$ contents, it was demonstrated that interferences from $\mathrm{Ca}$ dimers and argides did not affect the quality of the data significantly. Yang and coworkers 380 showed how they mitigated the effects of interferences from $\mathrm{Ce}$ and $\mathrm{Sm}$ when determining $\mathrm{Nd}$ ratios in minerals with relatively high $\mathrm{Nd}$ contents, such as apatite, titanite, monazite and perovskite. Souders and Sylvester ${ }^{381}$ developed an analytical protocol for LA-MC-ICP-MS using an array of Channeltron ion counters that enabled them to measure $\mathrm{Pb}$ isotope ratios, including those relative to ${ }^{204} \mathrm{~Pb}$, for silicate glasses with total $\mathrm{Pb}$ contents between 1 and $11 \mu \mathrm{g} \mathrm{g}^{-1}$. Spot sizes as small as 40-69 $\mu \mathrm{m}$ provided better spatial resolution and quantification limits than previous studies reporting ${ }^{204} \mathrm{~Pb}$ data by this technique, whilst retaining similar levels of accuracy and precision. Other applications are included in a review of papers on the analysis of geochemical and cosmochemical materials published between October 2004 and September $2006^{382}$.

Multicollector ICP-MS with laser sampling is now regarded as a rapid, accurate and relatively inexpensive way of making in situ measurements for $\mathrm{U}-\mathrm{Pb}$ dating. Developments in instrumentation and experimental methodology now make it possible to generate $\mathrm{U}-\mathrm{Pb}$ ages with an accuracy of better than $1 \%$ for most zircon standards $^{383}$. By connecting quadrupole ICP-MS and MC-ICP-MS instruments to an excimer LA system, Yuan et al. ${ }^{384}$ demonstrated the feasibility of reporting simultaneous measurements of $\mathrm{U}-\mathrm{Pb}$ age, $\mathrm{Hf}$ isotopes and trace elements compositions from a single spot in zircon. They obtained $\mathrm{U}-\mathrm{Pb}$ ages and $\mathrm{Hf}$ isotopic compositions for six standard zircons that agreed with recommended values or those reported in previous studies. This approach is potentially useful when dealing with small zircons and those with complicated zoning. Paquette and Tiepolo ${ }^{385}$ showed that a $193 \mathrm{~nm}$ excimer laser coupled to a single collector SF-ICP-MS instrument was capable of providing high quality $\mathrm{U}-\mathrm{Th}-\mathrm{Pb}$ geochronological data in grains of monazite. Spot diameters as small as $5 \mu \mathrm{m}$ were employed to date domains in Palaeozoic to Precambrian monazites, whereas $25 \mu \mathrm{m}$ diameter craters were required for the analysis of some Miocene hydrothermal monazites. Measurements of $\mathrm{U}-\mathrm{Pb}$ ages in uranium oxide minerals by LA SF-ICP-MS have also been reported recently $^{386}$.

The ability to obtain rapid in situ high precision measurements of ${ }^{187} \mathrm{Os} /{ }^{188} \mathrm{Os}$ and ${ }^{186} \mathrm{Os} /{ }^{188} \mathrm{Os}$ ratios in platinum group alloy grains by LA-MC-ICP-MS has been demonstrated by Nowell and coworkers ${ }^{387}$. Because of isobaric interferences from Pt, 
${ }^{189} \mathrm{Os} /{ }^{188}$ Os was used to correct for instrumental mass bias. Although corrections were applied for isobaric interferences from Re and $\mathrm{W}$ on the Os mass spectrum, they demonstrated that accurate correction for Re is problematical when the ${ }^{187} \mathrm{Re} /{ }^{188} \mathrm{Os}$ ratio is greater than about 0.5 .

Laser ablation ICP-MS is only one of several methods, such as EPMA, PIXE, SIMS and synchrotron XRF, capable of producing two and three dimensional images of elemental and isotopic variations on the scale of micrometers. Woodhead and colleagues $^{388}$ discuss why LA-ICP-MS has not been developed to the same level as other techniques for the imaging of geological materials. For this type of application, ablation cell designs would need to be optimised for a rapid washout, in contrast to the signal smoothing often preferred for single spot analysis. They argue that if care is taken to minimise the problem of resampling material removed by previous laser pulses, and appropriate data processing software is developed, then LA-ICP-MS imaging should have a promising future.

\subsubsection{Laser-induced breakdown spectroscopy}

One of the established uses of LIBS is for quality control in industrial processing. As there are many variables that are likely to perturb the LIBS signal, it is important to understand the dominant factors for any particular application. In the analysis of iron ore slurries, the influence of particle size and mineral phase (magnetite or hematite) was studied ${ }^{389}$. By applying corrections to model the linear decrease in $\mathrm{Fe}$ intensities as a function of magnetite content and increase in LIBS signal with particle fineness, fit-for-purpose measurements of $\mathrm{Fe}$ and $\mathrm{Si}$ in the ores were obtained. A major drawback of LIBS for on-line mineral analysis on moving conveyer belts is that it analyses only the surface concentrations, whereas it is important to know the impurities in the whole rock. However, Gaft et al. ${ }^{390}$ demonstrated that, for phosphates and coal, the surface analysed by LIBS is representative of the entire volume, and the on-line data are well correlated with control analyses obtained by XRF and prompt gamma NAA. Silicate raw materials for the manufacture of bricks, tiles and stoneware were analysed by LIBS using single and double pulse techniques ${ }^{391}$. The double pulse mode provided higher sensitivity and yielded LODs that were ten times lower for Si and Mg compared to single pulse. A pilot study explored the capability of LIBS to identify carbonate and silicate minerals rapidly and accurately ${ }^{392}$. Correct identification relied on having a 
representative sample in the database. Although the approach appeared promising, because LIBS provides compositional and not stoichiometric information, it sometimes resulted in a mineral being misidentified as a member of a different mineral family. Laville and colleagues ${ }^{393}$ describe how, during glass production, they applied LIBS to the multi-elemental analysis of mineral melts containing several oxides present in various concentrations. Because no sufficiently linear trends could be extracted from the calibration curves for the elements of interest, a second order polynomial linear multivariate inverse regression was used for quantitative analysis.

Another common application of LIBS is sampling and analysis in remote locations, including outer space. Thus LIBS will be used to identify rocks on the surface of Mars ${ }^{394}$. Three chemometric methods of treating the LIBS spectra were compared to see which model was the most robust for classifying unknown rocks by remote LIBS; a combination of two approaches was the most promising. Experiments have also been conducted to assess the constraints on the use of LIBS at the subzero temperatures and 7 mbar atmospheric pressure typical of conditions on the surface of $\operatorname{Mars}^{303}$. At pressures above 6 mbar, in a $\mathrm{CO}_{2}$ atmosphere, the LIBS signal from soils and rocks containing structural or surface moisture was strongly temperature dependent. The results suggested that LIBS analysis under Martian conditions should not be attempted at temperatures close to those of the known phase transitions of water and ice, i.e. around $0{ }^{\circ} \mathrm{C},-40{ }^{\circ} \mathrm{C}$ and $-50{ }^{\circ} \mathrm{C}$. More work is required to ascertain the influence of pore size distribution, surface roughness, degree of moisture and pore filling on quantitative measurements. Feasibility studies have been carried out to see whether LIBS can be used to determine the composition of a meteorite by analysis of the plasma emission spectrum generated when a meteorite meets the Earth's atmosphere $^{395}$. The practicality of this application remains unclear.

\subsubsection{Slurry sampling}

The introduction of solid samples as slurries still has a few practitioners in some corners of the world, especially Brazil it would seem. Various chemical matrix modifiers have been used in methods based on slurry sampling, such as those developed for measuring $\mathrm{Mn}$ and $\mathrm{Ni}$ in lake and marine sediments ${ }^{396}$ and $\mathrm{Sb}$ in marine sediments ${ }^{397}$ by GF-AAS, and As, Cd, Pb and Tl in coal by ETV-ICP-MS ${ }^{398}$. In other studies involving slurries, $\mathrm{Hg}$ was determined in geological samples by CV-AAS ${ }^{399}$ and As in sediments by HG-AAS ${ }^{400}$, but it is difficult to perceive much that is novel. 


\subsection{Sample Treatment}

\subsubsection{Sample dissolution}

Although there is continued interest in the use of microwave digestion techniques to promote sample dissolution, the limitations of this technique need to be appreciated, particularly for geological materials. Navarro et al. ${ }^{401}$ described the tests they performed using a $\mathrm{HF}-\mathrm{HNO}_{3}$ attack on nine basaltic RMs, and compared the results obtained from digestion in a microwave oven with those from Teflon Parr bombs. Although the data demonstrated that complete dissolution of the basalts was achieved using the more rapid microwave method, it is important to recognise that this protocol would not necessarily be so successful in dissolving rocks with a higher silica content and resistate minerals. Thus, a more appropriate application is on-line microwave-assisted continuous leaching of soils with water and various strengths of nitric acid, coupled to ICP-MS, for screening samples for geochemical exploration ${ }^{402}$. Microwave-induced combustion (MIC) is particularly suitable for the decomposition of coal and other organic-rich matrices. A review ${ }^{403}$ of the main characteristics and drawbacks of closed vessel combustion techniques including bomb combustion, oxygen flask and MIC is available. The MIC protocol described for coal digestion prior to the determination of halogens would probably require a sympathetic Health and Safety Advisor for its implementation!

Silicon is normally removed as gaseous $\mathrm{SiF}_{4}$ during HF-based acid digestions of silicate rocks. However, other volatile elements, such as $\mathrm{As}, \mathrm{Hg}$ and $\mathrm{Se}$, may also be lost during this process. In an alternative approach for samples containing high levels of sodium and silica, matrix elements were precipitated as sodium fluorosilicate by adding $\mathrm{NaCl}$ solution to highly acidic digests ${ }^{244}$. Trace elements were then backextracted into a mixture of methanol and nitric acid. This procedure was shown to be suitable for the determination of 14 trace elements in NIST soil and sediment CRMs by ICP-MS. Because $\mathrm{Ca}$ and $\mathrm{Mg}$ also coprecipitated with the $\mathrm{Na}_{2} \mathrm{SiF}_{6}$ to a large degree, the method had the potential for removing major elements from saline solutions, such as seawater, thus alleviating some matrix effects in ICP-MS.

A review by Bacon and Davidson ${ }^{14}$ (547 refs) is recommended to anyone with an interest in sequential extraction procedures. Although they consider that sequential extractions have a healthy future, particularly for environmental monitoring, they 
stress that studies are more likely to be successful if a recognised scheme, such as the revised BCR procedure, is adopted and the specified protocol is strictly adhered to. However, it is doubtful whether this will come to pass. Arain and colleagues ${ }^{251}$, being keen to reduce the time taken to produce the extractions, compared data obtained for $\mathrm{Cd}, \mathrm{Cr}, \mathrm{Cu}, \mathrm{Ni}, \mathrm{Pb}$ and $\mathrm{Zn}$ in lake sediments by the standard BCR procedure with those from ultrasonic-assisted, microwave-induced and conventional single extractions. Through the use of the BCR CRM 701, they reckoned that the variances associated with the results from their time-saving protocols were statistically equivalent to those obtained by the conventional but lengthier BCR procedures. Data from five widely-used two-hour single extraction methods were compared to assess the availability of $\mathrm{As}$ and $\mathrm{Sb}$ in soils and sediments ${ }^{404}$. Simple deionised water and 0.1 $\mathrm{M} \mathrm{Na}_{2} \mathrm{HPO}_{4}$ extractions were preferred for quick estimates of easily-exchangeable and specifically-sorbed $\mathrm{Sb}$ respectively.

\subsubsection{Separation and preconcentration}

The platinum group elements (PGEs) and Re can provide insights into petrogenetic processes and the evolution of the Earth, but their determination in geological samples is difficult because of their low abundance and heterogeneous distributions. Of the various techniques that have been employed, the Carius tube method has been shown to be efficient in dissolving refractory PGE minerals; total procedural blanks are usually low because small volumes of reagents in a sealed glass tube are used. In order to increase the mass of sample and reduce the potential hazard posed by the high internal pressure generated, Qi et al. ${ }^{405}$ placed the Carius tube in a sealed stainless steel high-pressure autoclave filled with water to balance the internal pressure. This approach allowed them to digest up to $12 \mathrm{~g}$ of mafic material and $2 \mathrm{~g}$ of chromite at $330^{\circ} \mathrm{C}$ in $12 \mathrm{~h}$, after the addition of an appropriate amount of enriched isotope spike solution containing ${ }^{193} \mathrm{Ir},{ }^{190} \mathrm{Os},{ }^{105} \mathrm{Pd},{ }^{194} \mathrm{Pt},{ }^{185} \mathrm{Re}$ and ${ }^{101} \mathrm{Ru}$. Osmium was distilled from the aqua regia solution generated and then the PGEs and Re separated from the matrix using AG1-X8 anion exchange resin prior to measurement by ICP-MS. It is interesting to compare this approach with that of Shinotsuka and Suzuki $^{406}$, who also carried out a Carius tube digestion followed by ID-ICP-MS to determine the same suite of elements in a selection of rock CRMs. After Os distillation they employed cation exchange separation on AG50W-X8 columns, and 
solvent extraction using N-benzoyl-N-phenylhydroxylamine in chloroform, to overcome spectral interferences from impurities retained in the PGE fraction after separation. Because of their widespread use in catalytic converters, there is increasing emphasis on the measurement of PGEs in a variety of environmental matrices. Sensitive methods are required for their quantification; Dubiella-Jackoska and colleagues have reviewed the options available ${ }^{10}$. A simple procedure involving cloud point extraction has been described for the preconcentration and separation of $\mathrm{Au}, \mathrm{Pd}$ and $\mathrm{Pt}$ in geological and environmental samples ${ }^{312}$. The method is based on the formation of hydrophobic complexes of $\mathrm{Au}, \mathrm{Pd}$ and $\mathrm{Pt}$ with N,N-dihexyl-N'benzoylthiourea in an $\mathrm{HCl}$ medium, followed by their extraction in a small volume of Triton X-114, a non-ionic surfactant. After washing, the viscosity of surfactant-rich phase was reduced by dissolution in methanol containing $1 \mathrm{~mol} \mathrm{~L}^{-1} \mathrm{HNO}_{3}$ and the PGEs determined by ICP-MS after the addition of an internal standard. The accuracy of the procedure was assessed using CRMs BCR 723, Road dust, and NIST SRM 2709, San Joaquin soil.

Continuing interest in methods for the determination of gold and silver in geological materials reflects their economic importance. Various techniques have been developed to separate and preconcentrate these metals prior to measurement by FAAS. These include: the use of a microcolumn packed with nanoparticles of $\mathrm{TiO}_{2}$ immobilised on silica gel for gold in ores and soils ${ }^{407}$; a macroporous and non-ionic resin, Amberlite XAD-16, as a solid sorbent and N,N-diethyl-N'-benzoylthiourea as a chelating agent for silver in copper ores ${ }^{408}$; and the use of chitin in a weakly acidic medium to preconcentrate $\mathrm{Ag}, \mathrm{Au}$ and $\mathrm{Pd}$ from silicate rocks ${ }^{409}$. Shamsipur and Ramezania ${ }^{410}$ proposed a scheme to measure $\mathrm{Au}$ in silicate ore samples by ETAAS after dispersive liquid-liquid microextraction. In this method, $\mathrm{Au}$ is complexed with Victoria Blue $\mathrm{R}$ and extracted into fine droplets of chlorobenzene, before the addition of palladium nitrate as a chemical modifier. A Chinese group explored the possibility of using carbon nanofibres as a novel adsorption material for the preconcentration of $\mathrm{Au}$ and Pd prior to ICP-MS ${ }^{411,412}$. The proposed method was validated by the analysis of two geological RMs containing 1-5 $\mathrm{ng} \mathrm{g}^{-1} \mathrm{Au}$ and 4-60 $\mathrm{ng} \mathrm{g}^{-1} \mathrm{Pd}$.

Three sample preparation protocols were evaluated for the determination of ${ }^{226} \mathrm{Ra}$ in lake sediments by $S F-I C P-M S^{413}$. All samples analysed were spiked with ${ }^{228} \mathrm{Ra}$ in order to assess ${ }^{226} \mathrm{Ra}$ recovery throughout the digestion and separation processes. Potential polyatomic interferences were investigated to establish the level 
of sample purification required. A combination of ion-exchange and extraction chromatography was most effective at preconcentrating ${ }^{226} \mathrm{Ra}$ but the yields were variable, whereas the protocol involving an initial coprecipitation of $\mathrm{Ba}$ and $\mathrm{Ra}$ onto manganese dioxide provided lower but more reproducible recoveries.

\subsubsection{Speciation studies}

Although organotin-based antifouling paints are no longer used in the marine environment in many parts of the world, there is still a requirement to monitor the levels of organotin species in marine sediments. Information on environmental levels, toxicity and human exposure to TBT, plus methods for their determination, are given in a recent review $(212 \mathrm{refs})^{414}$. Extraction of organotin compounds from the solid material is a critical step and can be one of the major sources of error. For this reason, a comprehensive summary of current trends in extraction techniques for Sn and As species will provide a good starting point for newcomers to this field ${ }^{415}$. Three polar solvents (acetic acid, a 3+1 mixture of acetic acid and methanol, and $1+1+1$ mixture of acetic acid, methanol and water) combined with three different modes of extraction (mechanical shaking, ultrasonic and microwave-assisted) were assessed for the determination of butyltins in sediments by GC-MS ${ }^{416}$. It was concluded that a $30 \mathrm{~min}$ ultrasonic extraction at $50{ }^{\circ} \mathrm{C}$ with $100 \%$ acetic acid provided quantitative recoveries and was simpler than the microwave-assisted procedure. The novelty of the method reported by Carvalho et al. ${ }^{417}$ was the combination of headspace solid phase microextraction (SPME) with GC-MS upgraded by the introduction of tandem MS. Butyltins were extracted with a $1+1$ mixture of $6 \mathrm{M} \mathrm{HCl}$ and ethanol from $0.5 \mathrm{~g}$ of sediment in a ultrasonic bath before headspace SPME was performed on a $50 \mu \mathrm{L}$ aliquot of extract. Through the use of tandem MS, LODs of $0.3 \mathrm{ng} \mathrm{g}^{-1}$ MBT, $0.3 \mathrm{ng} \mathrm{g}^{-1}$ DBT and $0.4 \mathrm{ng} \mathrm{g}^{-1} \mathrm{TBT}$ in the original sample were obtained. Pressurised liquid extraction is another technique that is finding favour for this application because it produces cleaner extracts than other classical extraction procedures. Its effectiveness for the measurement of TBT in sediments by GC-IDMS was demonstrated and a LOD of $1.5 \mathrm{ng} \mathrm{g}^{-1}$ as $\mathrm{Sn}$ was reported ${ }^{418}$. In recent years there has been a growth in the use of GC-ICP-MS for the determination of organotin species because it provides the sensitivity that few other techniques can offer and allows simultaneous multi-isotopic spiking for ID procedures. A Hungarian group report the detailed optimisation of their GC-ICP-MS system for such analysis ${ }^{419}$. They used $1 \%$ xenon in argon to tune the 
instrument and obtained LODs of 5.6, 6.6 and $3.4 \mathrm{ng} \mathrm{Sn} \mathrm{kg}^{-1}$ for MBT, DBT and TBT respectively. Four different numerical approaches to multiple spiking strategies have been examined critically in relation to the analysis of DBT and TBT in the NRCC marine sediment CRM SOPH- ${ }^{420}$. It is somewhat reassuring to find that all the published methodologies for the determination of multiple species by ID were found to provide identical concentrations of the endogenous species; however, some methods were much more complex than others and some more easily extended to cover more than two species.

As noted in last year's Update ${ }^{1}$, the quantitative extraction of $\mathrm{Hg}$ species from sediments while minimising any potential transformations, continues to be of concern. Nevado et $a .^{421}$ devised a strategy for the extraction of MMHg based on closed-vessel microwave-assisted heating with $6 \mathrm{M} \mathrm{HNO}_{3}$. Solvent extraction with dichloromethane was used to clean up sediments with high levels of $\mathrm{Hg}\left(>500 \mathrm{ng} \mathrm{g}^{-1}\right)$ prior to measurement of ethylated derivatives by capillary GC-AFS. Samples with low $\mathrm{Hg}$ contents were preconcentrated under nitrogen at room temperature. Recent advances in the use of enriched isotope tracers in the measurement of $\mathrm{Hg}$ species and studies of biogeochemical processes have been discussed ${ }^{422}$.

\subsection{Instrumental analysis}

\subsubsection{Atomic absorption spectrometry}

As indicated in Section 4.3.2, there is still a demand for relatively inexpensive methods for the determination of $\mathrm{Ag}$ and $\mathrm{Au}$ in geological materials based on flame AAS after separation and preconcentration ${ }^{407-409}$. A novel displacement cloud point extraction approach has been developed for the determination of trace amounts of $\mathrm{Ag}$ in silicate matrices by thermospray flame furnace $\mathrm{AAS}^{272}$. It involves two cloud point extractions. Firstly, a solution of copper, DDTC and Triton X-114 surfactant are heated at $40{ }^{\circ} \mathrm{C}$ for $10 \mathrm{~min}$ to form Cu-DDTC; the surfactant-rich phase containing the $\mathrm{Cu}$-DDTC complex is then separated from the aqueous phase and used to extract $\mathrm{Ag}$ from the test material. Because the stability of Ag-DDTC is greater than that of $\mathrm{Cu}$ DDTC, $\mathrm{Ag}^{+}$displaces $\mathrm{Cu}^{2+}$ from the $\mathrm{Cu}$-DDTC complex, thus achieving separation and preconcentration of $\mathrm{Ag}$ from sample matrices. Potential interferences from other transition metal ions are largely eliminated because their DDTC complexes have a lower stability than that of $\mathrm{Cu}$-DDTC and therefore they cannot displace copper from 
the complex. The method was successfully applied to soil, marine sediment and silver ore CRMs.

Readers interested in direct solid sample analysis by ET-AAS are advised to read the review (75 refs) by Welz et al. ${ }^{423}$. The authors were somewhat surprised to find that the large majority of papers on direct solid sample introduction ET-AAS published over the last 10 to 15 years reported the use of aqueous standards for calibration, even for complex matrices. This confirmed that with careful method development and programme optimisation, matrix effects could be eliminated in many applications. However, the background correction systems available for line source AAS were not able to handle the spectral interferences in all cases. In contrast, high resolution continuum source ET-AAS offers superior background correction capabilities, making it an attractive alternative to slurry introduction for samples that are difficult to dissolve.

\subsubsection{Atomic emission spectrometry}

Although ICP-AES is routinely used for geochemical analysis, novel developments in this area are sparse. Rabb and Olesik ${ }^{424}$ compared three approaches for obtaining high precision concentration data in complex matrices by ICP-AES with a target uncertainty of less than $0.2 \%$. Three rock CRMs from the USGS and a NIST river sediment were analysed for $\mathrm{Ba}, \mathrm{Cr}, \mathrm{Cu}, \mathrm{Mn}, \mathrm{Ni}, \mathrm{V}$ and $\mathrm{Zn}$ during this assessment. Care was taken to ensure counting statistics did not limit the measurement uncertainties, gravimetric rather than volumetric methods were employed when handling the standards and sample solutions, and a function fitted to the data to account for short term drift. They demonstrated that this basic approach, combined with the Common Analyte Internal Standard (CAIS) method or standard addition calibration had the potential to achieve relative uncertainties of $0.1-0.2 \%$. However, the CAIS matrix correction method, based on a ratio of emission intensities from high and low energy lines (Mn II 257/Mn I $403 \mathrm{~nm}$ ), was not sufficient to reduce all matrix-induced errors to below $0.2 \%$ in these materials. It is instructive to note that the preparation of samples and standards appeared to be more challenging than obtaining very high precision instrumental measurements. 


\subsubsection{Inductively coupled plasma mass spectrometry}

Inductively coupled plasma mass spectrometry, in all its forms, has become the preferred technique for many geochemical applications. This year it is noticeable that the reporting of developments involving quadrupole instruments has decreased markedly, with the literature dominated by the measurement of isotope ratios by MCICP-MS.

A couple of recent studies concerning elemental analysis are worthy of comment. Since Mn, Re and Tc are members of group 7A in the periodic table, the Re content of manganese nodules was investigated as a proxy for ${ }^{99} \mathrm{Tc}^{425}$. An alkaline fusion was performed on powdered Mn nodule after spiking with ${ }^{185} \operatorname{Re}$ and the resulting solution passed through pre-treated TEVA resin to separate the Re from Os isobars and the majority of the sample matrix; this yielded a LOD of $4.5 \mathrm{ng} \mathrm{kg}^{-1}$. The nodules studied were found to be depleted in Re relative to crustal abundances, showing that Re had not accumulated in the samples. A method for determining REEs in ultramafic rocks at sub-ng $\mathrm{g}^{-1}$ levels by quadrupole ICP-MS without preconcentration has been reported ${ }^{426}$. By incorporating a new method of correcting for interferences from $\mathrm{BaO}$ and $\mathrm{BaOH}$ on $\mathrm{Eu}$, LODs of 0.01 to $0.08 \mathrm{ng} \mathrm{g}^{-1}$ and reproducibilities of 3-6\% were achieved with demonstrable accuracy.

Electrothermal vaporization coupled to ICP-MS has been employed for some specialist applications. A novel approach to the separation of the ${ }^{87} \mathrm{Rb}$ and ${ }^{87} \mathrm{Sr}$ isobars utilised the thermal ramp of an ETV to separate the more volatile $\mathrm{Rb}$ from $\mathrm{Sr}$, allowing the measurement of both isotopes without chromatographic separation ${ }^{427}$. One-step and two-step vaporization protocols were devised in conjunction with TOF ICP-MS, and the final two-step method was tested on a potassium feldspar standard using MC-ICP-MS for the isotope ratio measurements. An advantage of this technique is that very small quantities of material can be analysed, but a systematic bias of approximately $10 \%$ of unknown origin, together with a precision of $0.3 \%$ RSD, means that currently it could only serve as a screening tool. Thermal programming was also used to separate interferences from yttrium and zirconium during the measurement of ${ }^{90} \mathrm{Sr}$ by ETV in combination with DRC technology ${ }^{428}$. Sediment samples were dissolved using a $3+3+1$ mixture of $\mathrm{HF}, \mathrm{HNO}_{3}$ and $\mathrm{HClO}_{4}$ and the Sr separated on a Sr-specific Eichrom resin. A procedural LOD of $3.5 \mathrm{pg} \mathrm{g}^{-1}$ and recoveries of $97-102 \%$ for ${ }^{90} \mathrm{Sr}$ were obtained from spiking NRCC CRM MESS3, Marine sediment. Ammonium hydroxide was employed as a matrix modifier for the 
determination of ${ }^{99} \mathrm{Tc}$ in a variety of environmental materials by ETV-ICP-MS ${ }^{429}$. After radiochemical separation, addition of excess $\mathrm{NH}_{4} \mathrm{OH}$ resulted in a stable ${ }^{99} \mathrm{Tc}$ signal, reduced memory effects, better reproducibility and improved LODs.

Isotope dilution has been used in the measurement of trace concentrations of $\mathrm{Hg}$ in sediment cores by SF-ICP-MS ${ }^{430}$. Particular attention was paid to the method of mass bias correction applied after the addition of an enriched ${ }^{201} \mathrm{Hg}$ spike at the digestion step. Results obtained using a ${ }^{202} \mathrm{Hg} /{ }^{201} \mathrm{Hg}$ external mass bias correction were compared with those from an internal mass bias correction method based on an average of ${ }^{200} \mathrm{Hg} /{ }^{201} \mathrm{Hg}$ and ${ }^{202} \mathrm{Hg} /{ }^{201} \mathrm{Hg}$. The two sets of data were not statistically different but the internal calibration protocol was better at compensating for any drift in mass bias. The procedural LOD was estimated to be $12 \mathrm{ng} \mathrm{g}^{-1}$, which was sufficiently low for successful analysis of sediment core from Lake Como, Italy, where the $\mathrm{Hg}$ concentrations ranged from 66 to $750 \mathrm{ng} \mathrm{g}^{-1}$.

When MC-ICP-MS was first developed about 15 years ago, it opened up the possibility of measuring the isotope ratios of light elements $(\mathrm{m} / \mathrm{z}<80)$ with sufficient precision to detect subtle changes in their composition in geological samples. The improvements in second-generation instruments that realised this potential, and methods for obtaining high precision measurements for $\mathrm{Ca}, \mathrm{Cu}, \mathrm{Li}$ and $\mathrm{Mg}$ isotopes, have been reviewed ( $85 \mathrm{refs})^{431}$. This complements an up to date review (71 refs) of research into $\mathrm{Zn}$ isotope systems in biogeochemistry ${ }^{432}$. Several critical issues in the measurement of $\mathrm{Cu}$ and $\mathrm{Zn}$ isotope ratios in estuarine particulate materials were addressed by Petit et $a l .^{433}$. Sample-standard bracketing and empirical external normalisation methods of mass bias correction provided long-term precisions of 0.06 and $0.07 \%$ (2SD) respectively. The most significant interferences were from $\mathrm{Ti}$ and Cr oxides, which produced a bias of $-5.1 \%$ and $+0.60 \%$ respectively on $\delta^{68} \mathrm{Zn} /{ }^{64} \mathrm{Zn}$. Rosner and coworkers ${ }^{434}$ developed a new approach to fast and accurate Li isotope ratio measurements in silicate rocks by MC-ICP-MS. In contrast to most other published methods, they did not use a desolvating system and consequently were less affected by matrix-induced shifts in the instrumental mass bias. The samples were dissolved in $1 \mathrm{~mol} \mathrm{~L}^{-1} \mathrm{HNO}_{3}$ in $80 \% \mathrm{v} / \mathrm{v}$ methanol, and $\mathrm{Li}$ was separated from most other relevant elements by ion chromatography. The absence of a nitric acid rinse step between the samples and the bracketing calibrators increased the sample throughput by a factor of two, and allowed accurate tracking of the instrumental mass bias. The overall analytical uncertainty was typically $0.5 \%$ ( $2 \mathrm{~s})$. The accurate and precise 
measurement of Se isotopes is a difficult task as this element is often present at low concentrations and suffers from a number of significant isobaric and polyatomic interferences in its determination by HG-MC-ICP-MS. Elwaer and Hintermann ${ }^{435}$ achieved selective preconcentration and separation of Se from lake sediments using columns packed with thiol cellulose powder (TCP). Selenium was quantitatively retained on $0.1 \mathrm{~g}$ of TCP, while hydride-forming elements, such as As and Ge, and transition metals $\left(\mathrm{Co}, \mathrm{Cu}, \mathrm{Fe}\right.$ and $\mathrm{Ni}$ ) passed through the column. $\mathrm{A}{ }^{74} \mathrm{Se} /{ }^{77} \mathrm{Se}$ double spike was used to correct for isotope fractionation during sample purification and for instrumental mass bias; long-term precision of $0.15-0.21 \%$ was reported.

Many of the developments in the measurement of isotope ratios by MC-ICPMS are aimed at simplifying methods of separating the isotopes of interest from potential interferences. Galler et al. ${ }^{436}$ modified a manual solid-phase extraction procedure involving an $\mathrm{Sr}$-specific resin to separate $\mathrm{Sr}$ from $\mathrm{Rb}$ for use on-line via $\mathrm{FI}$ technology prior to the determination of ${ }^{87} \mathrm{Sr} /{ }^{86} \mathrm{Sr}$. They overcame the significant memory effects that this resin is known to exhibit by employing an efficient elution strategy; this allowed it to be reused in the FI system for up to 40 samples. Measured ${ }^{87} \mathrm{Sr} /{ }^{86} \mathrm{Sr}$ ratios for five basalts were in excellent agreement with published data and synthetic samples with $\mathrm{Rb} / \mathrm{Sr}$ ratios of up to 10:1 could be measured without significant interferences from ${ }^{87} \mathrm{Rb}$. A one-step anionic exchange procedure was developed to separate $\mathrm{Cd}$ and $\mathrm{Pb}$ simultaneously for the accurate determination of the $\mathrm{Cd}$ and $\mathrm{Pb}$ isotopic composition of sediments by MC-ICP-MS and TIMS respectively ${ }^{437}$. After digestion, the resulting $2 \mathrm{ml}$ sample in $2 \mathrm{~mol} \mathrm{~L}^{-1} \mathrm{HCl}$ was loaded onto AG-MP-1M macroporous resin (from Bio-Rad) and treated with progressively weaker solutions of $\mathrm{HCl}$; the $\mathrm{Pb}$ fraction was eluted with $0.3 \mathrm{M} \mathrm{HCl}$, while $\mathrm{Cd}$ was finally eluted in $0.0012 \mathrm{M} \mathrm{HCl}$. The ${ }^{138} \mathrm{Ce} /{ }^{142} \mathrm{Ce}$ ratio is used as a geochemical tracer but again selective chemical separation is required for accurate measurements by MCICP-MS because other REEs and barium interfere with the analysis. Tazoe and coworkers $^{150}$ devised an extraction procedure, using the chelating Ln resin from Eichrom, in which $\mathrm{Ce}$ is oxidised from $\mathrm{Ce}^{\mathrm{III}}$ to $\mathrm{Ce}^{\mathrm{IV}}$ with $\mathrm{KBO}_{3}$ in nitric acid, allowing Ce to be separated easily from the other REEs and barium.

Multi-collector ICP-MS offers two main advantages over TIMS for the measurement of Mo isotope ratios: Mo is more easily ionised in the ICP and a more rapid throughput of samples is possible. For both techniques, however, Mo has to be separated from the accompanying matrix elements to eliminate spectral interferences. 
Malinovskii et al. ${ }^{438}$ achieved this by ion exchange chromatography on Chelex-100 (200-400 mesh). Some sediment samples still contained too much iron after the first pass; in such cases, the $6 \mathrm{M} \mathrm{NH}_{4} \mathrm{OH}$ solution containing the Mo was evaporated, dissolved in $0.3 \mathrm{M} \mathrm{HNO}_{3}$ and reloaded onto the same column after reconditioning. They corrected for mass bias using standard-sample bracketing with the addition of Pd as an internal standard. However, Pietruszka and Reznik ${ }^{439}$ demonstrated a matrix effect arising indirectly from chemical separation and purification of Mo. They used Eichrom AG1-X8 anion exchange resin, which was preferred over one from Bio-Rad because it had a significantly lower Mo blank. The effect appeared to be caused by organic material stripped from the resin. All their attempts to control this problem failed and they were forced to conclude that the double spike method of adding two enriched Mo isotopes to correct for mass bias, despite the potential complications of memory effects, might be the only solution.

In a two-part exposition, the potential of MC-ICP-MS to provide high precision measurements of the isotope ratios of osmium by $\mathrm{LA}^{387}$ and in solutionmode $^{440}$ has been investigated. A new method for establishing appropriate interference corrections was proposed and evaluated by analysing solutions with widely varying ratios of interfering element and analyte. By keeping the Os in a reduced or complexed state, and ensuring that the sample introduction system was not allowed to dry in air, Os washout and memory effects were no worse than for elements such as $\mathrm{Sr}$ and $\mathrm{Pb}$.

Cold vapour generation is the most common means of introducing samples into MC-ICP-MS for determining $\mathrm{Hg}$ isotope ratios because it offers the advantages of high sensitivity and separation of the analyte from the matrix. However, it has been shown that $\mathrm{Hg}$ isotope fractionation can occur during the reduction from $\mathrm{Hg}^{2+}$ to $\mathrm{Hg}^{0}$. Recently, an approach based on solution nebulisation has been reported ${ }^{441}$. Anionexchange on Dowex 1-X8 resin provided separation from the concomitant matrix and a solution of $0.15 \%$ L-cysteine in $0.06 \mathrm{M} \mathrm{HCl}$ was found to be the most convenient eluent for the subsequent measurements by MC-ICP-MS. No significant memory effects were observed using a mixture of $0.12 \mathrm{M} \mathrm{HCl}$ and $0.002 \mathrm{M} \mathrm{HBr}$ as matrix and wash solution. Instrumental mass bias was corrected by the bracketing standards approach and normalisation to ${ }^{205} \mathrm{Tl} /{ }^{203} \mathrm{Tl}$. Four different $\mathrm{Hg}$ isotope ratios were determined in sediment samples with an external reproducibility of $0.06-0.18 \%$ o $(2 \sigma)$ for complete procedural replicates. 
For environmental studies, quadrupole ICP-MS can provide $\mathrm{Pb}$ isotope ratio data that are fit for purpose provided appropriate corrections are applied to compensate for mass bias as well the presence of mercury. Thus for survey-type applications, such as fingerprinting mining waste derived from galena ores ${ }^{291}$, RSDs of $0.11-0.27 \%$ were sufficient to identify the source of the material. Thallium was used as an internal standard in this study and that of Chernyshev et al. ${ }^{442}$ in their high precision measurements of $\mathrm{Pb}$ isotopes in ores and rocks by MC-ICP-MS. Continuous leach ICP-MS has been developed to generate information on the release of trace elements during the breakdown of minerals. This approach has been extended to the measurement of $\mathrm{Pb}$ isotope ratios by SF-ICP-MS ${ }^{443}$. These ratios were compared to the release patterns of other elements such as $\mathrm{U}$, Th and total $\mathrm{Pb}$, to investigate isotopically distinct $\mathrm{Pb}$ reservoirs within geological and environmental samples.

Results from a recent interlaboratory comparison, the Regular European Interlaboratory Measurement Evaluation Programme (REIMEP)-18, demonstrated that accurate results for $\mathrm{U}$ isotope ratios are not currently achieved by all facilities using MC-ICP-MS. Against this background, it is pertinent to note that several procedures for the measurement of Th and $U$ isotopes in geological materials by MC-ICP-MS have been published recently ${ }^{444-446}$. All applied the standard-sample bracketing method to correct for instrumental mass bias and emphasized that $U$ standards should not be used to correct Th measurements, and vice versa, because of differences between gain and mass discrimination factors between the two elements. Laboratories relied on the calibration of their in-house Th standards by TIMS because of the paucity of well characterised Th isotope standards with compositions similar to those of geological samples. Hoffmann et al. ${ }^{444}$ present isotope ratio data for a variety of $U$ and Th CRMs, as well as carbonate and silicate standards. They obtained a ratio slightly greater than unity for ${ }^{230} \mathrm{Th} /{ }^{238} \mathrm{U}$ in Harwell uraninite and recommend that laboratories using this material for the calibration of their spikes should independently confirm the value for their batch of this RM.

\subsubsection{Other mass spectrometric techniques}

Thermal ionisation mass spectrometry (TIMS) continues to be applied to a variety of isotopic systems. Very precise and accurate $\mathrm{Nd}$ ratios are required in studies of Sm-Nd systematics; these are often limited by the amount of $\mathrm{Nd}$ in the samples. Problems observed by Upadhyay and colleagues ${ }^{447}$ due to fractionation and mixing of 
$\mathrm{Nd}$ isotopes during thermal ionisation were circumvented by Li et al. ${ }^{448}$, who used the $\mathrm{NdO}^{+}$technique for samples containing $<5 \mathrm{ng} \mathrm{Nd}$. They achieved an external precision of better than $30 \mathrm{ppm}$ for ${ }^{143} \mathrm{Nd} /{ }^{144} \mathrm{Nd}$, which was said to be comparable to that obtained for $\mathrm{Nd}^{+}$measurements of samples containing $200 \mathrm{ng} \mathrm{Nd}$. The determination of Ce isotopes by TIMS and MC-ICP-MS is challenging as the variation in global ${ }^{138} \mathrm{Ce} /{ }^{136} \mathrm{Ce}$ is small and the isobaric interference of ${ }^{138} \mathrm{Ba}$ is large. A comparison of data from both techniques indicated that measurement of $\mathrm{Ce}$ as an oxide species by TIMS, combined with accurate monitoring and correction for the ${ }^{140} \mathrm{Ce}$ low mass peak-tail as well as ${ }^{138} \mathrm{Ba}$, was the only way to produce accurate and reproducible Ce ratios ${ }^{351}$. A compilation of published data for ${ }^{138} \mathrm{Ce} /{ }^{136} \mathrm{Ce}$ in the Johnson Matthey $\mathrm{CeO}_{2} \mathrm{RM}$ JMC 304, which is no longer commercially available, revealed that this RM is probably not homogenous. Fortunately, a new Ce stock solution prepared from high purity $\mathrm{Ce}$ metal with a ${ }^{138} \mathrm{Ce} /{ }^{136} \mathrm{Ce}$ ratio of $1.33738 \pm$ $0.000005(\mathrm{n}=35)$ is now available. A detailed study of the effects of polyatomic interferences, mass fractionation and correction procedures that influence the quality of Os isotope data by N-TIMS has been published ${ }^{449}$. Tests performed on three Os RMs showed that differences of up to $21 \mathrm{ppm}$ in the ${ }^{186} \mathrm{Os} /{ }^{188} \mathrm{Os}$ ratio were evident, depending on the method used to correct for interferences from oxygen isotopes. Monitoring and correcting for interferences from $\mathrm{PtO}_{2}{ }^{-}$were considered to be mandatory for the measurement of ${ }^{184} \mathrm{Os} /{ }^{188} \mathrm{Os}$ in studies of nucleosynthetic processes. A comprehensive assessment of the uncertainties associated with the derivation of U$\mathrm{Pb}$ isotope ratios by TIMS has been undertaken ${ }^{450}$. Standard parametric statistical methods of error propagation were used to calculate the uncertainties arising at each step in the isotope measurements, isochron calculations and radiogenic model age calculations. It has been argued that the measurement of ${ }^{48} \mathrm{Ca} /{ }^{42} \mathrm{Ca}$ is preferable to that of ${ }^{44} \mathrm{Ca} /{ }^{40} \mathrm{Ca}$ for studies of the fractionation of $\mathrm{Ca}$ in biogeochemical processes ${ }^{451}$. The former pair of $\mathrm{Ca}$ isotopes avoids the effects of any in-growth of ${ }^{40} \mathrm{Ca}$ from the decay of ${ }^{40} \mathrm{~K}$ and provides a greater spread of isotopic masses. Analysis by TIMS using a ${ }^{43} \mathrm{Ca} /{ }^{46} \mathrm{Ca}$ double spike provided an external precision of $0.18 \%(2 \mathrm{~s})$.

A review of recent developments in stable isotope ratio mass spectrometry (IRMS) can be found in a sister Update in this series ${ }^{452}$. A system has been developed for analysing nanomolar quantities of silicate-derived $\mathrm{N}_{2}$ by combining a metal highvacuum extraction line with a continuous-flow gas chromatography interface ${ }^{453}$. The 
use of sealed tube combustion overcame problems of fractionation that occur with the shorter duration heating used in EA systems. Uncertainties were generally less than $5 \%$ for $\mathrm{N}$ concentrations and of the order of $0.15 \% \delta^{15} \mathrm{~N}$ for samples with $>5 \mathrm{ppm} \mathrm{N}$, which increased to about $0.6 \% \delta^{15} \mathrm{~N}$ for samples with $1-2 \mathrm{ppm} \mathrm{N}$. Following a review of the merits and disadvantages of techniques available for the extraction of chlorine from silicate samples and measurement of $\delta^{37} \mathrm{Cl}$, an optimised method based on pyrohydrolysis extraction and dual inlet gas source MS has been proposed ${ }^{454}$. All the samples analysed had negative $\delta^{37} \mathrm{Cl}$ values with a total variation of about $2 \%$, in contrast to data published by other workers showing a larger range of mainly positive values for comparable samples. The cause of this inconsistency was thought to be the result of incomplete recovery of $\mathrm{Cl}$ after extraction or purification, and underlined the need for inter-laboratory calibrations. Initial results obtained from a new approach to the determination of $\mathrm{O}$ isotopes in carbonates have been reported ${ }^{455}$. Analysis of CO produced by pyrolytic reduction at $>1400^{\circ} \mathrm{C}$ using an elemental analyser coupled to continuous flow IRMS offered the prospect of a more rapid procedure with minimal fractionation effects. The performance of six procedures commonly used to normalise isotope ratio measurements to the appropriate international reference scale have been assessed mathematically ${ }^{455}$. Computations showed that single-point anchoring produced errors that exceeded the maximum total uncertainties (such as $0.1 \%$ for $\delta^{13} \mathrm{C}$ ) reported in the literature and therefore should not be used. Normalisation methods using two or more CRMs were recommended provided the isotopic composition of the standards bracketed that of the unknown samples.

A new method has been developed to eliminate errors resulting from in situ contamination and $\mathrm{H}$ backgrounds when determining the $\mathrm{H}$ content of geological samples by $\operatorname{SIMS}^{456}$. It is based on measuring the same spot with different primary beam currents and applying a simple model for the sputtering of adsorbed $\mathrm{H}$ stemming from surface contamination of the sample while it is in the mass spectrometer. The NIST SRM 610 glass and synthetic enstatite crystals were used to test its validity. While the method requires an experienced SIMS operator, the total time is relatively short ( $<30 \mathrm{~min})$ and no complicated and time-consuming measures to reduce contamination are necessary. Analytical artefacts have been reported when measuring boron isotope ratios in silicate glasses by SIMS ${ }^{457}$. A difference of $3.4 \%$ was observed when NIST SRM 610 and 612 glasses, rather than natural geological 
reference glasses, were used to correct for instrumental mass fractionation (IMF). This matrix effect is significant when compared to the size of $B$ isotope variations in natural silicate systems, which hardly exceed $10 \%$. In their measurements of $\delta^{44} \mathrm{Ca}$ in calcite by SIMS, Rollion and coworkers ${ }^{458}$ found that IMF was independent of the intensity of the ${ }^{16} \mathrm{O}^{-}$primary beam and the magnesium content but could depend on the vacuum conditions. An analytical precision of $\pm 0.15 \%$ o $(1 \sigma)$ allowed them to quantify the intra-shell variability of $\delta^{44} \mathrm{Ca}$ in planktonic foraminifera. The geochemistry of coral skeletons may reflect seawater conditions at the time of deposition but can also be significantly affected by digenesis. Through selective analysis of primary coral and precipitated cements by SIMS, Allison et al. ${ }^{459}$ demonstrated that the primary coral aragonite structures maintained their original composition; thus altered coral skeletons could be used for accurate climate reconstructions ${ }^{459}$. In their development of an oxygen isotope thermometer based on monazite, Breecker and Sharp ${ }^{460}$ measured the mineral's $\mathrm{O}$ isotope composition using SIMS and multiple fluorination techniques. Their results indicated that differences in the thorium content of monazites can cause the IMF to vary by at least $4 \%$. Chemically distinct zones in the monazites studied appeared to have similar O isotope compositions, which could provide an uncorrupted record of peak metamorphic temperatures. In situ measurements of REEs in uranium oxide ores by SIMS demonstrated the utility of this technique in metallogenic studies.

A detailed overview of recent developments in $A M S$ is given in a sister Update ${ }^{452}$. Advantages of AMS for the determination of $U$ and actinides include its high sensitivity and good discrimination of molecular interferences. Thus very sensitive AMS measurements of $\mathrm{Pu}$ concentrations and isotope ratios in soils and sediments containing fg levels of $\mathrm{Pu}$ have been reported ${ }^{299}$. After sample dissolution and separation from uranium by ion-exchange chromatography, the $\mathrm{Pu}$ was concentrated into a small pellet by co-precipitation with iron oxide. Yields of between $60-80 \%$ were deemed acceptable, although it is clearly desirable to understand where the remainder of the $\mathrm{Pu}$ was being lost. In order to measure naturally-occurring ${ }^{236} \mathrm{U}$ and ${ }^{239} \mathrm{Pu}$ in the same sample of uranium ore, Wilken et al. ${ }^{461}$ developed a new sample preparation protocol to ensure efficient extraction of both elements and isotopic equilibrium between the ${ }^{239} \mathrm{Pu}$ in the ore and a ${ }^{242} \mathrm{Pu}$ spike. After dissolution with $\mathrm{HF}$, the uranium was separated by chromatography on resin specific for tetravalent $U$; the 
$\mathrm{Pu}$ fraction was purified further using an anion exchange resin. Good agreement $\left(\mathrm{R}^{2}=\right.$ 0.98 ) was achieved in a comparison of ${ }^{236} \mathrm{U}$ determinations in marine sediment $\mathrm{RMs}$ by AMS and high resolution ICP-MS ${ }^{462}$. Although both are very sensitive tools for the measurement of ultra low levels of radionuclides in the environment, AMS exhibited better sensitivity by two orders of magnitude, with a minimum LOD of $1 \times 10^{-8}$ for the ${ }^{236} \mathrm{U} /{ }^{238} \mathrm{U}$ atom ratio. Hunt and coworkers ${ }^{463}$ reported experiments designed to optimise the determination of ${ }^{26} \mathrm{Al}\left(\mathrm{Al}_{2} \mathrm{O}_{3}\right)$ by $\mathrm{AMS}$ for geochronological and geomorphological applications. They sought to identify alternative metal matrices, in which the $\mathrm{Al}_{2} \mathrm{O}_{3}$ is dispersed, and mixing ratios to enhance the ${ }^{26} \mathrm{Al}$ ion beam currents and thus improve the precision. However, no significant increase in ion current or efficiency was obtained using the novel matrices employed relative to those achieved with the current practice of mixing $\mathrm{Al}_{2} \mathrm{O}_{3}$ with silver in equimolar quantities. Fituoussi and Raisbeck ${ }^{464}$ have been working on a carrier-free method to extract $\mu \mathrm{g}$ amounts of I from marine sediments in order to date ones older than $10 \mathrm{M}$ years, and detect ${ }^{129} \mathrm{I}$ from a purported supernova explosion $\sim 2.8 \mathrm{M}$ years ago. The most efficient cleaning procedure also allowed the simultaneous isolation of authigenic ${ }^{26} \mathrm{Al}$ and ${ }^{60} \mathrm{Fe}$. Contamination placed an upper limit for ${ }^{129} \mathrm{I} /{ }^{127} \mathrm{I}$ of $1.4 \times 10^{-12}$ in reagent blanks of $50 \mu \mathrm{g}$. A large discrepancy between theoretically derived ratios and experimental data for ${ }^{129} \mathrm{I} /{ }^{127} \mathrm{I}$ in pre-anthropogenic sediments was noted. Very sensitive methods are required to detect any ${ }^{182} \mathrm{Hf}$ deposited in deep sea sediments from a nearby supernova. For accurate results by AMS, the interference from the ${ }^{182} \mathrm{~W}$ isobar has to be minimised by a combination of chemical separation, use of the $\mathrm{HfF}_{5}{ }^{-}$negative ion and separation of ${ }^{182} \mathrm{Hf}$ and ${ }^{182} \mathrm{~W}$ ions by measurement of their differences in energy loss in an absorber foil ${ }^{465}$. In spite of these improvements, the LOD reported was not sufficiently good to detect a supernova signal.

\subsubsection{X-ray techniques}

An excellent review of applications of XRF to the analysis of geological and industrial minerals has been published recently in a companion Update on $\mathrm{XRFS}^{88}$. In spite of the continued growth in the use of ICP-MS, XRFS continues to be used widely in geochemical research because its strengths and weaknesses complement those of ICP-MS to a large extent. This point is exemplified in a report of the 
analytical techniques employed by the Chinese in their regional and national geochemical mapping programmes ${ }^{341}$.

The chemical characterisation of archaeological materials often takes advantage of the non-destructive nature of in situ XRF analysis. Artefacts made of obsidian can usually be linked to their mineralogical source with a high degree of certainty. This is because sources of obsidian tend to be chemically homogeneous, have unique chemical signatures and the artefacts are virtually indestructible. Craig and co-workers ${ }^{466}$ demonstrated that principal component analysis of data for six elements (N, Fe, Rb, Sr, Zn and Zr) obtained on 68 whole Peruvian obsidian artefacts by both laboratory ED-XRF and portable XRF arrived at identical conclusions. Individual elemental comparisons showed significant differences, but these could be resolved through instrument cross calibration and they had no bearing source identification. In a study of obsidians taken from the principal geological outcrops of interest around the Mediterranean ${ }^{467}$, results obtained on powders using routine WDXRF were compared with non-destructive XRF methodology, using the same spectrometer, on splinters of obsidian having a similar shape to discarded material usually found at archaeological sites. Both methods were able to discriminate between the different sources of obsidian even though only five trace elements $(\mathrm{Nb}, \mathrm{Rb}, \mathrm{Sr}, \mathrm{Y}$ and $\mathrm{Zr}$ ) were determined with the non-destructive approach. Lundblad et al. ${ }^{468}$ demonstrated the ability of ED-XRF to discriminate between basalt sources through non-destructive analysis of basalt artefacts from Hawaii. The effect of variations in surface weathering and irregularities in the size, shape and surface texture of the specimen on the precision and accuracy of the measurements were assessed. Data for $\mathrm{Nb}, \mathrm{Rb}, \mathrm{Sr}, \mathrm{Y}$ and $\mathrm{Zr}$ showed no statistical differences between fresh and weathered surfaces and, for these elements, the thickness of the sample only affected the reproducibility significantly only when it was less than $1 \mathrm{~mm}$. A minimum surface area of $100 \mathrm{~mm}^{2}$ was required, although the use of a collimated beam would be expected to reduce the sample size necessary for analysis. The effects of highly curved surfaces were not considered.

There is growing interest in studying small scale geochemical variations in sediment cores as they can provide records of past climate changes on an annual or even seasonal scale. Shanahan and co-workers ${ }^{469}$ demonstrated the use of scanning $\mu$ XRF for elemental mapping of laminated lake cores on eight sediment types from a variety of depositional environments. This approach, which complements other 
techniques such as SEM, provided information on spatial variations in major and trace element chemistry that contributed to understanding changes in lake stability and redox conditions. Existing procedures to establish TOC profiles in sediment cores require the analysis of discrete samples, so Ziegler et al. ${ }^{470}$ sought to use $\mathrm{Br}$ determined by XRF core scanning technology as a surrogate for TOC. Overall the $\mathrm{Br}$ counts and TOC showed a clear correlation except when carbon isotope data and $\mathrm{C} / \mathrm{N}$ ratios indicated intervals characterised by an enhanced input of terrestrial organic matter. Thus, solid phase $\mathrm{Br}$ was exclusively associated with marine organic matter and could be used to estimate it directly once a calibration between the two had been established. The authors concluded that the Br signal from $\mu$-XRF scanning of cores could be used as a quick and non-destructive, high resolution, semi-quantitative estimate of sedimentary TOC.

Micro-focused synchrotron radiation techniques are being increasingly used in research into nuclear waste disposal as well as more fundamental geochemical studies. A section of core from uranium-rich sediment collected in the Czech Republic, provided a natural analogue for studies of geochemical transformations that could occur in a waste repository in deep geological formations ${ }^{471}$. Elemental distributions and their chemical states were obtained by $\mu$-XRF measurements; arsenic oxidation states were determined from $\mu$-XANES and the crystalline structure of selected regions examined by $\mu$-XRD. The confocal geometry employed with $\mu-$ XANES had the advantages of minimal sample preparation and enabled volumes below the surface to be studied. This overcame the problem of changes in the As valance state observed in some regions of the sample when thin sections were prepared, and supported their proposed mechanism for U-enrichment in the sediment. Synchrotron-based $\mu$-XRF has also been used to investigate the speciation of $U$ in precipitates formed in sediments beneath a processing pond in Washington, USA ${ }^{472}$. From these studies, mineral controls on the long term release of $U$ to the groundwater were established. Synchrotron radiation XRF is able to penetrate a rock sample to depths of several millimetres, much greater than the penetration depths of other nondestructive techniques. This capability made it suitable for detecting micrometer-scale PGE mineral grains in samples of mantle peridotite ${ }^{473}$ and analysing individual fluid inclusions ${ }^{474}$ without damage to the samples prepared as thin sections or thick wafers. 


\section{Glossary of terms}

Terms include the plural form.

AAS

ACGIH

AES

AFS

AMS

BCR

BP

CCA

$\mathrm{CCC}$

CCD

CE

CE-UV

CE-ICP-MS

CEM

CRM

$\mathrm{CV}$

CV-AAS

CV-AFS

DBT

DDTC

DIBK

DMA

DNPH

DPhT

DRC

EA

EC

EDAX
Atomic Absorption Spectrometry

American Conference of Governmental Industrial Hygienists

Atomic Emission Spectrometry

Atomic Fluorescence Spectrometry

Accelerator Mass Spectrometry

Community Bureau of Reference

Before Present

Copper Chromium Arsenic

Counter Current Chromatography

Charged coupled device

Capillary Electrophoresis

Capillary Electrophoresis-Ultraviolet Spectrophotometry

Capillary Electrophoresis-Inductively Coupled Plasma-Mass

Spectrometry

Continuous Emission Monitoring

Certified Reference Material

Cold vapour

Cold Vapour Atomic Absorption Spectrometry

Cold Vapour Atomic Fluorescence Spectrometry

Dibutyltin

Diethyldithiocarbamate

Disobutyl ketone

Dimethyl arsenic acid

2,4-dinitrophenylhydrazine

Diphenyltin

Dynamic reaction cell

Elemental analyser

Elemental Carbon

Energy Dispersive Spectrometry 


\begin{tabular}{|c|c|}
\hline EDXRF & Energy Dispersive X-ray Fluorescence \\
\hline EDTA & Ethylenediaminetetraacetic acid \\
\hline EPA & Environmental Protection Agency \\
\hline EN & European Committee for Standardisation \\
\hline EMPA & Electron Microprobe Analyser \\
\hline ES-MS & Electrospray-Mass Spectrometry \\
\hline ETAAS & Electrothermal Atomic Absorption Spectrometry \\
\hline ETV-AAS & Electrothermal Vaporisation- Atomic Absorption Spectrometry \\
\hline \multirow[t]{2}{*}{ ETV-ICP-MS } & Electrothermal Vaporisation-Inductively Coupled Plasma-Mass \\
\hline & Spectrometry \\
\hline EXAFS & Extended X-ray Absorption Fine Structure) \\
\hline FI & Flow Injection \\
\hline \multirow[t]{2}{*}{ FI-CV-ICP-MS } & Flow injection-Cold Vapour-Inductively Coupled Plasma-Mass \\
\hline & Spectrometry \\
\hline \multirow[t]{2}{*}{ FI-HG-QF-AAS } & Flow injection-Hydride Generation-Quartz Furnace- Atomic \\
\hline & Absorption Spectrometry \\
\hline FI-ICP-MS & Flow injection-Inductively Coupled Plasma-Mass Spectrometry \\
\hline FP & Fundamental Parameter \\
\hline$f_{S}$ & Femto second \\
\hline FTIR & Fourier Transform Infrared \\
\hline GC & Gas Chromatography \\
\hline GC-AED & Gas Chromatography-Atomic Emission Detector \\
\hline GC-AFS & Gas Chromatography- Atomic Fluorescence Spectrometry \\
\hline \multirow[t]{2}{*}{ GC-C-IR-MS } & Gas Chromatography-Combustion-Isotope Ratio-Mass \\
\hline & Spectrometry \\
\hline GC-FPD & Gas Chromatographic-Flame Photometric Detector \\
\hline \multirow[t]{2}{*}{ GC-ICP-MS } & Gas Chromatography-Inductively Coupled Plasma-Mass \\
\hline & Spectrometry \\
\hline GC-IR-MS & Gas Chromatography-Isotope Ratio-Mass Spectrometry \\
\hline \multirow[t]{2}{*}{ GC-MIP-AES } & Gas Chromatography-Microwave Induced Plasma-Atomic \\
\hline & Emission Spectrometry \\
\hline GC-MS & Gas Chromatography-Mass Spectrometry \\
\hline GC-TOF-MS & Gas Chromatography-Time of Flight-Mass Spectrometry \\
\hline GF-AAS & Graphite Furnace-Atomic Absorption Spectrometry \\
\hline
\end{tabular}




\begin{tabular}{|c|c|}
\hline GPS & Global Positioning System \\
\hline GSJ & Geological Survey of Japan \\
\hline $\mathrm{HCL}$ & Hollow cathode lamp \\
\hline HDPE & High Density Polyethylene \\
\hline HFA & Hexafluoroarsenate \\
\hline HG & Hydride Generation \\
\hline HG-AAS & Hydride Generation-Atomic absorption Spectrometry \\
\hline HG-AFS & Hydride Generation-Atomic Fluorescence Spectrometry \\
\hline \multirow[t]{2}{*}{ HG-ICP-MS } & Hydride Generation- Inductively Coupled Plasma-Mass \\
\hline & Spectrometry \\
\hline \multirow[t]{2}{*}{ HG-QT-AAS } & Hydride Generation-Quartz Tube- Atomic Absorption \\
\hline & Spectrometry \\
\hline HPLC & High Performance Liquid Chromatography \\
\hline \multirow[t]{2}{*}{ HPLC-ICP-MS } & High Performance Liquid Chromatography- Inductively \\
\hline & Coupled Plasma-Mass Spectrometry \\
\hline \multirow[t]{2}{*}{ HPLC-DF-ICP-MS } & High Performance Liquid Chromatography-Double Focusing- \\
\hline & Inductively Coupled Plasma-Mass Spectrometry \\
\hline \multirow[t]{2}{*}{ HPLC-HG-AFS } & High Performance Liquid Chromatography- Atomic \\
\hline & Fluorescence Spectrometry \\
\hline IAG & International Association of Geoanalysts \\
\hline $\mathrm{IC}$ & Ion Chromatography \\
\hline \multirow[t]{2}{*}{ IC-HG-AFS } & Ion Chromatography-Hydride Generation-Atomic Fluorescence \\
\hline & Spectrometry \\
\hline \multirow[t]{2}{*}{ IC-ICP-MS } & Ion Chromatography- Inductively Coupled Plasma-Mass \\
\hline & Spectrometry \\
\hline ICP-AES & Inductively Coupled Plasma-Atomic Emission Spectrometry \\
\hline ICP-MS & Inductively Coupled Plasma-Mass Spectrometry \\
\hline ICP-TOF-MS & Inductively Coupled Plasma-Time of Flight-Mass Spectrometry \\
\hline ID & Isotope Dilution \\
\hline \multirow[t]{2}{*}{ ID-ICP-MS } & Isotope Dilution- Inductively Coupled Plasma-Mass \\
\hline & Spectrometry \\
\hline ID-MS & Isotope Dilution-Mass Spectrometry \\
\hline IGGE & Institute of Geophysical and Geochemical Exploration \\
\hline IMF & Instrumental mass fractionation \\
\hline
\end{tabular}


INAA Instrumental Neutron Activation Analysis

IR Infra Red

IRMM

Institute for Reference Materials and Measurements

IRMS

Isotope Ratio Mass Spectrometry

ISO

International Standards Organisation

LA

Laser Ablation

LA-ICP-MS Laser Ablation-Inductively Coupled Plasma-Mass

Spectrometry

LA-MC-ICP-MS Laser Ablation- Multi Collector- Inductively Coupled PlasmaMass Spectrometry

LC-HG-AFS Liquid Chromatography-Hydride Generation-Atomic

Fluorescence Spectrometry

LC-ICP-MS Liquid Chromatography-Inductively Coupled Plasma-Mass

Spectrometry

LC-MS Liquid Chromatography-Mass Spectrometry

LC-MS-MS LiquidChromatography-Mass Spectrometry-Mass SpectrometryLIBS

Laser Induced Breakdown Spectrometry

LOD Limit of Detection

LOQ Limit of Quantification

MA Methylarsonic acid

MBT Monobutyltin

MC-ICP-MS Multi Collector- Inductively Coupled Plasma-Mass

Spectrometry

MDL

Method Detection Limit

MIC

Microwave induced combustion

MIP-AES

Microwave Induced Plasma- Atomic Emission Spectrometry

MMA

Monomethyl arsenic

$\mathrm{MeHg}$

Methyl Mercury

$\mathrm{Me}_{2} \mathrm{Hg}$

Dimethyl Mercury

MPhT

Monophenyltin

MS/MS

Tandem Mass Spectrometry

NAA

Neutron Activation Analysis

NAAQS

National Ambient Air Quality Standards

$\mathrm{Nd}: Y A G$

Neodymium Doped:Yttrium Aluminum Garnet 
NEXAFS

NIES

NIOSH

NIST

NMI

NRCC

NTIMS

OC

ORS

PESA

PGE

PIXE

PFA

PLE

PTFE

P-EDXRF

ps

PXRF

REE

$\mathrm{RM}$

RSD

RSE

RTI

SARM

$\mathrm{SeCN}$

SEM

SF-ICP-MS

SHRIMP

SIMS

SIRMS

$\mathrm{S} / \mathrm{N}$

SPE

SPME

SRM
Near Edge X-ray Absorption Fine Structure

National Institute for Environmental Sciences

National Institute of Occupational Safety and Health

National Institute of Standards and Technology

National Measurement Institute

National Research Council of Canada

Negative Thermal Ionisation Mass Spectrometry

Organic Carbon

Octopole reaction cell

Proton Elastic Scattering Analysis

Precious Group Element

Particle-Induced X-ray Emission

Perfluoroalkoxy

Pressurised Liquid Extraction

Poly(tetrafluoroethylene)

Polarised-Energy Dispersive X-ray Fluorescence

pico second

Portable X-ray Fluorescence

Rare Earth Element

Reference Material

Relative Standard Deviation

Relative Standard Error

Research Triangle Institute

South African Reference Material

Selenocyanate

Scanning Electron Microscopy

Sector Field Inductively Coupled Plasma-Mass spectrometry

Sensitive High mass Resolution Ion Microprobes

Secondary Ion Mass Spectrometry

Stable Isotope Ratio Mass Spectrometry

Signal to Noise ratio

Solid Phase Extraction

Solid Phase Microextraction

Standard Reference Material 
SR

SRXRF

STN

STXM

SSID

TBT

TD-GC-ICP-MS

TD-GC-IR-MS

TEM

TIMS

TMAO

$\mathrm{TMSb}$

TOC

TOF-SIMS

TOK

TOT

$\mathrm{TPhT}$

TSP

TXRF

USGS

UV

WDXRF

XAFS

XANES

XRD

XRF

US EPA

VOC

VG

WHO

ZAAS
Synchrotron Radiation

Synchrotron Radiation X-ray Fluorescence

Speciation Trends Network

Scanning Transmission X-ray Microscope

Species Specific Isotope Dilution

Tributyltin

Thermal Desorption-Gas Chromatography-Inductively Coupled Plasma-Mass Spectrometry

Thermal Desorption-Gas Chromatography-Isotope Ratio-Mass Spectrometry

Transmission Electron Microscopy

Thermal Ionisation Mass Spectrometry

Trimethylarsine oxide

Trimethylantimony dichloride

Total organic carbon

Time of Flight- Secondary Ion Mass Spectrometry

Thermal Optical Kinetic

Thermal Optical Transmission

Triphenyltin

Total suspended particles

Transmission X-ray Fluorescence

United States Geological Survey

Ultra Violet

Wavelength Dispersive X-ray Fluorescence

X-ray Absorption Fine Structure Spectrometry

X-Ray Absorption Near Edge Structure

X-ray Diffraction

X-ray Fluorescence

United States Environmental Protection Agency

Volatile Organic Carbon

Vapour Generation

World Health Organisation

Zeeman Atomic Absorption Spectrometry 


\section{References}

1 O. T. Butler, J. M. Cook, C. F. Harrington, S. J. Hill, J. Rieuwerts and D. L. Miles, Journal of Analytical Atomic Spectrometry, 2008, 23(2), 249-286.

2 J. C. Chow, P. Doraiswamy, J. G. Watson, L. W. Antony-Chen, S. S. H. Ho and D. A. Sodeman, Journal of the Air \& Waste Management Association, 2008, 58(2), 141-163.

3 W. Maenhaut, Atmospheric Environment, 2008, 42(5), 1070-1072.

4 H. J. Wen and J. Carignan, Atmospheric Environment, 2007, 41, 7151-7165.

$5 \quad$ P. Smichowski, Talanta, 2008, 75(1), 2-14.

6 W. Shotyk and G. Le Roux, in Biogeochemical Cycles of Elements, Vol. 43, Taylor \& Francis Ltd, London, 2005, pp. 239-275.

7 E. G. Pacyna, J. M. Pacyna, J. Fudala, E. Strzelecka-Jastrzab, S. Hlawiczka, D. Panasiuk, S. Nitter, T. Pregger, H. Pfeiffer and R. Friedrich, Atmospheric Environment, 2007, 41(38), 8557-8566.

8 M. M. Maricq, Journal of Aerosol Science, 2007, 38, 1079-1118.

9 M. D. A. Korn, D. S. S. dos Santos, B. Welz, M. G. R. Vale, A. P. Teixeira, D. D. Lima and S. L. C. Ferreira, Talanta, 2007, 73(1), 1-11.

10 A. Dubiella-Jackowska, Z. Polkowska and J. Namiesnik, Polish Journal of Environmental Studies, 2007, 16(3), 329-345.

11 P. Smichowski, D. Gomez, C. Frazzoli and S. Caroji, Applied Spectroscopy Reviews, 2008, 43(1), 22-48.

12 M. E. Ketterer and S. C. Szechenyi, Spectrochimica Acta Part B-Atomic Spectroscopy, 2008, 63(7), 719-737.

13 H. M. Ortner, Journal of Analytical Atomic Spectrometry, 2007, 22(6), 599607.

14 J. R. Bacon and C. M. Davidson, Analyst, 2008, 133(1), 25-46.

15 C. R. M. Rao, A. Sahuquillo and J. F. L. Sanchez, Water Air and Soil Pollution, 2008, 189(1-4), 291-333.

16 M. Sillanpaa, M. D. Geller, H. C. Phuleria and C. Sioutas, Journal of Aerosol Science, 2008, 39(4), 335-347.

17 M. Ranjan and S. Dhaniyala, Journal of Aerosol Science, 2007, 38, 950-963.

18 C. L. Qi, D. R. Chen and P. Greenberg, Aerosol Science and Technology, 2008, 42(7), 505-512.

19 L. Ntziachristos, Z. Ning, M. D. Geller, R. J. Sheesley, J. J. Schauer and C. Sioutas, Atmospheric Environment, 2007, 41(27), 5684-5696.

20 C. J. Tsai, C. S. Chang, S. C. Chen, P. Chen, T. S. Shih, D. Y. H. Pui, V. V. Karasev, A. A. Onischuk and S. N. Li, Aerosol Science and Technology, 2008, 42(1), 86-95.

21 M. W. Case, R. Williams, K. Yeatts, F. L. Chen, J. Scott, E. Svendsen and R. B. Devlin, Atmospheric Environment, 2008, 42(19), 4446-4452.

22 N. P. Hyslop and W. H. White, Atmospheric Environment, 2008, 42(11), 2691-2705.

23 J. C. Hains, L. W. A. Chen, B. F. Taubman, B. G. Doddridge and R. R. Dickerson, Atmospheric Environment, 2007, 41, 6167-6184.

24 D. K. Ott, W. Cyrs and T. A. Peters, Journal of Aerosol Science, 2008, 39(2), 156-167.

25 T. A. Mather, D. M. Pyle and T. H. E. Heaton, Atmospheric Environment, 2008, 42(19), 4611-4618. 

Heaton, H. J. Sloane and G. R. Fern, Journal of Geophysical ResearchAtmospheres, 2007, 112(D9).

27 J. H. Won, J. Y. Park and T. G. Lee, Atmospheric Environment, 2007, 41(35), 7547-7552.

28 H. Agrawal, A. A. Sawant, K. Jansen, J. W. Miller and D. R. Cocker, Atmospheric Environment, 2008, 42(18), 4380-4392.

29 S. A. N. Sheya, C. Glowacki, M. C. O. Chang, J. C. Chow and J. G. Watson, Journal of the Air \& Waste Management Association, 2008, 58(4), 553-561.

30 P. Kulkarni, S. Chellam, J. B. Flanagan and R. K. M. Jayanty, Analytica Chimica Acta, 2007, 599(2), 170-176.

31 B. Bocca, M. E. Conti, A. Pino, D. Mattei, G. Forte and A. Alimonti, International Journal of Environmental Analytical Chemistry, 2007, 87(15), 1111-1123.

32 P. E. Rasmussen, A. J. Wheeler, N. M. Hassan, A. Filiatreault and M. Lanouette, Atmospheric Environment, 2007, 41(28), 5897-5907.

33 I. Mori, Z. J. Sun, M. Ukachi, K. Nagano, C. W. McLeod, A. G. Cox and M. Nishikawa, Analytical and Bioanalytical Chemistry, 2008, 391(6), 1997-2003.

34 R. Kips, A. Leenaers, G. Tamborini, M. Betti, S. Van den Berghe, R. Wellum and P. Taylor, Microscopy and Microanalysis, 2007, 13(3), 156-164.

35 B. R. Conard, N. Zelding and G. T. Bradley, Journal of Environmental Monitoring, 2008, 10(4), 532-540.

36 J. D. Noel, P. Biswas and D. E. Giammar, Journal of the Air \& Waste Management Association, 2007, 57(7), 856-867.

37 J. Sysalova and J. Szakova, Chem. Pap., 2007, 61(4), 271-275.

38 P. Smichowski, G. Polla, D. Gomez, A. J. F. Espinosa and A. C. Lopez, Fuel, 2008, 87(7), 1249-1258.

39 E. Alonso-Rodriguez, J. Moreda-Pineiro, P. Lopez-Mahia, S. MuniateguiLorenzo, D. Prada-Rodriguez, A. Moreda-Pineiro and P. Bermejo-Barrera, Journal of Analytical Atomic Spectrometry, 2007, 22(9), 1089-1096.

40 T. Falta, A. Limbeck, G. Koellensperger and S. Hann, Analytical and Bioanalytical Chemistry, 2008, 390(4), 1149-1157.

41 B. J. Majestic, J. J. Schauer and M. M. Shafer, Aerosol Science and Technology, 2007, 41, 925-933.

42 J. F. Fabretti, N. Sauret, J. F. Gal, P. C. Maria and U. Scharer, Ann. Chim., 2007, 97(9), 875-885.

43 P. Krystek and R. Ritsema, International Journal of Mass Spectrometry, 2007, 265(1), 23-29.

44 Y. F. Zhang, Z. C. Jiang, M. He and B. Hu, Environmental Pollution, 2007, 148(2), 459-467.

45 R. Yoshiie, Y. Yamamoto, S. Uemiya, S. Kambara and H. Moritomi, Powder Technology, 2008, 180(1-2), 135-139.

46 S. C. Kang, Q. G. Zhang, S. Kaspari, D. H. Qin, Z. Y. Cong, J. W. Ren and P. A. Mayewski, Atmospheric Environment, 2007, 41(34), 7208-7218.

47 Z. Q. L1, C. J. L1, Y. F. L1, F. T. Wang and H. L. L1, Journal of Glaciology, 2007, 53(182), 368-373.

48 A. M. G. Pacheco, M. C. Freitas, M. S. Baptista, M. Vasconcelos and J. P. Cabral, Journal of Radioanalytical and Nuclear Chemistry, 2008, 276(1), 135141. 
49 L. Barandovski, M. Cekova, M. V. Frontasyeva, S. S. Pavlov, T. Stafilov, E. Steinnes and V. Urumov, Environmental Monitoring and Assessment, 2008, 138(1-3), 107-118.

50 K. P. Singh, V. K. Singh, A. Malik, N. Sharma, R. C. Murthy and R. Kumar, Environ. Monit. Assess., 2007, 131(1-3), 237-254.

51 T. Shimamura, M. Iwashita, S. Iijima, M. Shintani and Y. Takaku, Atmospheric Environment, 2007, 41(33), 6999-7010.

52 Y. Dogan, N. Durkan and S. Baslar, Trace Elements and Electrolytes, 2007, 24(3), 146-150.

53 Y. W. Kuang, G. Y. Zhou, D. Z. Wen and S. Z. Liu, Environmental Science and Pollution Research, 2007, 14(4), 270-275.

54 G. J. Patrick and J. G. Farmer, Science of the Total Environment, 2007, 388(13), 343-356.

55 M. Daud, N. Khalid, J. Iqbal and S. Ahmad, Radiochimica Acta, 2007, 95(7), 423-431.

56 C. Zaccone, C. Cocozza, A. K. Cheburkin, W. Shotyk and T. M. Miano, Geoderma, 2007, 141(3-4), 235-246.

57 A. Klos, M. Rajfur, M. Waclawek, W. Waclawek, M. V. Frontasyeva and J. S. Pankratova, Water Air and Soil Pollution, 2008, 191(1-4), 345-352.

58 Y. Suzuki, I. Watanabe, T. Oshida, Y. J. Chen, L. K. Lin, Y. H. Wang, K. C. Yang and K. Kuno, Chemosphere, 2007, 68(7), 1270-1279.

59 A. Goncalves, J. R. Dominguez and J. Alvarado, Talanta, 2008, 75(2), 523527.

60 I. Iavicoli, G. Carelli, B. Bocca, S. Caimi, L. Fontana and A. Alimonti, Chemosphere, 2008, 71(3), 568-573.

61 H. Wichmann, G. A. K. Anquandah, C. Schmidt, D. Zachmann and M. A. Bahadir, Science of the Total Environment, 2007, 388(1-3), 121-127.

62 R. A. Sutherland, D. G. Pearson and C. J. Ottley, Environmental Pollution, 2008, 151(3), 503-515.

63 A. Limbeck, C. Puls and M. Handler, Environ. Sci. Technol., 2007, 41(14), 4938-4945.

64 M. S. Landis, C. W. Lewis, R. K. Stevens, G. J. Keeler, J. T. Dvonch and R. T. Tremblay, Atmospheric Environment, 2007, 41(38), 8711-8724.

65 A. P. Rutter, K. L. Hanford, J. T. Zwers, A. L. Perillo-Nicholas, J. J. Schauer and M. L. Olson, Journal of the Air \& Waste Management Association, 2008, 58(3), 377-383.

66 S. P. Sylva, L. Ball, R. K. Nelson and C. M. Reddy, Rapid Communications in Mass Spectrometry, 2007, 21(20), 3301-3305.

67 A. Cocherie and M. Robert, Chem. Geol., 2007, 243(1-2), 90-104.

68 S. R. Noble, M. S. A. Horstwood, P. Davy, V. Pashley, B. Spiro and S. Smith, Journal of Environmental Monitoring, 2008, 10(7), 830-836.

69 J. E. Sonke, T. Zambardi and J. P. Toutain, Journal of Analytical Atomic Spectrometry, 2008, 23(4), 569-573.

70 X. P. Wang and J. L. Zhang, Spectrosc. Spectr. Anal., 2007, 27(7), 1428-1432.

71 Y. Y. Yoon, C. S. Kim, D. Y. Yang, W. H. Nahm, S. Y. Cho and K. Y. Lee, Journal of Radioanalytical and Nuclear Chemistry, 2008, 276(1), 187-191.

72 J. Zheng, F. C. Wu, M. Yamada, H. Q. Liao, C. Q. Liu and G. J. Wan, Environmental Pollution, 2008, 152(2), 314-321. 
73 F. Gauthier-Lafaye, L. Pourcelot, J. Eikenberg, H. Beer, G. Le Roux, L. P. Rhikvanov, P. Stille, P. Renaud and A. Mezhibor, Journal of Environmental Radioactivity, 2008, 99(4), 680-693.

74 E. L. Goldberg, K. B. Zolotarev, V. V. Maksimovskaya, V. I. Kondratyev, D. V. Ovchinnikov and M. M. Naurzbaev, Nucl. Instrum. Methods Phys. Res. Sect. A-Accel. Spectrom. Dect. Assoc. Equip., 2007, 575(1-2), 196-198.

75 M. A. Phedorin, V. A. Bobrov and K. V. Zolotarevd, Nucl. Instrum. Methods Phys. Res. Sect. A-Accel. Spectrom. Dect. Assoc. Equip., 2007, 575(1-2), 199201.

76 A. E. S. de Vives, S. Moreira, S. M. B. Brienza, J. G. S. Medeiros, M. Tornazello, O. L. Araujo, D. Zucchi, V. F. do Nascimento and R. C. Barroso, Nucl. Instrum. Methods Phys. Res. Sect. A-Accel. Spectrom. Dect. Assoc. Equip., 2007, 579(1), 494-498.

77 Z. Q. Xie, P. F. Zhang, L. G. Sun, S. Q. Xu, Y. Y. Huang and W. He, Marine Pollution Bulletin, 2008, 56(3), 516-524.

78 J. Hasegawa, T. Tada, Y. Oguri, M. Hayashi, T. Toriyama, T. Kawabata and K. Masai, Rev. Sci. Instrum., 2007, 78(7).

79 K. Slezakova, M. C. Pereira, M. A. Reis and M. C. Alvim-Ferraz, Journal of Atmospheric Chemistry, 2007, 58(1), 55-68.

80 G. Lammel, D. G. Baumgardner, U. E. A. Fittschen and B. Peschel, International Journal of Environmental Analytical Chemistry, 2007, 87(9), 659-672.

81 W. S. Yue, X. L. Li, J. F. Liu, Y. L. Li, G. L. Zhang and Y. Li, Journal of Radioanalytical and Nuclear Chemistry, 2007, 274(1), 115-121.

82 C. J. Ma and K. C. Choi, Water Air Soil Pollut., 2007, 183(1-4), 3-13.

83 A. J. Antolak, D. H. Morse, P. G. Grant, P. G. Kotula, B. L. Doyle and C. B. Richardson, Nucl. Instrum. Methods Phys. Res. Sect. B-Beam Interact. Mater. Atoms, 2007, 261(1-2), 470-474.

84 Y. S. Wang, A. G. Li, Y. X. Zhan, L. Wei, Y. Li, G. L. Zhang, Y. N. Xie, J. Zhang, Y. M. Zhang and Z. C. Shan, Journal of Radioanalytical and Nuclear Chemistry, 2007, 273(1), 247-251.

85 F. Goodarzi, F. E. Huggins and H. Sanei, International Journal of Coal Geology, 2008, 74(1), 1-12.

86 R. J. Hopkins, Y. Desyaterik, A. V. Tivanski, R. A. Zaveri, C. M. Berkowitz, T. Tyliszczak, M. K. Gilles and A. Laskin, Journal of Geophysical ResearchAtmospheres, 2008, 113(D4).

87 J. Bramante, R. Z. Hinrichs, E. C. Brown and S. Calvin, Atmospheric Environment, 2007, 41(35), 7649-7653.

88 M. West, A. T. Ellis, P. Kregsamer, P. J. Potts, C. Streli, C. Vanhoof and P. Wobrauschek, Journal of Analytical Atomic Spectrometry, 2008, 23(10), 1409-1437.

89 T. M. Jenk, S. Szidat, M. Schwikowski, H. W. Gaggeler, L. Wacker, H. A. Synal and M. Saurer, Nucl. Instrum. Methods Phys. Res. Sect. B-Beam Interact. Mater. Atoms, 2007, 259(1), 518-525.

90 Y. Muramatsu, Y. Takada, H. Matsuzaki and S. Yoshida, Quaternary Geochronology, 2008, 3(3), 291-297.

91 E. Englund, A. Aldahan, G. Possnert and V. Alfimov, Nucl. Instrum. Methods Phys. Res. Sect. B-Beam Interact. Mater. Atoms, 2007, 259(1), 365-369. 
92 X. L. Zhao, C. Soto, W. E. Kieser, A. E. Litherland, B. L. Tracy, K. Ungar and T. Stocki, Nucl. Instrum. Methods Phys. Res. Sect. B-Beam Interact. Mater. Atoms, 2007, 259(1), 345-350.

93 K. Horluchi, T. Uchida, Y. Sakamoto, A. Ohta, H. Matsuzaki, Y. Shibata and H. Motoyama, Quaternary Geochronology, 2008, 3(3), 253-261.

94 U. Heikkila, J. Beer and V. Alfimov, Journal of Geophysical ResearchAtmospheres, 2008, 113(D11).

95 M. Henning, D. Strapoc, G. P. Lis, P. Sauer, J. Fong, A. Schimmelmann and L. M. Pratt, Rapid Commun. Mass Spectrom., 2007, 21(14), 2269-2272.

96 S. Nogues, I. Aranjuelo, A. Pardo and J. Azcon-Bieto, Rapid Communications in Mass Spectrometry, 2008, 22(7), 1017-1022.

97 S. J. Guo, S. Wen, G. W. Zu, X. M. Wang, G. Y. Sheng and J. M. Fu, Chinese Journal of Analytical Chemistry, 2008, 36(1), 19-23.

98 X. Chen and J. Z. Yu, Atmospheric Environment, 2007, 41(39), 8857-8864.

99 M. Viana, W. Maenhaut, H. M. ten Brink, X. Chi, E. Weijers, X. Querol, A. Alastuey, P. Mikuska and Z. Vecera, Atmospheric Environment, 2007, 41, 5972-5983.

100 S. Saarikoski, A. Frey, T. Makela and R. Hillamo, Aerosol Science and Technology, 2008, 42(8), 603-612.

101 L. G. Rebits, D. J. Bennett, P. A. Bhagwat, A. Morin and R. E. Sievers, Journal of Aerosol Science, 2007, 38(12), 1197-1206.

102 J. Fritsche, D. Obrist, M. J. Zeeman, F. Conen, W. Eugster and C. Alewell, Atmospheric Environment, 2008, 42(13), 2922-2933.

103 S. F. Wang, X. B. Feng, G. G. Qiu, L. H. Shang, P. Li and Z. Q. Wei, Atmospheric Environment, 2007, 41, 5984-5993.

104 S. Brooks, S. Lindberg, G. Southworth and R. Arimoto, Atmospheric Environment, 2008, 42(12), 2885-2893.

105 S. Brooks, R. Arimoto, S. Lindberg and G. Southworth, Atmospheric Environment, 2008, 42(12), 2877-2884.

106 R. J. C. Brown, A. S. Brown, R. E. Yardley, W. T. Corns and P. B. Stockwell, Atmospheric Environment, 2008, 42(10), 2504-2517.

107 E. S. Simpson, G. A. Lithgow and S. G. Buckley, Spectrochimica Acta Part BAtomic Spectroscopy, 2007, 62(12), 1460-1465.

108 D. Mukherjee and M. D. Cheng, Journal of Analytical Atomic Spectrometry, 2008, 23(1), 119-128.

109 P. K. Diwakar, P. B. Jackson and D. W. Hahn, Spectrochimica Acta Part BAtomic Spectroscopy, 2007, 62(12), 1466-1474.

110 D. Mukherjee and M. D. Cheng, Applied Spectroscopy, 2008, 62(5), 554-562.

111 J. Jiang, Y. F. Huan, W. Jin, G. D. Feng, Q. Fei, Y. B. Cao and Q. H. Jin, Spectroscopy and Spectral Analysis, 2007, 27(11), 2375-2379.

112 M. Diana, N. Gabrielli and S. Ridolfi, X-Ray Spectrometry, 2007, 36(6), 424428.

113 F. Drewnick, M. Dall'Osto and R. Harrison, Atmospheric Environment, 2008, 42(13), 3006-3017.

114 J. Schneider, U. Kirchner, S. Borrmann, R. Vogt and V. Scheer, Atmospheric Environment, 2008, 42(18), 4257-4268.

115 S. M. Toner, L. G. Shields, D. A. Sodeman and K. A. Prather, Atmospheric Environment, 2008, 42(3), 568-581.

116 M. A. Dreyfus and M. V. Johnston, Aerosol Science and Technology, 2008, 42(1), 18-27. 
117 W. S. Wu and T. Wang, Atmospheric Environment, 2007, 41(26), 5442-5451.

118 I. Trebs, M. O. Andreae, W. Elbert, O. L. Mayol-Bracero, L. L. Soto-Garcia, Y. Rudich, A. H. Falkovich, W. Maenhaut, P. Artaxo, R. Otjes and J. Slanina, Aerosol Science and Technology, 2008, 42(4), 255-269.

119 R. Aguilar-Martinez, R. Greenwood, G. A. Mills, B. Vrana, M. A. PalaciosCorvillo and M. M. Gomez-Gomez, International Journal of Environmental Analytical Chemistry, 2008, 88(2), 75-90.

120 P. S. Tonello, A. H. Rosa, C. H. Abreu and A. A. Menegario, Anal. Chim. Acta, 2007, 598(1), 162-168.

121 D. D. Richardson and J. A. Caruso, Analytical and Bioanalytical Chemistry, 2007, 388(4), 809-823.

122 D. D. Richardson and J. A. Caruso, Analytical and Bioanalytical Chemistry, 2007, 389(3), 679-682.

123 J. Ellis, M. Shah, K. M. Kubachka and J. A. Caruso, Journal of Environmental Monitoring, 2007, 9(12), 1329-1336.

124 M. Popp, S. Hann, A. Mentler, M. Fuerhacker, G. Stingeder and G. Koellensperger, Analytical and Bioanalytical Chemistry, 2008, 391(2), 695699.

125 A. Gonzaez-Gago, J. M. Marchante-Gayo and J. I. G. Alonso, Journal of Analytical Atomic Spectrometry, 2007, 22(9), 1138-1144.

126 H. X. Yang, W. Liu, B. Li, H. J. Zhang, X. D. Liu and D. Y. Chen, Geostandards and Geoanalytical Research, 2007, 31(4), 345-351.

127 W. Liu, H. X. Yang, B. Li, D. Y. Chen and H. J. Zhang, Chin. J. Anal. Chem., 2007, 35(4), 571-574.

128 Z. L. Chen, M. Megharaj and R. Naidu, Talanta, 2007, 72(5), 1842-1846.

129 R. E. Wolf, J. M. Morrison and M. B. Goldhaber, Journal of Analytical Atomic Spectrometry, 2007, 22(9), 1051-1060.

130 G. Heltai, B. Feher and M. Horvath, Chem. Pap., 2007, 61(6), 438-445.

131 N. Campillo, R. Penalver, M. Hernandez-Cordoba, C. Perez-Sirvent and M. J. Martinez-Sanchez, J. Chromatogr. A, 2007, 1165(1-2), 191-199.

132 Z. L. Chen, W. H. Wang, M. Mallavarapu and R. Naidu, Spectrochimica Acta Part B-Atomic Spectroscopy, 2008, 63(1), 69-75.

133 J. Darrouzes, M. Bueno, S. Simon, F. Pannier and M. Potin-Gautier, Talanta, 2008, 75(2), 362-368.

134 B. Planer-Friedrich, J. London, R. B. McCleskey, D. K. Nordstrom and D. Wallschlager, Environ. Sci. Technol., 2007, 41(15), 5245-5251.

135 D. Wallschlager and J. London, Environmental Science \& Technology, 2008, 42(1), 228-234.

136 Y. Morita, T. Kobayashi, T. Kuroiwa and T. Narukawa, Talanta, 2007, 73(1), 81-86.

137 M. R. Webb, F. J. Andrade and G. M. Hieftje, Analytical Chemistry, 2007, 79(20), 7807-7812.

138 M. R. Webb, F. J. Andrade and G. M. Hieftje, Analytical Chemistry, 2007, 79(20), 7899-7905.

139 A. S. Ribeiro, M. A. Vieira, S. Willie and R. E. Sturgeon, Analytical and Bioanalytical Chemistry, 2007, 388(4), 849-857.

140 H. Matusiewicz and M. Krawczyk, Journal of Analytical Atomic Spectrometry, 2008, 23(1), 43-53.

141 Y. L. Yu, Z. Du and J. H. Wang, Journal of Analytical Atomic Spectrometry, 2007, 22(6), 650-656. 
142 M. Colon, M. Iglesias, M. Hidalgo and J. L. Todoli, Journal of Analytical Atomic Spectrometry, 2008, 23(3), 416-418.

143 M. Colon, M. Iglesias and M. Hidalgo, Spectroc. Acta Pt. B-Atom. Spectr., 2007, 62(5), 470-475.

144 C. B. Zheng, L. Wu, Q. Ma, Y. Lv and X. D. Hou, Journal of Analytical Atomic Spectrometry, 2008, 23(4), 514-520.

145 C. F. Han, C. B. Zheng, J. Wang, G. L. Cheng, Y. Lv and X. D. Hou, Analytical and Bioanalytical Chemistry, 2007, 388(4), 825-830.

146 J. A. Perez-Serradilla and M. D. L. de Castro, Analytical and Bioanalytical Chemistry, 2007, 389(5), 1541-1547.

147 J. A. Perez-Serradilla and M. D. L. de Castro, Anal. Chim. Acta, 2007, 594(1), 69-74.

148 E. Margui, C. Fontas, K. Van Meel, R. Van Grieken, I. Queralt and M. Hidalgo, Analytical Chemistry, 2008, 80(7), 2357-2364.

149 N. Elwaer and H. Hintelmann, Analytical and Bioanalytical Chemistry, 2007, 389(6), 1889-1899.

150 H. Tazoe, H. Obata and T. Gamo, Journal of Analytical Atomic Spectrometry, 2007, 22(6), 616-622.

151 M. Grotti and R. Frache, Journal of Analytical Atomic Spectrometry, 2007, 22(12), 1481-1487.

152 Z. L. Chen, M. Megharaj and R. Naidu, Talanta, 2007, 73(5), 948-952.

153 W. T. Y. Mohamed, Optica Applicata, 2007, 37(1-2), 5-19.

154 S. L. Lui, Y. Godwal, M. T. Taschuk, Y. Y. Tsui and R. Fedosejevs, Analytical Chemistry, 2008, 80(6), 1995-2000.

155 Z. J. Chen, H. K. Li, F. Zhao and R. H. Li, Journal of Analytical Atomic Spectrometry, 2008, 23(6), 871-875.

156 O. Rienitz, D. Schiel, B. Guttler, M. Koch and U. Borchers, Accreditation and Quality Assurance, 2007, 12(12), 615-622.

157 S. Duta, P. Robouch, L. Barbu and P. Taylor, Spectroc. Acta Pt. B-Atom. Spectr., 2007, 62(4), 337-343.

158 V. Pino, I. Hernandez-Martin, J. H. Ayala, V. Gonzalez and A. M. Afonso, Analytical Letters, 2007, 40(16-18), 3322-3342.

159 A. Sabarudin, O. Noguchi, M. Oshima, K. Higuchi and S. Motomizu, Microchimica Acta, 2007, 159(3-4), 341-348.

160 A. Sabarudin, N. Lenghor, M. Oshima, L. Hakim, T. Takayanagi, Y. H. Gao and S. Motomizu, Talanta, 2007, 72(5), 1609-1617.

161 Y. Y. Jiang, Y. W. Wu, J. F. Liu, X. Q. Xia and D. Wang, Microchimica Acta, 2008, 161(1-2), 137-142.

162 C. Z. Huang, B. Hu and Z. C. Jiang, Spectroc. Acta Pt. B-Atom. Spectr., 2007, 62(5), 454-460.

163 Z. H. Liu, F. Q. Zhou, F. M. Jiang, R. H. Huang, L. Yang and L. Z. Zhou, Spectroscopy and Spectral Analysis, 2008, 28(2), 456-459.

164 L. Elci, D. Sahan, A. Basaran and M. Soylak, Environ. Monit. Assess., 2007, 132(1-3), 331-338.

165 H. Wu, B. X. Du and C. Fang, Analytical Letters, 2007, 40(14), 2772-2782.

166 L. Xia, Y. Wu and B. Hu, Journal of Mass Spectrometry, 2007, 42(6), 803810.

167 A. Ali and A. R. Ghaderi, J. Hazard. Mater., 2007, 148(1-2), 319-325.

168 H. Wu, C. Fang, B. X. Du and C. C. Zhao, Microchimica Acta, 2008, 160(12), 173-178. 
169 A. N. Anthemidis and C. P. P. Karapatouchas, Microchimica Acta, 2008, 160(4), 455-460.

170 A. A. Ensafi and A. Z. Shiraz, Journal of the Brazilian Chemical Society, 2008, 19(1), 11-17.

171 J. P. Xiao, Q. X. Zhou and H. H. Bai, Journal of Environmental SciencesChina, 2007, 19(10), 1266-1271.

172 M. L. Chen, Y. Tian and J. H. Wang, Journal of Analytical Atomic Spectrometry, 2008, 23(6), 876-880.

173 Q. Fu, L. M. Yang and Q. Q. Wang, Spectroscopy Letters, 2007, 40(3), 547557.

174 D. S. Park and H. S. Choi, Bull. Korean Chem. Soc., 2007, 28(8), 1375-1382.

175 E. Buyuktuncel, N. Satiroglu, A. Denizli and S. Bektas, Fresenius Environmental Bulletin, 2008, 17(4), 467-477.

176 F. Z. Xie, X. C. Lin, X. P. Wu and Z. H. Xie, Talanta, 2008, 74(4), 836-843.

177 M. Tuzen, K. O. Saygi and M. Soylak, Journal of Hazardous Materials, 2008, 152(2), 632-639.

178 H. F. Maltez, M. A. Vieira, A. S. Ribeiro, A. J. Curtius and E. Carasek, Talanta, 2008, 74(4), 586-592.

179 S. Tokahoglu, V. Cetin and S. Kartal, Chemia Analityczna, 2008, 53(2), $263-$ 276.

180 A. Gundogdu, C. Duran, H. B. Senturk, L. Elci and M. Soylak, Acta Chimica Slovenica, 2007, 54(2), 308-316.

181 V. N. Bulut, A. Gundogdu, C. Duran, H. B. Senturk, M. Soylak, L. Elci and M. Tufekci, J. Hazard. Mater., 2007, 146(1-2), 155-163.

182 G. Venkatesh and A. K. Singh, Separation Science and Technology, 2007, 42(15), 3429-3446.

183 C. Z. Huang, Z. C. Jiang and B. Hu, Talanta, 2007, 73(2), 274-281.

184 M. Ghaedi, F. Ahmadi and M. Soylak, J. Hazard. Mater., 2007, 147(1-2), 226-231.

185 S. Z. Chen, M. F. Mao, D. B. Lu and Z. Wang, Spectrochimica Acta Part BAtomic Spectroscopy, 2007, 62(11), 1216-1221.

186 J. S. Suleiman, B. Hu, X. L. Pu, C. Z. Huang and Z. C. Jiang, Microchimica Acta, 2007, 159(3-4), 379-385.

187 A. J. de Blas, M. C. Alonso, A. Garcia-Sanchez and E. Alvarez-Ayuso, Communications in Soil Science and Plant Analysis, 2007, 38(15-16), 20912101.

188 Q. He, X. J. Chang, H. Zheng, N. Jiang and X. Y. Wang, International Journal of Environmental Analytical Chemistry, 2008, 88(6), 373-384.

189 N. Zhang, J. S. Suleiman, M. He and B. Hu, Talanta, 2008, 75(2), 536-543.

190 S. H. Ahmadi, A. M. H. Shabani, S. Dadfarnia and M. Taei, Turkish Journal of Chemistry, 2007, 31(2), 191-199.

191 A. M. Yusof, C. H. Chia and A. K. H. Wood, Journal of Radioanalytical and Nuclear Chemistry, 2007, 273(3), 533-538.

192 V. N. Bulut, C. Duran, M. Tufekci, L. Elci and M. Soylak, J. Hazard. Mater., 2007, 143(1-2), 112-117.

193 I. Narin, A. Kars and M. Soylak, Journal of Hazardous Materials, 2008, 150(2), 453-458.

194 M. Tuzen and M. Soylak, J. Hazard. Mater., 2007, 147(1-2), 219-225.

195 K. O. Saygi, M. Tuzen, M. Soylak and L. Elci, Journal of Hazardous Materials, 2008, 153(3), 1009-1014. 
196 C. Duran, M. Soylak, V. N. Bulut, A. Gundogdu, M. Tufekci, L. Elcid and H. B. Senturk, Journal of the Chinese Chemical Society, 2007, 54(3), 625-634.

197 Y. M. Cui, X. J. Chang, X. B. Zhu, H. X. Luo, Z. Hu, X. J. Zou and Q. He, Microchemical Journal, 2007, 87(1), 20-26.

198 A. Moghimi, Chinese Journal of Chemistry, 2007, 25(11), 1663-1668.

199 A. Moghimi, Chinese Journal of Chemistry, 2007, 25(12), 1842-1848.

200 Y. N. Lee and H. S. Choi, Journal of Analytical Chemistry, 2007, 62(9), 845851.

201 M. Imamoglu and V. Gunes, Instrumentation Science \& Technology, 2008, 36(1), 105-116.

202 M. Ghaedi, F. Ahmadi, Z. Tavakoli, M. Montazerozohori, A. Kharlmohammadi and M. Soylak, Journal of Hazardous Materials, 2008, 152(3), 1248-1255.

203 P. Hashemi, H. Hassanvand and H. Naeimi, Collection of Czechoslovak Chemical Communications, 2007, 72(7), 908-916.

204 L. Hakim, A. Sabarudin, K. Oshita, M. Oshima and S. Motomizu, Talanta, 2008, 74(4), 977-985.

205 A. H. Ei-Sheikh, J. A. Sweileh and Y. S. Al-Degs, Analytica Chimica Acta, 2007, 604(2), 119-126.

206 G. Khayatian and S. Pouzesh, Journal of the Iranian Chemical Society, 2007, 4(4), 490-496.

207 Y. L. Yu, Z. Du, M. L. Chen and J. H. Wang, Journal of Analytical Atomic Spectrometry, 2007, 22(7), 800-806.

208 X. G. Ma, B. Huang and M. Q. Cheng, Rare Metals, 2007, 26(6), 541-546.

209 Q. Wu, X. J. Chang, Q. He, Y. H. Zhai, Y. M. Cui and X. P. Huang, International Journal of Environmental Analytical Chemistry, 2008, 88(4), 245-254.

210 L. Escudero, R. A. Gil, J. A. Gasquez, R. A. Olsina and L. D. Martinez, Atomic Spectroscopy, 2008, 29(1), 21-26.

211 S. Dadfarnia, A. M. H. Shabani, A. A. Jafari and Z. Saadat, Chemia Analityczna, 2007, 52(5), 791-799.

212 Q. X. Zhou, H. H. Bai and J. P. Xiao, Atomic Spectroscopy, 2007, 28(4), 150 155.

213 R. S. Amais, J. S. Ribeiro, M. G. Segatelli, I. V. P. Yoshida, P. O. Luccas and C. R. T. Tarley, Separation and Purification Technology, 2007, 58(1), 122128.

214 C. E. Dogan and G. Akcin, Analytical Letters, 2007, 40(13), 2524-2543.

215 R. Liu and P. Liang, Journal of Hazardous Materials, 2008, 152(1), 166-171.

216 R. S. Praveen, G. R. K. Naidu and T. P. Rao, Analytica Chimica Acta, 2007, 600(1-2), 205-213.

217 Q. Fu, L. M. Yang and Q. Q. Wang, Talanta, 2007, 72(4), 1248-1254.

218 K. Kargosha, N. Shokoufi and J. Azad, Atomic Spectroscopy, 2007, 28(5), 171-177.

219 K. Jitmanee, N. Teshima, T. Sakai and K. Grudpan, Talanta, 2007, 73(2), 352357.

220 J. Pedro, J. Stripekis, A. Bonivardi and M. Tudino, Spectrochimica Acta Part B-Atomic Spectroscopy, 2008, 63(1), 86-91.

221 C. Huang and B. Hu, Journal of Separation Science, 2008, 31(4), 760-767.

222 T. Asadoulahi, S. Dadfarnia and A. M. H. Shabani, Journal of the Brazilian Chemical Society, 2007, 18(7), 1353-1359. 
223 S. Dadfarnia, T. Assadollahi and A. M. H. Shabani, J. Hazard. Mater., 2007, 148(1-2), 446-452.

224 K. Oshita, K. Seo, A. Sabarudin, M. Oshima, T. Takayanagi and S. Motomizu, Analytical and Bioanalytical Chemistry, 2008, 390(7), 1927-1932.

225 R. A. Gil, S. N. Goyanes, G. Polla, P. Smichowski, R. A. Olsina and L. D. Martinez, Journal of Analytical Atomic Spectrometry, 2007, 22(10), 12901295.

226 N. Pourreza and H. Barisami, Chem. Anal., 2007, 52(4), 597-604.

227 R. Santos, M. J. Canto Machado and L. Cortez, Geostandards and Geoanalytical Research, 2008, 32(2), 181-191.

228 J. L. Manzoori, H. Abdolmohammad-Zadeh and M. Amjadi, J. Hazard. Mater., 2007, 144(1-2), 458-463.

229 A. Beiraghi and S. Babaee, Analytica Chimica Acta, 2008, 607(2), 183-190.

230 L. A. Portugal, H. S. Ferreira, W. N. L. dos Santos and S. L. C. Ferreira, Microchemical Journal, 2007, 87(1), 77-80.

231 M. A. Bezerra, S. M. D. Maeda, E. P. Oliveira, M. D. B. de Carvalho and R. E. Santelli, Spectrochimica Acta Part B-Atomic Spectroscopy, 2007, 62(9), 985-991.

232 Y. Yamini, M. Faraji, S. Shariati, R. Hassani and M. Ghambarian, Analytica Chimica Acta, 2008, 612(2), 144-151.

233 M. Ghaedi, A. Shokrollahi, F. Ahmadi, H. R. Rajabi and M. Soylak, Journal of Hazardous Materials, 2008, 150(3), 533-540.

234 P. Liang and H. B. Sang, Journal of Hazardous Materials, 2008, 154(1-3), 1115-1119.

235 Y. Ebihara, T. Shimizu, K. Jinno and N. Uehara, Bunseki Kagaku, 2007, 56(9), 737-743.

236 P. Biparva and M. R. Hadjmohammadi, Acta Chimica Slovenica, 2007, 54(4), 805-810.

237 N. Goudarzi, Journal of the Brazilian Chemical Society, 2007, 18(7), 13481352.

238 K. Suvardhan, D. Rekha, K. S. Kumar, P. R. Prasad, J. D. Kumar, B. Jayaraj and P. Chiranjeevi, J. Hazard. Mater., 2007, 144(1-2), 126-131.

239 J. L. Manzoori and H. Abdolmohammad-Zadeh, Acta Chimica Slovenica, 2007, 54(2), 378-384.

240 B. K. Priya, P. Subrahmanayam, K. Suvardhan, K. S. Kumar, D. Rekha, A. V. Rao, G. C. Rao and P. Chiranjeevi, J. Hazard. Mater., 2007, 144(1-2), 152158.

241 F. Bai and Z. F. Fan, Microchimica Acta, 2007, 159(3-4), 235-240.

242 Y. J. Li, B. Hu, M. He and G. Q. Xiang, Water Research, 2008, 42(4-5), $1195-$ 1203.

243 N. N. Meeravali and S. J. Jiang, Journal of Analytical Atomic Spectrometry, 2008, 23(4), 555-560.

244 Z. Arslan and J. F. Tyson, Microchimica Acta, 2008, 160(1-2), 219-225.

245 J. Scancar, M. Zupancic and R. Milacic, Water Air Soil Pollut., 2007, 185(14), 121-129.

246 K. L. Mandiwana, Talanta, 2008, 74(4), 736-740.

247 C. G. Yuan, B. He, E. L. Gao, J. X. Lu and G. B. Jiang, Microchimica Acta, 2007, 159(1-2), 175-182.

248 K. A. Mir, A. Rutter, I. Koch, P. Smith, K. J. Reimer and J. S. Poland, Talanta, 2007, 72(4), 1507-1518. 
249 M. Zemberyova, R. Jankovic, I. Hagarova and H. M. Kuss, Spectroc. Acta Pt. B-Atom. Spectr., 2007, 62(5), 509-513.

250 J. Kubova, P. Matus, M. Bujdos, I. Hagarova and J. Medved, Talanta, 2008, 75(4), 1110-1122.

251 M. B. Arain, T. G. Kazi, M. K. Jamah, N. Jalbani, H. I. Afridi and J. A. Baig, Journal of Hazardous Materials, 2008, 154(1-3), 998-1006.

252 M. P. Beeston, H. J. Glass, J. T. van Elteren and Z. Slejkovec, Analytica Chimica Acta, 2007, 599(2), 264-270.

253 A. R. Turker, Clean-Soil Air Water, 2007, 35(6), 548-557.

254 N. Forsgard, P. Sjoberg, D. Bylund, M. Andersson and J. Pettersson, Journal of Analytical Atomic Spectrometry, 2007, 22(11), 1397-1402.

255 S. K. V. Yathavakilla, M. Fricke, P. A. Creed, D. T. Heitkemper, N. V. Shockey, C. Schwegel, J. A. Caruso and J. T. Creed, Analytical Chemistry, 2008, 80(3), 775-782.

256 K. Bluemlein, A. Raab, A. A. Meharg, J. M. Charnock and J. Feldmann, Analytical and Bioanalytical Chemistry, 2008, 390(7), 1739-1751.

257 B. B. M. Sadi, A. P. Vonderheide, J. M. Gong, J. I. Schroeder, J. R. Shann and J. A. Caruso, Journal of Chromatography B-Analytical Technologies in the Biomedical and Life Sciences, 2008, 861(1), 123-129.

258 C. Y. Kuo, S. J. Jiang and A. C. Sahayam, Journal of Analytical Atomic Spectrometry, 2007, 22(6), 636-641.

259 K. Polec-Pawlak, R. Ruzik, E. Lipiec, M. Ciurzynska and H. Gawronska, Journal of Analytical Atomic Spectrometry, 2007, 22(8), 968-972.

260 E. M. Krupp, B. F. Milne, A. Mestrot, A. A. Meharg and J. Feldmann, Analytical and Bioanalytical Chemistry, 2008, 390(7), 1753-1764.

261 S. Yoshida, Y. Muramatsu, S. Katou and H. Sekimoto, Journal of Radioanalytical and Nuclear Chemistry, 2007, 273(1), 211-214.

262 K. Telford, W. Maher, F. Krikowa and S. Foster, Journal of Environmental Monitoring, 2008, 10(1), 136-140.

263 A. J. Bednar, J. E. Mirecki, L. S. Inouye, L. E. Winfield, S. L. Larson and D. B. Ringelberg, Talanta, 2007, 72(5), 1828-1832.

264 S. P. Han, W. E. Gan and Q. D. Su, Talanta, 2007, 72(4), 1481-1486.

265 F. S. Rojas, C. B. Ojeda and J. M. C. Pavon, Talanta, 2007, 72(3), 951-956.

266 N. Ertas, Z. Arslan and J. F. Tyson, Journal of Analytical Atomic Spectrometry, 2008, 23(2), 223-228.

267 L. Kekedy-Nagy, Y. Jun and E. Darvasi, Journal of Biochemical and Biophysical Methods, 2008, 70(6), 1234-1239.

268 L. Husakova, T. Cernohorsky, J. Sramkova, K. Hubackova and I. Dolezalova, Analytica Chimica Acta, 2008, 614(1), 38-45.

269 I. Lopez-Garcia, R. E. Rivas and M. Hernandez-Cordoba, Analytical and Bioanalytical Chemistry, 2008, 391(4), 1469-1474.

270 C. S. Nomura, D. P. Intima, P. V. Oliveira, I. A. Ruffini and F. J. Krug, Analytical and Bioanalytical Chemistry, 2008, 391(4), 1135-1137.

271 O. Cankur and O. Y. Ataman, Journal of Analytical Atomic Spectrometry, 2007, 22(7), 791-799.

272 P. Wu, Y. Gao, G. Cheng, W. Yang, Y. Lv and X. Hou, Journal of Analytical Atomic Spectrometry, 2008, 23(5), 752-757.

273 D. B. Lkiewicz, A. Kanecka-Hanc and H. Gramowska, Central European Journal of Chemistry, 2007, 5(4), 1148-1157. 
274 E. J. dos Santos, A. B. Herrmann, V. L. A. Frescura, B. Welz and A. J. Curtius, Analytical and Bioanalytical Chemistry, 2007, 388(4), 863-868.

275 P. Masson, M. Dauthieu, F. Trolard and L. Denaix, Spectroc. Acta Pt. B-Atom. Spectr., 2007, 62(3), 224-230.

276 I. Hubova, M. Hola, J. Pinkas and V. Kanicky, Journal of Analytical Atomic Spectrometry, 2007, 22(10), 1238-1243.

277 G. L. Donati, J. Gu, J. A. Nobrega, C. P. Calloway and B. T. Jones, Journal of Analytical Atomic Spectrometry, 2008, 23(3), 361-366.

278 N. Campillo, R. Penalver and M. Hernandez-Cordoba, Journal of Chromatography A, 2007, 1173(1-2), 139-145.

279 Z. L. Zhu, J. X. Liu, S. C. Zhang, X. Na and X. R. Zhang, Analytica Chimica Acta, 2008, 607(2), 136-141.

280 M. N. M. Reyes, M. L. Cervera, R. C. Campos and M. de la Guardia, Talanta, 2008, 75(3), 811-816.

281 B. Fernandez, F. Claverie, C. Pecheyran and O. F. X. Donard, Journal of Analytical Atomic Spectrometry, 2008, 23(3), 367-377.

282 M. S. Jimenez, M. T. Gomez and J. R. Castillo, Talanta, 2007, 72(3), 11411148 .

283 J. V. Cizdziel, M. E. Ketterer, D. Farmer, S. H. Faller and V. F. Hodge, Analytical and Bioanalytical Chemistry, 2008, 390(2), 521-530.

284 A. Polatajko, M. Azzolini, I. Feldmann, T. Stuezel and N. Jakubowski, Journal of Analytical Atomic Spectrometry, 2007, 22(8), 878-887.

285 R. A. Diaz-Bone and M. Hitzke, Journal of Analytical Atomic Spectrometry, 2008, 23(6), 861-870.

286 S. Garcia-Ruiz, M. Moldovan and J. I. G. Alonso, J. Chromatogr. A, 2007, 1149(2), 274-281.

287 S. Garcia-Ruiz, M. Moldovan and J. I. G. Alonso, Journal of Analytical Atomic Spectrometry, 2008, 23(1), 84-93.

288 J. S. Becker, K. Fullner, U. D. Seeling, G. Fornalczyk and A. J. Kuhn, Analytical and Bioanalytical Chemistry, 2008, 390(2), 571-578.

289 I. G. Wiederhold, N. Teutsch, S. M. Kraemer, A. N. Halliday and R. Kretzschmar, Soil Science Society of America Journal, 2007, 71(6), 18401850.

290 R. Santos, M. J. C. Machado, I. Ruiz, K. Sato and M. Vasconcelos, Journal of Analytical Atomic Spectrometry, 2007, 22(7), 783-790.

291 E. Margui, M. Iglesias, I. Queralt and M. Hidalgo, Talanta, 2007, 73(4), 700709.

292 D. De Muynck, C. Cloquet and F. Vanhaecke, Journal of Analytical Atomic Spectrometry, 2008, 23(1), 62-71.

293 F. Pointurier, P. Hemet and A. Hubert, Journal of Analytical Atomic Spectrometry, 2008, 23(1), 94-102.

294 V. N. Epov, R. D. Evans, J. Zheng, O. F. X. Donard and M. Yamada, Journal of Analytical Atomic Spectrometry, 2007, 22(9), 1131-1137.

295 C. Greis, S. Karlsson, A. Duker, H. Pettersson and B. Allard, Journal of Radioanalytical and Nuclear Chemistry, 2008, 275(1), 55-70.

296 Z. X. Guo, Q. T. Cai and Z. Yang, Rapid Commun. Mass Spectrom., 2007, 21(10), 1606-1612.

297 M. D'Elia, G. Gianfrate, G. Quarta, L. Giotta, G. Giancane and L. Calcagnile, Radiocarbon, 2007, 49(2), 201-210. 
298 N. E. Whitehead, S. Endo, K. Tanaka, T. Takatsuji, M. Hoshi, S. Fukutani, R. G. Ditchburn and A. Zondervan, Journal of Environmental Radioactivity, 2008, 99(2), 260-270.

299 D. P. Child, M. A. C. Hotchkis and M. L. Williams, Journal of Analytical Atomic Spectrometry, 2008, 23(5), 765-768.

300 T. Suzuki, S. Banba, T. Kitamura, S. Kabuto, K. Isogai and H. Amano, Nucl. Instrum. Methods Phys. Res. Sect. B-Beam Interact. Mater. Atoms, 2007, 259(1), 370-373.

301 H. Matsuzaki, Y. Muramatsu, K. Kato, M. Yasumoto and C. Nakano, Nucl. Instrum. Methods Phys. Res. Sect. B-Beam Interact. Mater. Atoms, 2007, 259(1), 721-726.

302 N. Idris, K. Kagawa, F. Sakan, K. Tsuyuki and S. Miura, Applied Spectroscopy, 2007, 61(12), 1344-1351.

303 V. Lazic, I. Rauschenbach, S. Jovicevic, E. K. Jessberger, R. Fantoni and M. Di Fino, Spectrochimica Acta Part B-Atomic Spectroscopy, 2007, 62(12), 1546-1556.

304 M. Gallova, J. Kaiser, K. Novotny, O. Samek, L. Reale, R. Malina, K. Palenikova, M. Liska, V. Cudek, V. Kanicky, V. Otruba, A. Poma and A. Tucci, Spectrochimica Acta Part B-Atomic Spectroscopy, 2007, 62(12), 15971605.

305 M. Bossu, Z. Q. Hao, M. Baudelet, J. Yu, Z. Zhang and J. Zhang, Chinese Physics Letters, 2007, 24(12), 3466-3468.

306 G. Tylko, J. Mesjasz-Przybylowicz and W. J. Przybylowicz, Nucl. Instrum. Methods Phys. Res. Sect. B-Beam Interact. Mater. Atoms, 2007, 260(1), 141148.

307 R. Siegele, A. G. Kachenko, N. P. Bhatia, Y. D. Wang, M. Ionescu, B. Singh, A. J. M. Baker and D. D. Cohen, X-Ray Spectrometry, 2008, 37(2), 133-136.

308 K. Tsutsumimoto and K. Tsuji, X-Ray Spectrometry, 2007, 36(5), 324-327.

309 F. Meirer, G. Pepponi, C. Streli, P. Wobrauschek, V. G. Mihucz, G. Zaray, V. Czech, J. A. C. Broekaert, U. E. A. Fittschen and G. Falkenberg, X-Ray Spectrometry, 2007, 36(6), 408-412.

310 A. A. Meharg, E. Lombi, P. N. Williams, K. G. Scheckel, J. Feldmann, A. Raab, Y. G. Zhu and R. Islam, Environmental Science \& Technology, 2008, 42(4), 1051-1057.

311 A. Voegelin, F. A. Weber and R. Kretzschmar, Geochimica Et Cosmochimica Acta, 2007, 71(23), 5804-5820.

312 N. N. Meeravali and S. J. Jiang, Journal of Analytical Atomic Spectrometry, 2008, 23(6), 854-860.

313 M. A. Bezerra, A. R. A. Nogueira, S. G. Lemos and S. L. C. Ferreira, International Journal of Environmental Analytical Chemistry, 2008, 88(2), 131-140.

314 X. S. Zhu, Z. Zhu and S. Wu, Microchimica Acta, 2008, 161(1-2), 143-148.

315 F. A. C. Amorim and M. A. Bezerra, Microchimica Acta, 2007, 159(1-2), $183-$ 189.

316 B. Puzio, B. Mikula and B. Feist, Microchimica Acta, 2008, 160(1-2), 197201.

317 M. Dogru, R. Gul-Guven and S. Erdogan, Journal of Hazardous Materials, 2007, 149(1), 166-173.

318 V. A. Lemos, C. G. Novaes, A. D. Lima and D. R. Vieira, Journal of Hazardous Materials, 2008, 155(1-2), 128-134. 
319 S. Baytak, Acta Chimica Slovenica, 2007, 54(2), 385-391.

320 S. Dadfarnia, M. Talebi, A. M. H. Shabani and Z. Beni, Croatica Chemica Acta, 2007, 80(1), 17-23.

321 D. Mendil, M. Tuzen, C. Usta and M. Soylak, Journal of Hazardous Materials, 2008, 150(2), 357-363.

322 D. Mendil, M. Tuzen and M. Soylak, Journal of Hazardous Materials, 2008, 152(3), 1171-1178.

323 M. A. Bezerra, W. N. L. dos Santos, V. A. Lemos, M. Korn and S. L. C. Ferreira, J. Hazard. Mater., 2007, 148(1-2), 334-339.

324 S. Seyhan, M. Merdivan, N. Demirel and H. Hosgoren, Microchimica Acta, 2008, 161(1-2), 87-93.

325 E. Kenduzler, O. Yalcinkaya, S. Baytak and A. R. Turker, Microchimica Acta, 2008, 160(4), 389-395.

326 X. B. Zhu, X. J. Chang, Y. M. Cui, X. J. Zou, D. Yang and Z. Hu, Microchemical Journal, 2007, 86(2), 189-194.

327 N. Zhang, B. Hu and C. Z. Huang, Anal. Chim. Acta, 2007, 597(1), 12-18.

328 X. B. Zhu, D. Yang, X. Chang, Y. M. Cui, Z. Hu and X. Zou, Microchimica Acta, 2008, 161(1-2), 115-122.

329 S. Baytak, A. Kocyigit and A. R. Turker, Clean-Soil Air Water, 2007, 35(6), 607-611.

330 A. A. Ensafi and A. Z. Shiraz, Journal of Hazardous Materials, 2008, 150(3), 554-559.

331 J. Fan, C. L. Wu, H. Z. Xu, J. J. Wang and C. Y. Peng, Talanta, 2008, 74(4), 1020-1025.

332 V. Ljubomirove and R. Djingova, Analytica Chimica Acta, 2008, 614(2), 119126.

333 S. Z. Chen, M. F. Xiao, D. B. Lu and X. L. Zhan, Analytical Letters, 2007, 40(11), 2105-2115.

334 N. Zhang, C. Huang and B. Hu, Anal. Sci., 2007, 23(8), 997-1002.

335 F. A. Aydin and M. Soylak, Talanta, 2007, 73(1), 134-141.

336 M. Soylak and M. Tuzen, Journal of Hazardous Materials, 2008, 152(2), 656661.

337 M. Soylak, B. Kaya and M. Tuzen, J. Hazard. Mater., 2007, 147(3), 832-837.

338 Z. Varga, G. Suranyi, N. Vajda and Z. Stefanka, Journal of Radioanalytical and Nuclear Chemistry, 2007, 274(1), 87-94.

339 M. Valladon, Geostandards and Geoanalytical Research, 2007, 31(4), 395409.

340 K. P. Jochum, Geostandards and Geoanalytical Research, 2007, 31(4), 411448.

341 X. Q. Wang, Q. Zhang and G. H. Zhou, Geostandards and Geoanalytical Research, 2007, 31(4), 311-320.

342 J. Vogl, Journal of Analytical Atomic Spectrometry, 2007, 22(5), 475-492.

343 A. Botha, A. I. Barzev and J. L. Fischer, Journal of Analytical Atomic Spectrometry, 2007, 22(5), 578-581.

344 J. S. Kane, P. J. Potts, T. Meisel and M. Wiedenbeck, Geostandards and Geoanalytical Research, 2007, 31(3), 285-288.

345 J. S. Kane and P. J. Potts, Geostandards and Geoanalytical Research, 2007, 31(4), 361-378.

346 T. X. Gu, C. Y. Shi, W. Pu, W. D. Yan, M. Liu and M. C. Yan, Geostandards and Geoanalytical Research, 2007, 31(2), 125-132. 
347 A. J. B. Cotta and J. Enzweiler, Geostandards and Geoanalytical Research, 2008, 32(2), 231-235.

348 A. J. B. Cotta, J. Enzweiler, S. A. Wilson, C. A. Perez, A. J. R. Nardy and J. H. Larizzatti, Geostandards and Geoanalytical Research, 2007, 31(4), 379393.

349 P. Roy, V. Balaram, A. Kumar, M. Satyanarayanan and T. G. Rao, Geostandards and Geoanalytical Research, 2007, 31(3), 261-273.

350 S. Waheed, A. Rahman, N. Siddique and S. Ahmad, Geostandards and Geoanalytical Research, 2007, 31(2), 133-141.

351 M. Willbold, Journal of Analytical Atomic Spectrometry, 2007, 22(11), 13641372.

352 K. Abraham, S. Opfergelt, F. Fripiat, A. J. Cavagna, J. T. M. de Jong, S. F. Foley, L. Andre and D. Cardinal, Geostandards and Geoanalytical Research, 2008, 32(2), 193-202.

353 B. C. Reynolds, J. Aggarwal, L. Andre, D. Baxter, C. Beucher, M. A. Brzezinski, E. Engstrom, R. B. Georg, M. Land, M. J. Leng, S. Opfergelt, I. Rodushkin, H. J. Sloane, S. van den Boorn, P. Z. Vroon and D. Cardinal, Journal of Analytical Atomic Spectrometry, 2007, 22(5), 561-568.

354 J. Carignan and H. J. Wen, Chem. Geol., 2007, 242(3-4), 347-350.

355 D. Weis, B. Kieffer, D. Hanano, I. N. Silva, J. Barling, W. Pretorius, C. Maerschalk and N. Mattielli, Geochemistry Geophysics Geosystems, 2007, 8.

356 K. W. W. Sims, J. B. Gill, A. Dosseto, D. L. Hoffmann, C. C. Lundstrom, R. W. Williams, L. Ball, D. Tollstrup, S. Turner, J. Prytulak, J. J. G. Glessner, J. J. Standish and T. Elliott, Geostandards and Geoanalytical Research, 2008, 32(1), 65-91.

357 J. Prytulak, T. Elliott, D. L. Hoffmann and C. D. Coath, Geostandards and Geoanalytical Research, 2008, 32(1), 55-63.

358 T. Shinonaga, H. Aigner, D. Klose, P. Spinder, H. Froschl and D. Donohue, Geostandards and Geoanalytical Research, 2008, 32(1), 93-101.

359 F. Corfu, Chemical Geology, 2007, 244(1-2), 350-353.

360 J. Slama, J. Kosler, D. J. Condon, J. L. Crowley, A. Gerdes, J. M. Hanchar, M. S. A. Horstwood, G. A. Morris, L. Nasdala, N. Norberg, U. Schaltegger, B. Schoene, M. N. Tubrett and M. J. Whitehouse, Chemical Geology, 2008, 249(1-2), 1-35.

361 S. Klemme, S. Prowatke, C. Munker, C. W. Magee, Y. Lahaye, T. Zack, S. A. Kasemann, E. J. A. Cabato and B. Kaeser, Geostandards and Geoanalytical Research, 2008, 32(1), 39-54.

362 V. Chavagnac, J. A. Milton, D. R. H. Green, J. Breuer, O. Bruguier, D. E. Jacob, T. Jong, G. D. Kamenov, J. Le Huray, Y. Liu, M. R. Palmer, S. Pourtales, I. Roduhskin, A. Soldati, C. N. Trueman and H. Yuan, Analytica Chimica Acta, 2007, 599(2), 177-190.

363 B. Fernandez, F. Claverie, C. Pecheyran and O. F. X. Donard, Trac-Trends in Analytical Chemistry, 2007, 26(10), 951-966.

364 R. Freydier, F. Candaudap, F. Poitrasson, A. Arbouet, B. Chatel and B. Dupre, Journal of Analytical Atomic Spectrometry, 2008, 23(5), 702-710.

365 T. Hiratat and Y. Kon, Analytical Sciences, 2008, 24(3), 345-353.

366 J. J. Gonzalez, A. Fernandez, D. Oropeza, X. Mao and R. E. Russo, Spectrochimica Acta Part B-Atomic Spectroscopy, 2008, 63(2), 277-286.

367 I. Horn and F. von Blanckenburg, Spectroc. Acta Pt. B-Atom. Spectr., 2007, 62(4), 410-422. 
368 A. Y. Borisova, R. Freydier, M. Polve, S. Salvi, F. Candaudap and T. Aigouy, Geostandards and Geoanalytical Research, 2008, 32(2), 209-229.

369 J. Chmeleff, I. Horn, G. Steinhoefel and F. von Blanckenburg, Chemical Geology, 2008, 249(1-2), 155-166.

370 E. C. Hathorne, R. H. James, P. Savage and O. Alard, Journal of Analytical Atomic Spectrometry, 2008, 23(2), 240-243.

371 A. J. Fitzpatrick, T. K. Kyser, D. Chipley and D. Beauchemin, Journal of Analytical Atomic Spectrometry, 2008, 23(2), 244-248.

372 C. C. Wohlgemuth-Ueberwasser, C. Ballhaus, J. Berndt, V. S. N. Paliulionyte and T. Meisel, Contributions to Mineralogy and Petrology, 2007, 154(5), 607617.

373 S. Dewaele, P. Muchez and J. Hertogen, Geologica Belgica, 2007, 10(1-2), 109-119.

374 S. F. Boulyga, J. Heilmann, T. Prohaska and K. G. Heumann, Analytical and Bioanalytical Chemistry, 2007, 389(3), 697-706.

375 B. Stoll, K. P. Jochum, K. Herwig, M. Amini, M. Flanz, B. Kreuzburg, D. Kuzmin, M. Willbold and J. Enzweiler, Geostandards and Geoanalytical Research, 2008, 32(1), 5-26.

376 F. Nehring, D. E. Jacob, M. G. Barth and S. F. Foley, Microchimica Acta, 2008, 160(1-2), 153-163.

377 M. Resano, E. Garcia-Ruiz, M. A. Belarra, F. Vanhaecke and K. S. McIntosh, Trac-Trends Anal. Chem., 2007, 26(5), 385-395.

378 P. Z. Vroon, B. van der Wagt, J. M. Koornneef and G. R. Davies, Analytical and Bioanalytical Chemistry, 2008, 390(2), 465-476.

379 C. Paton, J. D. Woodhead, J. M. Hergt, D. Phillips and S. Shee, Geostandards and Geoanalytical Research, 2007, 31(4), 321-330.

380 Y. H. Yang, J. F. Sun, L. W. Xie, H. R. Fan and F. Y. Wu, Chinese Science Bulletin, 2008, 53(7), 1062-1070.

381 A. K. Souders and P. J. Sylvester, Journal of Analytical Atomic Spectrometry, 2008, 23(4), 535-543.

382 M. E. Lipschutz, S. F. Wolf, F. B. Culp and A. J. R. Kent, Anal. Chem., 2007, 79(12), 4249-4274.

383 G. E. Gehrels, V. A. Valencia and J. Ruiz, Geochemistry Geophysics Geosystems, 2008, 9.

384 H. L. Yuan, S. Gao, M. N. Dai, C. L. Zong, D. Gunther, G. H. Fontaine, X. M. Liu and C. Diwu, Chemical Geology, 2008, 247(1-2), 100-118.

385 J. L. Paquette and M. Tiepolo, Chem. Geol., 2007, 240(3-4), 222-237.

386 D. Chipley, P. A. Polito and T. K. Kyser, American Mineralogist, 2007, 92(11-12), 1925-1935.

387 G. M. Nowell, D. G. Pearson, S. W. Parman, A. Luguet and E. Hanski, Chemical Geology, 2008, 248(3-4), 394-426.

388 J. D. Woodhead, J. Hellstrom, J. M. Hergt, A. Greig and R. Maas, Geostandards and Geoanalytical Research, 2007, 31(4), 331-343.

389 D. Michaud, R. Leclerc and E. Proulx, Spectrochimica Acta Part B-Atomic Spectroscopy, 2007, 62(12), 1575-1581.

390 M. Gaft, I. Sapir-Sofer, H. Modiano and R. Stana, Spectrochimica Acta Part B-Atomic Spectroscopy, 2007, 62(12), 1496-1503.

391 T. Ctvrtnickova, L. M. Cabalin, J. Laserna and V. Kanicky, Spectrochimica Acta Part B-Atomic Spectroscopy, 2008, 63(1), 42-50. 
392 N. J. McMillan, R. S. Harmon, F. C. De Lucia and A. M. Miziolek, Spectrochimica Acta Part B-Atomic Spectroscopy, 2007, 62(12), 1528-1536.

393 S. Laville, M. Sabsabi and F. R. Doucet, Spectrochimica Acta Part B-Atomic Spectroscopy, 2007, 62(12), 1557-1566.

394 J. B. Sirven, B. Salle, P. Mauchien, J. L. Lacour, S. Maurice and G. Manhes, Journal of Analytical Atomic Spectrometry, 2007, 22(12), 1471-1480.

395 A. De Giacomo, M. Dell'Aglio, O. De Pascale, S. Longo and M. Capitelli, Spectrochimica Acta Part B-Atomic Spectroscopy, 2007, 62(12), 1606-1611.

396 L. A. Pereira, S. Borges, M. C. Castro, W. Borges, C. C. Windmoller and J. B. B. da Silva, Canadian Journal of Chemistry-Revue Canadienne De Chimie, 2008, 86(4), 312-316.

397 M. C. Barciela-Alonso, R. Varela-Vilela, E. Pena-Vazquez, A. BermejoBarrera and P. Bermejo-Barrera, Atomic Spectroscopy, 2007, 28(3), 102-107.

398 D. L. G. Borges, B. Welz and A. J. Curtius, Microchimica Acta, 2007, 159(12), 19-26.

399 Y. Y. Su, K. L. Xu, Y. Gao and X. D. Hou, Microchimica Acta, 2008, 160(12), 191-195.

400 D. P. Torres, M. A. Weira, A. S. Ribeiro and A. J. Curtius, Journal of the Brazilian Chemical Society, 2007, 18(4), 728-732.

401 M. S. Navarro, S. Andrade, H. Ulbrich, C. B. Gomes and V. A. V. Girardi, Geostandards and Geoanalytical Research, 2008, 32(2), 167-180.

402 M. Silva, K. Kyser, C. Oates and D. Beauchemin, Journal of Geochemical Exploration, 2007, 94(1-3), 30-42.

403 E. M. M. Flores, M. F. Mesko, D. P. Moraes, J. S. F. Pereira, P. A. Mello, J. S. Barin and G. Knapp, Analytical Chemistry, 2008, 80(6), 1865-1870.

404 V. Ettler, M. Mihaljevic, O. Sebek and Z. Nechutny, Chemosphere, 2007, 68(3), 455-463.

405 L. Qi, M. F. Zhou, C. Y. Wang and M. Sun, Geochemical Journal, 2007, 41(6), 407-414.

406 K. Shinotsuka and K. Suzuki, Analytica Chimica Acta, 2007, 603(2), 129-139.

407 R. Liu and P. Liang, Analytica Chimica Acta, 2007, 604(2), 114-118.

408 H. S. Refiker, M. Merdivan and R. S. Aygun, Separation Science and Technology, 2008, 43(1), 179-191.

409 A. M. Thomas and D. S. R. Murty, Atomic Spectroscopy, 2008, 29(2), 69-75.

410 M. Shamsipur and M. Ramezania, Talanta, 2008, 75(1), 294-300.

411 S. H. Chen, M. F. Xiao, D. B. Lu, Z. X. Hu and X. L. Zhan, Atomic Spectroscopy, 2007, 28(3), 90-94.

412 M. F. Xiao, S. Z. Chen, D. B. Lu and X. L. Zhan, Spectroscopy and Spectral Analysis, 2008, 28(2), 444-446.

413 D. Lariviere, D. K. Brownell, V. N. Epov, R. J. Cornett and R. D. Evans, Journal of Radioanalytical and Nuclear Chemistry, 2007, 273(2), 337-344.

414 B. Antizar-Ladislao, Environment International, 2008, 34(2), 292-308.

415 C. Dietz, J. Sanz, E. Sanz, R. Munoz-Olivas and C. Camara, J. Chromatogr. A, 2007, 1153(1-2), 114-129.

416 T. M. Namanic, R. Milacic and J. Scancar, International Journal of Environmental Analytical Chemistry, 2007, 87(9), 615-625.

417 P. N. Carvalho, L. F. Pinto, A. C. P. Basto and A. Vasconcelos, Microchemical Journal, 2007, 87(2), 147-153.

418 P. Konieczka, B. Sejeroe-Olsen, T. P. J. Linsinger and H. Schimmel, Analytical and Bioanalytical Chemistry, 2007, 388(4), 975-978. 
419 M. Uveges, L. Abranko and P. Fodor, Talanta, 2007, 73(3), 490-497.

420 P. Rodriguez-Gonzalez, M. Monperrus, J. I. G. Alonso, D. Amouroux and O. F. X. Donard, Journal of Analytical Atomic Spectrometry, 2007, 22(11), 13731382.

421 J. J. B. Nevado, R. C. R. Martin-Doimeadios, F. J. G. Bernardo and M. J. Moreno, Analytica Chimica Acta, 2008, 608(1), 30-37.

422 E. Bjorn, T. Larsson, L. Lambertsson, U. Skyllberg and W. Frech, Ambio, 2007, 36(6), 443-451.

423 B. Welz, D. L. G. Borges, M. G. R. Vale and U. Heitmann, Analytical and Bioanalytical Chemistry, 2007, 389(7-8), 2085-2095.

424 S. A. Rabb and J. W. Olesik, Spectrochimica Acta Part B-Atomic Spectroscopy, 2008, 63(2), 244-256.

425 K. Tagami and S. Uchida, Journal of Radioanalytical and Nuclear Chemistry, 2007, 273(1), 147-150.

426 K. Nakamura and Q. Chang, Geostandards and Geoanalytical Research, 2007, 31(3), 185-197.

427 A. Rowlan, T. B. Housh and J. A. Holcombe, Journal of Analytical Atomic Spectrometry, 2008, 23(2), 167-172.

428 P. Grinberg, S. Willie and R. E. Sturgeon, Journal of Analytical Atomic Spectrometry, 2007, 22(11), 1409-1414.

429 L. Skipperud, D. H. Oughton, L. S. Rosten, M. J. Wharton and J. P. Day, Journal of Environmental Radioactivity, 2007, 98(3), 251-263.

430 E. Ciceri, S. Recchia, C. Dossi, L. Yang and R. E. Sturgeon, Talanta, 2008, 74(4), 642-647.

431 T. I. Platzner, I. Segal and L. Halicz, Analytical and Bioanalytical Chemistry, 2008, 390(2), 441-450.

432 C. Cloquet, J. Carignan, M. F. Lehmann and F. Vanhaecke, Analytical and Bioanalytical Chemistry, 2008, 390(2), 451-463.

433 J. C. J. Petit, J. de Jong, L. Chou and N. Mattielli, Geostandards and Geoanalytical Research, 2008, 32(2), 149-166.

434 M. Rosner, L. Ball, B. Peucker-Ehrenbrink, J. Blusztajn, W. Bach and J. Erzinger, Geostandards and Geoanalytical Research, 2007, 31(2), 77-88.

435 N. Elwaer and H. Hintelmann, Journal of Analytical Atomic Spectrometry, 2008, 23(5), 733-743.

436 P. Galler, A. Limbeck, S. F. Boulyga, G. Stingeder, T. Hirata and T. Prohaska, Anal. Chem., 2007, 79(13), 5023-5029.

437 B. Gao, Y. Liu, K. Sun, X. R. Liang, P. Peng, G. Sheng and J. Fu, Analytica Chimica Acta, 2008, 612(1), 114-120.

438 D. N. Malinovskii, I. V. Rodyushkin and V. Ohlander, Geochemistry International, 2007, 45(4), 381-389.

439 A. J. Pietruszka and A. D. Reznik, International Journal of Mass Spectrometry, 2008, 270(1-2), 23-30.

440 G. M. Nowell, A. Luguet, D. G. Pearson and M. S. A. Horstwood, Chemical Geology, 2008, 248(3-4), 363-393.

441 D. Malinovsky, R. E. Sturgeon and L. Yang, Analytical Chemistry, 2008, 80(7), 2548-2555.

442 I. V. Chernyshev, A. V. Chugaev and K. N. Shatagin, Geochemistry International, 2007, 45(11), 1065-1076.

443 W. R. MacFarlane, T. K. Kyser and D. Chipley, Geochemistry-Exploration Environment Analysis, 2007, 7, 319-327. 
444 D. L. Hoffmann, J. Prytulak, D. A. Richards, T. Elliott, C. D. Coath, P. L. Smart and D. Scholz, International Journal of Mass Spectrometry, 2007, 264(2-3), 97-109.

445 A. Makishima, T. A. Chekol and E. Nakamura, Journal of Analytical Atomic Spectrometry, 2007, 22(11), 1383-1389.

446 L. Ball, K. W. W. Sims and J. Schwieters, Journal of Analytical Atomic Spectrometry, 2008, 23(2), 173-180.

447 D. Upadhyay, E. E. Scherer and K. Mezger, Journal of Analytical Atomic Spectrometry, 2008, 23(4), 561-568.

448 C. F. Li, F. K. Chen and X. H. Li, International Journal of Mass Spectrometry, 2007, 266(1-3), 34-41.

449 A. Luguet, G. M. Nowell and D. G. Pearson, Chemical Geology, 2008, 248(34), 342-362.

450 M. D. Schmitz and B. Schoene, Geochemistry Geophysics Geosystems, 2007, 8.

451 K. Gopalan, J. D. Macdougall and C. Macisaac, Geostandards and Geoanalytical Research, 2007, 31(3), 227-236.

452 J. R. Bacon, K. L. Linge, R. R. Parrish and L. Van Vaeck, Journal of Analytical Atomic Spectrometry, 2008, 23(8), 1130-1162.

453 G. E. Bebout, B. D. Idleman, L. Li and A. Hilkert, Chem. Geol., 2007, 240(12), 1-10.

454 M. Bonifacie, N. Jendrzejewski, P. Agrinier, M. Coleman, F. Pineau and M. Javoy, Chem. Geol., 2007, 242(1-2), 187-201.

455 S. F. Crowley, H. J. Spero, D. A. Winter, H. J. Sloane and I. W. Croudace, Rapid Communications in Mass Spectrometry, 2008, 22(11), 1703-1713.

456 T. Ludwig and R. Stalder, Journal of Analytical Atomic Spectrometry, 2007, 22(11), 1415-1419.

457 M. Rosner, M. Wiedenbeck and T. Ludwig, Geostandards and Geoanalytical Research, 2008, 32(1), 27-38.

458 C. Rollion-Bard, N. Vigier and S. Spezzaferri, Chemical Geology, 2007, 244(3-4), 679-690.

459 N. Allison, A. A. Finch, J. M. Webster and D. A. Clague, Geochimica Et Cosmochimica Acta, 2007, 71(19), 4693-4703.

460 D. O. Breecker and Z. D. Sharp, American Mineralogist, 2007, 92(10), 15611572 .

461 K. M. Wilcken, T. T. Barrows, L. K. Fifield, S. G. Tims and P. Steier, Nucl. Instrum. Methods Phys. Res. Sect. B-Beam Interact. Mater. Atoms, 2007, 259(1), 727-732.

462 S. H. Lee, P. P. Povinec, E. Wyse and M. A. C. Hotchkis, Applied Radiation and Isotopes, 2008, 66(6-7), 823-828.

463 A. L. Hunt, G. A. Petrucci, P. R. Bierman and R. C. Finkel, Nucl. Instrum. Methods Phys. Res. Sect. B-Beam Interact. Mater. Atoms, 2007, 260(2), 633636.

464 C. Fitoussi and G. M. Raisbeck, Nucl. Instrum. Methods Phys. Res. Sect. BBeam Interact. Mater. Atoms, 2007, 259(1), 351-358.

465 S. Winkler, L. K. Fifield, S. G. Tims and C. R. Morton, Nucl. Instrum. Methods Phys. Res. Sect. B-Beam Interact. Mater. Atoms, 2007, 259(1), 256259. 
466 N. Craig, R. J. Speakman, R. S. Popelka-Filcoff, M. D. Glascock, J. D. Robertson, M. S. Shackley and M. S. Aldenderfer, Journal of Archaeological Science, 2007, 34(12), 2012-2024.

467 A. M. De Francesco, G. M. Crisci and M. Bocci, Archaeometry, 2008, 50, 337-350.

468 S. P. Lundblad, P. R. Mills and K. Hon, Archaeometry, 2008, 50, 1-11.

469 T. M. Shanahan, J. T. Overpeck, J. B. Hubeny, J. King, F. S. Hu, K. Hughen, G. Miller and J. Black, Geochemistry Geophysics Geosystems, 2008, 9.

470 M. Ziegler, T. Jilbert, G. J. de Lange, L. J. Lourens and G. J. Reichart, Geochemistry Geophysics Geosystems, 2008, 9.

471 M. A. Denecke, A. Somogyi, K. Janssens, R. Simon, K. Dardenne and U. Noseck, Microscopy and Microanalysis, 2007, 13(3), 165-172.

472 Y. Arai, M. K. Marcus, N. Tamura, J. A. Davis and J. M. Zachara, Environ. Sci. Technol., 2007, 41(13), 4633-4639.

473 T. Kogiso, K. Suzuki, T. Suzuki, K. Shinotsuka, K. Uesugi, A. Takeuchi and Y. Suzuki, Geochemistry Geophysics Geosystems, 2008, 9.

474 C. X. Wu, Y. Y. Huang, H. K. Li, C. R. Chen, W. He and K. F. Li, Petroleum Science, 2007, 4(3), 63-67.

475 P.G. Smith, I Koch, K. J. Reimer, Science of the Total Environment, 2008 390(1), 188-197.

476 L.Q. Chen, Y.F. Guo, L.M. Yang and Q.Q. Wang, Journal of Analytical Atomic Spectrometry, 2007, 22(11), 1403-1408.

477 Z.L. Chen, G. Owens, K.R. Kim, R. Naidu, Analytica Chemica Acta, 2007, 599(2), 163-169.

478 M.L. Chen, A.M. Zou, Y.L. Yu, R. H. Ye, Talanta, 2007, 73(4), 599-605. 